
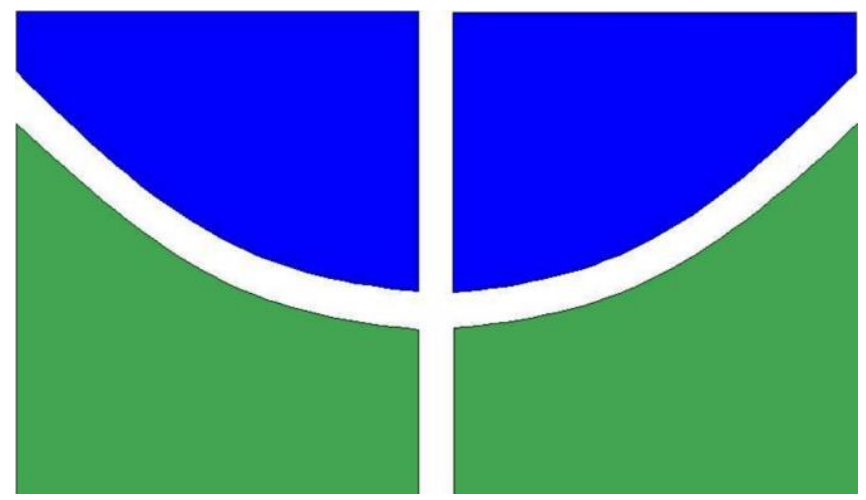

UNIVERSIDADE DE BRASÍLIA

INSTITUTO DE LETRAS

DEPARTAMENTO DE LINGUÍSTICA, PORTUGuÊS E LÍNGUAS CLÁSSICAS

PROGRAMA DE PÓS-GRADUAÇÃO EM LINGUÍSTICA

Representações do "Programa Mais Médicos" pelo site Pragmatismo Político e pelo Portal do Conselho Federal de Medicina

LEONARDO DE SOUZA

Bolsista Cnpq

BRASÍlIA - DF

DEZEMBRO/2014 


\section{Representações do "Programa Mais Médicos" pelo site Pragmatismo Político e pelo Portal do Conselho Federal de Medicina}

Dissertação apresentada ao Programa de Pós-Graduação em Linguística do Departamento de Linguística, Português e Línguas Clássicas, Instituto de Letras, Universidade de Brasília, como requisito parcial para a obtenção do Grau de Mestre em Linguística, área de concentração Linguagem e Sociedade.

Área de concentração: Linguagem e Sociedade.

Linha de Pesquisa: Discursos, Representações Sociais e Textos.

Orientadora: Prof. ${ }^{\text {a }}$ Dr.․ㅡ Viviane C. Vieira

$$
\begin{gathered}
\text { BRASÍLIA - DF } \\
\text { DEZEMBRO/2014 }
\end{gathered}
$$




\title{
Representações do "Programa Mais Médicos" pelo site Pragmatismo Político e pelo Portal do Conselho Federal de Medicina
}

\author{
LEONARDO DE SOUZA \\ Bolsista Cnpq
}

\begin{abstract}
Dissertação apresentada ao Programa de Pós-Graduação em Linguística do Departamento de Linguística, Português e Línguas Clássicas, Instituto de Letras, Universidade de Brasília, como requisito parcial para a obtenção do Grau de Mestre em Linguística, área de concentração Linguagem e Sociedade, defendida em à seguinte banca examinadora.
\end{abstract}

Profa. Dra. Viviane C. Vieira (UnB/PPGL) - Orientadora/Presidente

Profa. Dra. Dione Oliveira Moura (UnB/FAC) - Membro Efetivo Externo

Profa. Dra. Francisca Cordélia O. da Silva (UnB/PPGL) - Membro Efetivo Interno

Profa. Dra. Tatiana Rosa Nogueira Dias (UnB/LIP) - Membro Suplente

Brasília, 12 de dezembro de 2014. 
Dedico a todos que se sentirem peça dentro do jogo. 
Meus agradecimentos,

À professora Dra. Eni Abadia Batista, pelo incentivo e encorajamento para enfrentar essa batalha.

A todos/as os/as professores/as que fizeram parte dessa jornada.

À minha orientadora, professora Dra. Viviane C. Vieira, por aceitar me orientar sem me conhecer. Por compreender minhas dificuldades e me apoiar sem perder as esperanças. Pela paciência e boa vontade de me fazer crescer nos estudos e na vida pessoal.

À professora Dra. Juliana de Freitas Dias, pelas observações cuidadosas e conselhos passados na qualificação.

Ao Guga, amigo verdadeiro e sonhador dos mesmos sonhos.

Àqueles que no meio do caminho me encontraram e deixaram suas marcas. 
"O conhecimento e a ciência exigem trabalho, questionamentos sistemáticos e método." Descartes 


\section{RESUMO}

O presente estudo documental, qualitativo e sincrônico, tem como objetivo geral analisar criticamente discursos que circularam na mídia online, aqui representada pelo site Pragmatismo Político - e pelo Portal Médico, no contexto de proposição e implementação do Programa governamental Mais Médicos. Tendo como base teóricometodológica a Análise de Discurso Crítica (Chouliaraki \& Fairclough, 1999; Fairclough, 2003; Ramalho \& Resende, 2011; Resende \& Ramalho, 2006), para a qual o discurso é parte constitutiva do social, o estudo se propõe a pesquisar como o/a profissional médico/a de Cuba foi recebido/a e representado/a no discurso das mídias estudadas tendo em vista os interesses sociais e corporativos de cada uma. Realizamos análise de conjuntura social e análise das práticas particulares envolvidas na questão sociodiscursiva em foco, para, então, analisarmos um corpus documental principal composto por textos publicados pelo Portal Médico - veículo representante do Conselho Federal de Medicina - e outros textos publicados pelo site Pragmatismo Político, veículo independente que exerce o jornalismo colaborativo. Por meio de análises baseadas em categorias linguístico-discursivas como intertextualidade (Fairclough 2001), representação de atores sociais (van Leeuwen, 1998), além dos modos de operação da ideologia propostos em Thompson, (2011), refletimos sobre as diferentes representações e identificações dos/as médicos/as cubanos/as bem como do Programa Mais Médicos. Os resultados desta pesquisa parcial apontam que as representações dos/as médicos/as do Programa por parte do Portal Médico são discriminatórias, havendo uma exaltação dos/as profissionais da saúde brasileiros/as ao passo que se manifesta a desqualificação dos/as profissionais da saúde estrangeiros/as. Em relação aos/às médicos/as estrangeiros/as, nota-se, especificamente, uma mudança discursiva em relação à aceitação dos/as médicos/as cubanos/as, à medida que o programa se consolida, pois a população atendida defende a permanência desses profissionais.

Palavras-chave: discurso; médico; comunicação; ideologia; representação 


\begin{abstract}
ABSTRACT: This documentary, qualitative and synchronic study has the general objective critically analyze speeches that circulated on online media, represented here by the site - Political Pragmatism - and the Physician Portal, in the context of proposal and implementation of the government program More Doctors. As theoretical and methodological basis to Critical Discourse Analysis (Chouliaraki \& Fairclough, 1999; Fairclough, 2003; Ramalho \& Resende, 2011; Resende \& Ramalho, 2006), for which the discourse is constitutive of the social, the study aims researching how the cuban's doctor was received and represented in the discourse of media studied in view of the social and corporate interests of each. We conduct social situation analysis and analysis of the particular practices involved in sociodiscursiva issue at hand, to then analyze a major documentary corpus of texts published by the Medical Portal - representative vehicle of the Federal Council of Medicine - and other texts published by the Political Pragmatism site independent vehicle pursuing collaborative journalism. Through analysis based on linguistic and discursive categories as intertextuality (Fairclough 2001), representation of social actors (van Leeuwen, 1998) in addition to the modes of operation of the proposed ideology in Thompson, (2011), we reflect on the different representations and identifications of the cuban's doctor as well as the Program More Doctors. The results of this study indicate that partial representations of the medical program through the Physician Portal are discriminatory, with an exaltation of professionals in the Brazilian health while manifesting the disqualification of foreign health professionals. Regarding foreign doctors, there is specifically a discursive shift from the acceptance of Cuban doctors, as the program is consolidated, as the population served defends the permanence of these professionals.
\end{abstract}

Keywords: identity; doctor; media; ideology; representation 
Lista de Quadros

Quadro 1 - Aspectos da transmissão cultural ....................................................... 29

Quadro 2 - Relação de estruturação social e discursiva .............................................. 37

Quadro 3 - Categorias de representação de atores sociais ........................................... 50

Quadro 4 - Modos de operação da ideologia .................................................................... 54

Quadro 5 - Um ano de "Mais Médicos" no Portal Médico .......................................... 61

Quadro 6 - Um ano de "Mais Médicos" no Pragmatismo Político ............................. 63

Quadro 7 - Arcabouço teórico-metodológico da ADC ...................................................... 70

Quadro 8 - Quadro-resumodo corpus principal da pesquisa ........................................ 74

Quadro 9 - Quadro-resumo do corpus ampliado .............................................................. 76

Quadro 10 - Demonstrativo de textos que representam especificamente os/as médicos/as cubanos/as .................................................................................... 134 
Lista de Figuras

Figura 1 - Texto 1 - CRMs vão ter nomes de quem supervisiona o mais

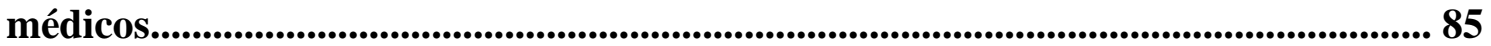

Figura 2 - Texto 2 - Conselho Federal de Medicina reitera apoio ao projeto

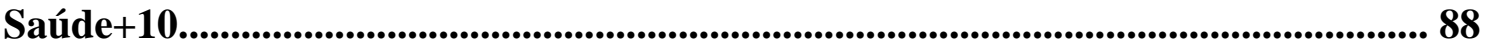

Figura 3 - Texto 3 - CFM denuncia ameaça à formação médica por políticas públicas................................................................................................................................................. 91

Figura 4 - Texto 4 - APM repudia improvisos apresentados pelo governo federal como remédio para o SUS............................................................................................. 95

Figura 5 - Texto 5 - Manifestação do CRM-PR em resposta ao plano "Mais Médicos", do governo federal.................................................................................... 98

Figura 6 - Texto 6 - Cremego, AMG e Simego criticam Programa Mais

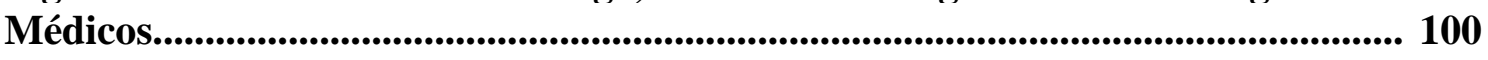

Figura 7 - Texto 7 - Mais Médicos, urgente! ........................................................................................................ 103

Figura 8 - Texto 8 - Globo é obrigada a reconhecer qualidade dos médicos

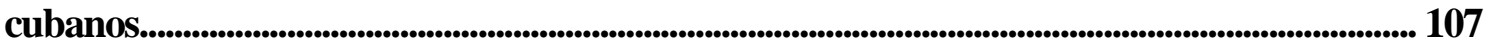

Figura 9 - Texto 9 - Médica cubana conclui seu plano e consegue asilo nos EUA ........... 110

Figura 10 - Texto 10 - "Escravidão?" $O$ povo quer mais médicos e menos

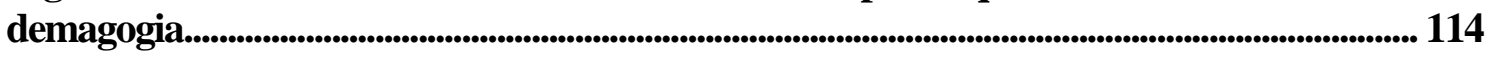

Figura 11 - Texto 11 - Servidores recebem extra e dinheiro do taxi para participar de protesto médico

Figura 12 - Texto 12 - Medicina é profissão com maior salário e menos profissionais. 
Sumário

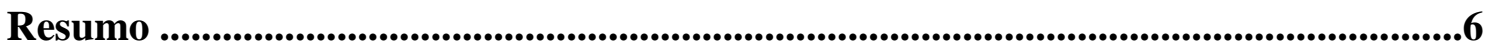

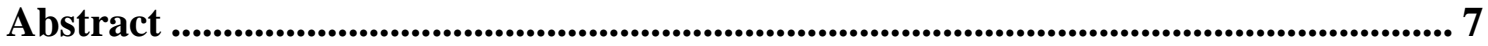

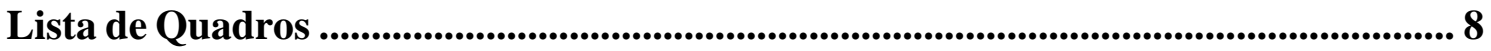

Lista de Figuras .............................................................................................................. 9

APRESENTAÇÃO

CAPÍTULO 1 - O PROGRAMA MAIS MÉDICOS ......................................................... 15

1.1 - Inspiração da pesquisa ........................................................................................15

1.1.1 - Cenário brasileiro ....................................................................18

1.2 - Mais Médicos como problematização de estudo em ADC ......................21

1.3 - Análise das práticas particulares de cada veículo ......................................26

1.3.1 - Sobre o portal colaborativo Pragmatismo Político ............................ 30

1.3.2 - Sobre o Conselho Federal de Medicina .............................................32

CAPÍTULO 2 - FUNDAMENTOS TEÓRICOS DA PESQUISA.............................. 35

2.1 - Principais conceitos em Análise de Discurso Crítica ............................. 35

2.2 - Significados do discurso ........................................................................43

2.2.1 - Significado identificacional e estilo ..............................................44

2.2.2 - Significado representacional e discurso .......................................47

2.2.3 - Significado (inter)acional e gênero ................................................50

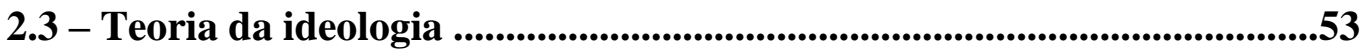

2.4 - Teorias de comunicação ...................................................................57

CAPÍTULO 3 - TEORIAS E METODOLOGIAS DE PESQUISA ....................... 68

3.1 - Abordagem teórico-metodológica .....................................................................68

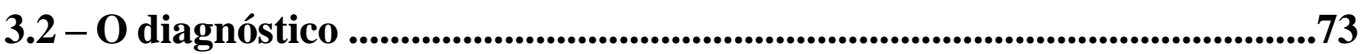

3.3 - Os pacientes ..............................................................................................

3.4 - As categorias linguístico discursivas de análise ......................................76

3.4.1 - Intertextualidade ..........................................................................76

3.4.1.1 - Intertextualidade manifesta .......................................................78

3.4.1.2 - Interdiscursividades ...............................................................80

3.4.1.3 - Representação de atores sociais .................................................. 81 
4.1 - Texto 1 - CRMs vão ter nomes de quem supervisiona o mais médicos .85

4.2 - Texto 2 - Conselho Federal de Medicina reitera apoio ao projeto Saúde+10 88

4.3 - Texto 3 - CFM denuncia ameaça à formação médica por políticas públicas

4.4 - Texto 4 - APM repudia improvisos apresentados pelo governo federal como remédio para o SUS .......................................................................... 95

4.5 - Texto 5 - Manifestação do CRM-PR em resposta ao plano "Mais Médicos", do governo federal .............................................................................. 98

4.6 - Texto 6 - Cremego, AMG e Simego criticam Programa Mais Médicos

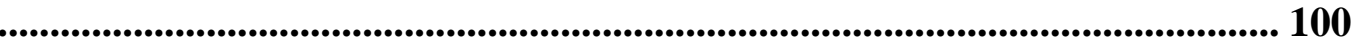

4.7 - Texto 7 - Mais Médicos, urgente! .............................................................. 103

4.8 - Texto 8 - Globo é obrigada a reconhecer qualidade dos médicos cubanos 107

4.9 - Texto 9 - Médica cubana conclui seu plano e consegue asilo nos EUA 110

4.10 - Texto 10 - "Escravidão?" O povo quer mais médicos e menos demagogia............................................................................................................................... 114

4.11 - Texto 11 - Servidores recebem extra e dinheiro do taxi para participar de protesto médico .................................................................................................... 119

4.12 - Texto 12 - Medicina é profissão com maior salário e menos profissionais 


\section{APRESENTAÇÃO}

Esta pesquisa é parte das atividades desenvolvidas no projeto "Gêneros discursivos, representações e identidades nas mídias", coordenado pela Profa. Dra. Viviane C. Vieira (RAMALHO, 2010, 2011, 2012, 2013a, 2013b; RESENDE \& RAMALHO, 2013; RAMALHO \& RESENDE, 2011). A proposta é problematizar discursos sobre o Progrma Mais Médicos, bem como dos/as médicos/as que atuam no Brasil, na mídia online, refletindo sobre as representações sociais que os sentidos de tais discursos podem desencadear. Neste estudo específico, de minha autoria, investigo representações sobre o Programa Mais Médicos no site Pragmatismo Político e no Portal Médico, buscando enfocar os discursos sobre o atual exercício, por diferentes atores sociais, da Medicina no Brasil.

Os objetivos da pesquisa são:

(1) analisar as representações sobre o Programa Mais Médicos nos veículos on line selecionados;

(2) identificar ideologias sobre o exercício da Medicina e

(3) refletir sobre as práticas sociais médicas e o discurso capitalista neoliberal, que tende a conceber a Medicina como um bem de consumo.

Este trabalho visa incentivar a reflexão sobre as contribuições das teorias da Análise de Discurso Crítica (ADC) e teorias de Comunicação para uma investigação sobre relações sociais desenvolvidas e mantidas por meio da linguagem. Proponho, portanto, um estudo transdisciplinar entre as teorias da ADC em diálogo com a Comunicação, permeadas por estudos sobre a ideologia.

A princípio, parto da observação de que algumas assimetrias de poder são estabelecidas e sustentadas nos discursos representados por alguns meios de comunicação, neste caso, referentes ao programa em questão. Dessa forma, selecionei dois veículos específicos a fim de investigar opções que cada um faz ao representar o social, pois seus discursos realçados no contexto da contratação de médicos/as estrangeiros/as pelo governo brasileiro, caracterizam-se como objeto de estudo relevante para a ADC, assim como emergem tendo destacável potencial de colaboração para estudos sociais de outras áreas do conhecimento. 
O que estimulou esta pesquisa foi a percepção da importância da Linguística, em especial da Análise de Discurso Crítica, para estudos em Comunicação. Minha trajetória acadêmica, que se iniciou no jornalismo, me aproximou dos estudos da linguagem na busca de ser um melhor profissional de comunicação e pesquisador combatente de injustiças sociais. Percebo que as disparidades impostas pelo sistema capitalista e a busca da satisfação individual cada vez mais impregnadas nos comportamentos sociais condicionam o indivíduo a observar apenas o seu microcosmos de atuação, enquanto se distancia do equilíbrio dos aspectos coletivos da vida em sociedade.

Tendo como base teórico-metodológica a Análise de Discurso Crítica (Chouliaraki \& Fairclough, 1999; Fairclough, 2003; Ramalho \& Resende, 2011; Resende \& Ramalho, 2013), este estudo investiga como o/a profissional de Cuba é recebido/a e representado/a no discurso das mídias em estudo, tendo em vista os interesses sociais e corporativos de cada uma.

Por meio de análises baseadas nas categorias linguístico-discursivas da ADC (Fairclough, 2001), em categorias de representação de atores sociais (van Leeuwen, 1998) e modos de operação da ideologia (Thompson, 2011), proponho reflexões sobre escolhas linguístico-discursivas que são feitas para representar e identificar atores ou grupos de atores e os efeitos potenciais de sentido dessas escolhas. Considerando que a análise textual é apenas uma etapa da análise de discurso, selecionei para análise seis textos publicados pelo Portal Médico e outros seis pelo site Pragmatismo Político, que, a partir da análise da conjuntura social de criação/implantação do Programa Mais Médicos e das práticas sociais particulares envolvidas na problemática em estudo, nos fornecerão material suficiente para perceber as diferentes formas de agir no mundo e representá-lo. Com essa base teórica e pesquisas pontuais em outros materiais de interesse, busco responder às seguintes perguntas para alcançar meus objetivos:

Como os/as médicos/as brasileiros/as são representados/as nos textos?

Como são representados/as os/as médicos/as cubanos/as?

E os/as de outras nacionalidades?

Que vozes e discursos são articulados nos textos?

Tais discursos têm potencial para manter relações de poder assimétricas?

Houve mudança discursiva do início para o fim do período analisado?

Apenas os/as médicos/as cubanos/as são criticados/as ou se criticam médicos/as de outras nacionalidades? 
No primeiro capítulo apresentarei o problema de pesquisa conforme propõe o arcabouço teórico-metodológico da ADC. Serão feitas a análise da conjuntura e das práticas particulares de cada veículo a fim de compreendermos o contexto social, político, histórico em que emerge a problematização da pesquisa. Na Seção 1 abordarei aspectos da conjuntura social brasileira no momento de início da pesquisa e as influências de diversas esferas sociais na conformação e desdobramento das questões de pesquisa aqui trabalhadas. Na Seção 2, apresentarei os principais conceitos da ADC e suas relações com o estudo em questão.

No segundo capítulo trabalharei as teorias que embasam este estudo. Iniciarei apresentando os principais conceitos em ADC. Na sequência explanarei os significados do discurso nesta ordem: significado identificacional e estilo, significado representacional e discurso e significado (inter)acional e gênero. Mais adiante, farei abordagens sobre a Teoria da Ideologia, seguida de Teorias da Comunicação, para finalizar com uma triangulação teórica entre a ADC e as duas anteriormente citadas.

O terceiro capítulo se constituirá de uma apresentação detalhada dos procedimentos metodológicos realizados para o alcance dos objetivos propostos. Da seleção do tema a ser investigado à definição de um material empírico específico, cada etapa será apresentada, a fim de detalhar o desenho da pesquisa. Portanto, iniciarei explorando o arcabouço teórico-metodológico proposto pela ADC. Na sequência revelarei algumas motivações para a execução da pesquisa assim como definirei o material empírico a ser utilizado. Por fim, encerrarei o capítulo com explicações sobre as categorias linguístico-discursivas de análise selecionadas para aplicação e obtenção dos resultados.

No quarto capítulo serão feitas as análises dos dados gerados e coletados. Neste capítulo analisarei os 12 textos do corpus principal. Nesta fase, serão investigadas categorias linguístico-discursivas como intertextualidade, interdiscursividade, representação de atores sociais e recursos de legitimação capazes de colocar em operação sentidos potencialmente ideológicos, com base em Fairclough (2001), van Leeuwen (1997) e Thompson (2011).

Por fim, na última parte, tecerei Considerações Finais sobre a pesquisa, em que retomarei e responderei às perguntas que motivaram o estudo. 


\section{CAPÍTULO 1 - O PROGRAMA 'MAIS MÉDICOS'}

Neste capítulo, abordo a conjuntura social, política e econômica no momento de proposição e implementação do Programa Mais Médicos, apresentando a motivação da pesquisa e o cenário brasileiro que ensejou o estudo. Apresento também características que enquandram o programa como problematização de estudos em ADC, assim como faço a análise das práticas particulares de cada veículo pesquisado.

\section{1 - Inspiração da pesquisa}

Este estudo tem como principal incentivo a enorme produção de conteúdo no momento em que o Programa Mais Médicos foi lançado. Em um cenário de instabilidade política, o contexto efervescente trouxe o tema para o foco dos debates públicos, resultando em manifestações enérgicas de interesses particulares e disputas de poder. A quantidade de veículos explorando o assunto e a intensidade com que a pauta era abordada atraiu minha atenção para um estudo aprofundado dessa realidade.

Começo obeservando que as mudanças no campo político, econômico e cultural que nos últimos anos marcaram a História atingem também de forma contundente as relações entre a opinião pública, os governos e as empresas. Nesse universo, a imprensa desponta como canal responsável por grande parte dos conteúdos que influenciam o comportamento e as atitudes do público.

Ignorar o papel da imprensa é fechar os olhos para uma evidência. Empresas e entidades públicas não conseguem cumprir bem sua missão se simplesmente resolvem desconhecer a importância da mídia no nosso cotidiano. Ela tanto pode ser uma aliada na construção da imagem, como um obstáculo para empresas e órgãos públicos atuarem no mercado ou cumprirem o seu papel.

A imprensa, em qualquer lugar do mundo, representa um poder que está sempre vigilante na divulgação do inusitado, do novo, do relevante, enfim, do que pode se transformar em notícia. Quando apenas reproduz aquilo que os grupos dominantes querem, ela deixa de cumprir seu papel social e se transforma tão-somente em porta-voz dos poderosos. Tem, portanto, uma face controversa, conflitante e difícil.

Entretanto, o crescimento da internet e de outras mídias em rede possibilitaram um novo cenário político no qual a distância é irrelevante e no qual estão sempre presentes a comunicação instantânea e a possibilidade de superar oponentes. Com isso, as interações sociais se transformaram e a esfera pública se ampliou em um espaço mais 
democrático de discussão, o que possibilitou a articulação de vozes antes abafadas pela incapacidade de alcançar um público indeterminado e ter um fim aberto. Ou seja, aumentou-se o fluxo de conteúdo nas redes de comunicação e permitiu-se que um número maior de indivíduos criasse e disseminasse esse conteúdo. Assim, como observa Thompson (2008, p. 16):

As mídias comunicacionais não se restringem aos aparatos técnicos usados para transmitir informações de um indivíduo a outro enquanto a relação entre eles permanece inalterada; ao contrário, usando as mídias comunicacionais <<novas〉> formas de agir e interagir são criadas considerando-se suas propriedades distintivas específicas.

Desde o surgimento da imprensa, os líderes políticos perceberam a impossibilidade de controlar inteiramente o novo tipo de visibilidade que a mídia possibilitava e deixá-la compatível com seus interesses. Agora, com o advento da internet e de outras tecnologias, isso ficou mais difícil do que nunca.

E uma das questões cruciais na concepção da imprensa é justamente a natureza da notícia e sua finalidade. Os meios colocam à disposição do público amplo material, permeado por distintas concepções do que seja notícia. Alguns veículos encaram a notícia como serviço público a ser prestado à sociedade, outros embalam a informação como mercadoria e há aqueles que a tratam como puro entretenimento. Nesse conjunto de possibilidades, cada veículo direciona as informações para os significados que mais atendem suas demandas. E a subjetividade se revela na medida em que tais demandas são atendidas pelos "produtores" de notícias.

O assunto da objetividade no jornalismo está aparentemente esgotado, ou, se não, encoberto pelos interesses corporativos. Não apenas a seleção de conteúdo reflete aspectos de subjetividade. O direcionamento da informação é a maior expressão da posição de sujeito. Sobre a objetividade no jornalismo, Pereira Junior (2006) reflete:

Gente do ramo acredita que encarar a objetividade como ilusão não passa de um tiro no pé da própria atividade jornalística. Quem enxerga as quimeras do imaginário industrial acredita que a objetividade não passa de camuflagem - avalista que é das manipulações de praxe dos mandarins da imprensa. (PEREIRA JUNIOR: 2006, p. 47) 
$\mathrm{Na}$ era empresarial em que vivemos, o produto jornalístico recebe influências de forças sociais, econômicas, políticas e psicológicas que transformam suas rotinas produtivas. Uma das principais é o alto custo de produção de um periódico. O gasto com tecnologia, por exemplo, exige dos jornais uma capacidade impensável de se obter receitas. A tendência é que a notícia se transforme em um produto rentável. Segundo Pereira Junior (2006), o sensacionalismo surge dessa demanda. O comércio da informação faz da notícia uma forma de alimentar carências de massa e vende na manchete fatos que a imprensa "respeitável" costuma subvalorizar.

No caso do Programa Mais Médicos, por exemplo, o desligamento intencional de um/a médico/a cubano/a é representado como uma subversão ao sistema de contratação e realçado como ato de protesto contra uma política de saúde pública defeituosa e injusta com os/as profissionais que nela atuam. Ao mesmo tempo, milhões de outros/as profissionais têm suas vozes abafadas enquanto fazem greve na luta por mais direitos e reconhecimento profissional. Percebemos, então, que o realce dado a um fato constitui verdadeiramente a intenção de representar o mundo da forma que melhor convém a quem se manifesta.

Todo esse quadro é permeado por antigas críticas e novas preocupações. Muitos setores da sociedade queixam-se dos monopólios da informação, porque poucas e poderosas empresas atuam com desenvoltura na esfera pública. Também com frequência ouvem-se críticas sobre manipulação, controle, predomínio de interesses políticoeconômicos e baixa qualidade dos produtos informativos e culturais.

É conforme essas características atuais da produção e reprodução de conteúdo pela imprensa brasileira, suas implicações na formação de opinião e, principalmente, sua contribuição para a manutenção de severas assimetrias de poder, que este capítulo se preocupa em oferecer subsídios teóricos afim de tornar clara a importância da Análise de Discurso Crítica (Chouliaraki \& Fairclough, 1999; Fairclough, 2001 e 2003) juntamente com Teorias de Comunicação (Wolf, 2003) para problematizarmos a questão social de pesquisa aqui delimitada.

O problema a partir do qual essa pesquisa se desenvolve é a forma como o Programa Mais Médicos foi recebido/discutido/combatido por determinados grupos de prestígio. A partir dessa reflexão, analisarei os modos de representação dos atores sociais compreendidos nos eventos recortados. A partir das formulações de van Leeuwen (1997), tomarei como principais fontes a serem investigadas a mídia e a classe médica. Portanto, trata-se de uma investigação sobre a abordagem dos meios de comunicação e o 
posicionamento dos/as médicos/as brasileiros/as frente possíveis transformações sociais previstas com a implementação do programa.

Mas não só em teóricos da ADC este trabalho se ampara. Buscando a maior compreensão dos fenômenos midiáticos, será imprescindível resgatar teóricos da Comunicação com suas formulações sobre os efeitos dos meios de comunicação de massa e todas as implicações decorrentes dessa pesquisa, a exemplo de Mauro Wolf (2003), Maurice Mouillaud (1997) e John B. Thompson (2011).

\subsection{1 - Cenário Brasileiro}

No último biênio de 2013-2014 ocorreram no Brasil volumosas manifestações que sinalizaram o acentuado descontentamento da população em diversos segmentos da vida social e política. Em um plano geral, questionava-se o recebimento da Copa do Mundo de Futebol e das Olimpíadas pelo Brasil. Em aspectos específicos, uma variedade de temas socialmente distintos disputou espaço nos debates públicos com tais eventos esportivos.

Foi nesse panorama que, desencadeados pela insatisfação com o aumento das tarifas do transporte público em São Paulo, no início de 2013, gritos de cidadania ecoaram pelo país e preencheram os espaços públicos com um conjunto de permanentes reivindicações populares. As ruas foram tomadas por cidadãos que pediam aos governantes mais compromisso e honestidade em suas atuações no papel de representantes do povo.

No embalo desses protestos, a saúde apareceu exercendo papel de destaque nos apelos por todo o país. Não é novidade o clamor da sociedade por um sistema de saúde de qualidade. A falta de profissionais e a consequente demora nos atendimentos são as queixas mais constantes. Nas cidades mais distantes dos grandes centros a crise é ainda mais intensa.

Para satisfazer em parte essa demanda e concretizar um planejamento iniciado anteriormente ao cenário de protestos, o Governo Federal lançou, em julho de 2013, o Programa Mais Médicos. Trata-se da contratação de médicos/as estrangeiros/as para preencherem vagas de trabalho recusadas por médicos/as brasileiros/as. De acordo com definição dada pelo Ministério da Saúde ${ }^{1}$, “o Programa Mais Médicos faz parte de um amplo pacto de melhoria do atendimento aos usuários do Sistema Único de Saúde, que

${ }^{1}$ http://portalsaude.saude.gov.br/index.php/cidadao/acoes-e-programas/mais-medicos 
prevê mais investimentos em infraestrutura dos hospitais e unidades de saúde, além de levar mais médicos para regiões onde há escassez e ausência de profissionais”.

Ainda de acordo com o Ministério, estão sendo feitas convocações de médicos/as para atuar na atenção básica de municípios com maior vulnerabilidade social e Distritos Sanitários Especiais Indígenas (DSEI), o que garantirá mais médicos/as para o Brasil e mais saúde para a população. A iniciativa prevê também a expansão do número de vagas de medicina e de residência médica, além do aprimoramento da formação médica no Brasil.

Criado por meio da Medida Provisória Nº 621, de 8 de julho de 2013, o programa surgiu com as seguintes propostas 2 :

I - diminuir a carência de médicos nas regiões prioritárias para o SUS, a fim de reduzir as desigualdades regionais na área da saúde;

II - fortalecer a prestação de serviços na atenção básica em saúde no País;

III - aprimorar a formação médica no País e proporcionar maior experiência no campo de prática médica durante o processo de formação;

IV - ampliar a inserção do médico em formação nas unidades de atendimento do SUS, desenvolvendo seu conhecimento sobre a realidade da saúde da população brasileira;

V - fortalecer a política de educação permanente com a integração ensinoserviço, por meio da atuação das instituições de educação superior na supervisão acadêmica das atividades desenvolvidas pelos médicos;

VI - promover a troca de conhecimentos e experiências entre profissionais da saúde brasileiros e médicos formados em instituições estrangeiras;

VII - aperfeiçoar médicos nas políticas públicas de saúde do País e na organização e funcionamento do SUS; e

VIII - estimular a realização de pesquisas aplicadas no SUS.

A polêmica estava lançada. Para a população que sofre com a dependência da saúde pública, foi positivo. Para a maioria dos médicos/as e opositores/as ao Governo, um drama. Decorre que esta contrariedade de posicionamentos em relação ao programa indica uma diversidade de interesses particulares que extrapolam o âmbito da prática

\footnotetext{
${ }^{2}$ http://www.planalto.gov.br/ccivil_03/_ato2011-2014/2013/mpv/mpv621.htm
} 
médica e estimulam um debate acerca das estruturas econômica, social e política brasileiras.

Como é possível perceber, as demonstrações mais recentes de insatisfação dos/as médicos/as com o Sistema Único de Saúde se fundiram a outras reivindicações e, portanto, o discurso médico no contexto do Programa Mais Médicos foi desalinhado para outro viés. Enquanto o Governo se esforça para oferecer atendimento médico de qualidade, a classe médica contraria, com argumentos desproporcionais, a implementação do programa.

Nesse contexto de insatisfações, o discurso neoliberalista se fortaleceu nas ruas e tentou-se firmar a fantasiosa impressão de que o comunismo estaria sendo implementado no Brasil. A criação do Programa Mais Médicos colaborou para a disseminação de um discurso que colocava o País como financiador da "ditadura comunista" cubana. Logo, as manifestações contra o programa também podem ser vistas como reflexos da luta eterna entre socialismo e capitalismo.

Tendo em vista essa emergente batalha, é sobre os enquadramentos da mídia e das instituições médicas que a presente pesquisa se volta para analisar o discurso da mídia online Pragmatismo Político e do Portal Médico no contexto do Programa Mais Médicos e problematizar representações, práticas sociais e identidades desses/as profissionais.

A proposta de estudar as práticas sociais que influenciam e são influenciadas pelos discursos da classe médica visa problematizar a manutenção de um posicionamento elitista evidenciado, entre outros aspectos, pela maneira como a Medicina está sendo mercantilizada na lógica de um bem de consumo não-durável.

A revolta dos/as médicos/as possivelmente se configurou em virtude de um sentimento de ameaça do status quo da Medicina brasileira. A vinda de médicos/as de outros países e a presumível implantação de outro paradigma nos cuidados com a saúde incomodou os/as profissionais brasileiros/as. De tal modo, eles/as não atacam o Programa Mais Médicos por suas incorreções, mas no afã de não permitirem interferências em suas práticas já consolidadas.

Notadamente, há uma grande diferença entre as medicinas cubana e brasileira. Enquanto aquela se desenvolve com ênfase na atenção primária à saúde ${ }^{3}$, a nossa voltase ao ensino especializado e de maior dependência tecnológica. Ou seja, nossos/as profissionais são formados/as para trabalhar em grandes centros médicos com estrutura

\footnotetext{
${ }^{3}$ http://www.epsjv.fiocruz.br/dicionario/verbetes/ateprisau.html
} 
sofisticada e tecnologias avançadas, enquanto os/as profissionais cubanos/as se formam para exercer uma Medicina de Atenção Primária e maior contato humano com os/as pacientes.

Portanto, essa prática cubana pode provocar uma mudança de paradigma no exercício da Medicina brasileira. O fato de aumentar o número de profissionais nas áreas mais carentes e disponibilizar atendimentos de atenção primária, naturalmente diminuirá os casos em que enfermidades de baixo potencial ofensivo evoluem para casos crônicos, da mesma forma que reduzirá outros índices como a mortalidade infantil, por exemplo.

Todavia, nos parece que a lógica da Medicina brasileira é fazer que a população seja dependente dos serviços médicos, ao ponto destes/as profissionais determinarem toda e qualquer acomodação da relação médico-paciente. Ao contrário, a Medicina cubana se empenha em evitar que o cidadão se transforme em "refém" dos hospitais através de campanhas de educação e acompanhamento constante e próximo de seus pacientes.

\section{2 - Programa Mais Médicos como problematização de estudo em ADC}

O Mais Médicos ${ }^{4}$, em suas diretrizes e objetivos, é um programa que foi elaborado pelo Governo Federal para amortecer carências públicas relativas à oferta de atendimento médico. Entretanto, em seu desenvolvimento e aplicação, diversas controvérsias e resistências insurgiram, o que pode ser analisado por um viés de conflitos ideológicos entre classes sociais.

A prática médica, em cada sociedade, em um dado momento, está baseada na concepção predominante do que seja o processo saúdedoença. Define-se pelas características e pelas relações socioeconômicas, políticas e ideológicas relacionadas com o saber teórico e prático sobre a doença, sobre a organização, administração e avaliação dos serviços de saúde, e sobre os usuários desses serviços. Nesse sentido, é fundamental compreender como se dão os mecanismos de determinação do perfil da atuação médica, uma vez que é mediante o confronto de interesses de diversas naturezas e de diferentes segmentos sociais que se determina o modo como se estrutura a atenção à saúde e a formação dos profissionais necessários para os serviços de saúde. (ADAM \& HERZLICH, 2001, p. 59)

\footnotetext{
${ }^{4}$ http://portalsaude.saude.gov.br/index.php/cidadao/acoes-e-programas/mais-medicos
} 
É acerca desses interesses múltiplos, relacionados ao sistema de saúde brasileiro, que aprofundarei as discussões propostas por esta dissertação. É exatamente o entendimento dos mecanismos utilizados por cada segmento social na defesa de seus interesses, o que se busca proporcionar através da análise de discurso linguisticamente orientada que este trabalho desenvolve.

O que é de maior significação aqui para a análise do discurso é a visão de discurso como constitutiva - contribuindo para a produção, a transformação e a reprodução dos objetos da vida social. Isso implica que o discurso tem uma relação ativa com a realidade, que a linguagem significa a realidade no sentido da construção de significados para ela, em vez de o discurso ter uma relação passiva com a realidade, com a linguagem meramente se referindo aos objetos, os quais são tidos como dados na realidade. (FAIRCLOUGH, 2001, p. 66)

As diferentes abordagens do Governo, da mídia e dos/as médicos/as sobre o Programa Mais Médicos representam palco próspero para estudos em ADC a fim explorar as relações entre discurso e poder social. Mais especificamente, descrever e explicar como o abuso do poder pode ser praticado, reproduzido e legitimado pelo texto e pelo discurso de grupos ou instituições dominantes.

Analisar a atuação médica em um país, ao longo do tempo, é também estudar o processo de reforma e mudança do sistema de saúde nacional, dentro de um quadro mais geral. Para compreensão e discussão do seu processo de mudanças, devemos considerar a influência do mercado de trabalho e a incorporação de recursos tecnológicos cada vez mais avançados na prática médica. Ora, observar sua constante evolução e transformação, conhecer e compreender a dinâmica dessa permanente mudança, seria o mesmo que se dispor a estudar a própria história de um povo.

Nesta perspectiva, optei pela ADC como abordagem científica capaz de viabilizar este estudo baseado principalmente nas relações dialéticas entre linguagem e sociedade. Ou seja, de alguma forma conseguimos relacionar propriedades típicas da escrita, da fala, da interação e das práticas semióticas a aspectos típicos da sociedade como grupos, organizações ou outras coletividades e suas relações de dominação.

Retomando um dos objetivos do Mais Médicos, devemos lembrar que as convocações de médicos/as nacionais e estrangeiros/as são principalmente para atuação na atenção básica de municípios com maior vulnerabilidade social. Isso significa dizer que serão dadas a esses municípios oportunidades de atendimento primário e instruções 
para a prevenção ou tratamento de enfermidades com menor potencial danoso. Esta ação evitará que um número considerável de casos evolua para moléstias crônicas e necessitem compor as filas dos hospitais dos grandes centros. Além disso, pessoas portadoras de doenças incuráveis, que dependem na maior parte do tempo de cuidados permanentes e um contato regular com a Medicina, poderão ter sua saúde monitorada com mais facilidade. Como bem entendem Adam e Herzlich (2001):

\begin{abstract}
Nas sociedades industriais contemporâneas, a doença implica o contato com a Medicina. Consultar um médico e seguir suas prescrições é a atitude quase imediata de quem fica doente ou sente algo estranho com o organismo. Chega a ser uma obrigação moral: é necessário ser um 'bom paciente', ou seja, é preciso cuidar de si. (...) Os cuidados preventivos com o corpo, além de ser um direito, são também um dever. (ADAM \& HERZLICH, 2001, p. 31)
\end{abstract}

Mas para cumprir esse dever e exercer um direito é preciso haver condições. A primeira delas é que haja um/a profissional disponível para consultas. E o Programa Mais Médicos está tentando viabilizar esse/a profissional. É a solução para a saúde do País? É uma força a mais na direção de ampliar os serviços e garantir o exercício do direito à saúde. O que seria questionável é deixar uma grande parcela da população brasileira, que impossibilitada de alcançar um tratamento satisfatório, ou mesmo receber algum tratamento, permaneça obrigada a se amparar em práticas não convencionais de combate às doenças.

Ao avaliar $u^{5} a^{5}$ das diversas versões para o 'Juramento de Hipócrates 6 ', enxergamos que o/a médico/a promete, ao exercer a arte de curar, mostrar-se sempre fiel aos preceitos da honestidade, da caridade e da ciência. Então por que os/as médicos/as brasileiros/as são contra o Programa Mais Médicos? Essa tendência não foge aos princípios do juramento? Talvez a resposta para essas perguntas requeira uma breve incursão na história da Medicina ocidental.

Muito antes da conformação atual da profissão, a doença era tida como um mal incontornável. A superação dessa noção e o desenvolvimento da Medicina científica, destacou a saúde como um dos valores mais importantes na sociedade, entusiasmando a criação de leis que assegurassem a cada um o direito aos tratamentos. Aos poucos, a doença se afastou dos contornos de praga divina, redenção de pecados ou obra do destino,

\footnotetext{
${ }^{5}$ Versão adotada pela Faculdade de Medicina da Universidade Federal de Minas Gerais

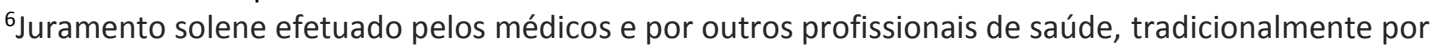
ocasião de sua formatura, no qual juram praticar a medicina honestamente.
} 
e assumiu a condição de evento hostil a ser combatido pelo homem. Todavia, a proximidade entre Medicina, magia e religião, característica das medicinas antigas, tanto eruditas quanto populares, ainda se preserva em todas as culturas. Além disso, a Medicina científica moderna não é "asséptica" de aspectos religiosos.

Considerado pelos/as médicos/as atuais o fundador da Medicina científica, Hipócrates recebeu essa honraria por iniciar a compreensão do ofício em função das observações realizadas sobre o estado do/a doente. Ainda assim, responsabilizava a vontade divina pela punição moral à sociedade na forma de determinadas moléstias, em particular as epidemias. Suas ideias predominaram por mais de um milênio.

Com a criação das universidades, no século XIII, o médico conquistou novo papel social. Era considerado um privilegiado por pertencer a uma universidade. Porém, seu prestígio continuou pequeno fora das grandes cidades. No século XVII, por exemplo, na ocasião da morte de reis e príncipes, o primeiro lugar junto à cabeceira do moribundo ainda era do sacerdote. E os médicos ainda travariam grandes lutas contra barbeiros e cirurgiões. A Medicina seguiu avançando, mas nem sempre os médicos foram os responsáveis pelas descobertas mais importantes.

No século XIX, a aproximação de médicos e cirurgiões e a prática sistemática da autópsia reposicionou a Medicina. A observação junto ao leito do paciente e o surgimento de novas técnicas de exame permitiram maior precisão nos diagnósticos. A descoberta de micro-organismos como os micróbios deram base às intuições sobre o contágio. Com as vacinas principalmente, mas também com o progresso da assepsia, a Medicina transpôs uma etapa decisiva em termos de eficácia e de conhecimento.

A descoberta dos raios-X, o desenvolvimento da anestesia, o tratamento com insulina para o diabetes, a descoberta das vitaminas e, mais tarde, a descoberta dos antibióticos proporcionou a sensação de um poderio ilimitado da Medicina. Esses fatores contribuíram também para a ascensão da Medicina à condição de profissão.

Como destacam Adam e Herzlich (2001, p.38), “durante um século, paralelamente ao seu desenvolvimento científico, a Medicina experimentou uma mudança decisiva em sua representação social". Os médicos passaram a imperar no campo da saúde. As outras atividades desenvolvidas, como a dos enfermeiros e fisioterapeutas, por exemplo, dependem deles diretamente e são consideradas categorias inferiores pelo senso comum. “A importância da Medicina decorre também do valor atribuído à saúde, à vida e à morte". (Ibidem, p.39) 
Para outros autores, "a conquista da condição de profissão, que se define essencialmente pelo privilégio da auto-regulamentação, representa sempre uma luta entre grupos rivais e constitui um processo de natureza política, passível de intervenção estatal” (Adam e Herzlich, 2001, p.40).

Ora, independente da razão preponderante para a ascensão da Medicina como profissão, dos embates levantados contra outras áreas da saúde e das conquistas até agora asseguradas, entendemos que seu processo de evolução foi calcado em batalhas para a preservação do domínio de certas atividades aliado a disputas políticas. O que ainda hoje se manifesta, por exemplo, com o Ato Médico ${ }^{7}$, polêmico projeto de lei que regulamenta o exercício da Medicina. Em suma, os questionamentos acerca de pontos específicos do referido projeto se opõem à extrema necessidade de estabelecer uma série de procedimentos como exclusivos de médicos/as diplomados/as.

Diante do panorama acima delineado, tudo leva a crer que os/as médicos/as brasileiros/as estão em confronto não só com seus/suas colegas estrangeiros/as, quando em seus discursos corporativistas e, por vezes, xenofóbicos, deixam escapar uma latente ambição pelo monopólio de certas práticas, conhecimentos e, consequentemente, mercados.

Porém, é justo ressaltar que não se trata de uma abordagem estritamente brasileira. A pesquisa histórica mostra que essa evolução foi complexa em todos os países ocidentais. Ainda assim, Adam e Herzlich(2001) esclarecem o que poderíamos tomar como alicerce para a compreensão da postura sustentada pelos médicos:

A mobilização dos médicos, sua luta coletiva é, portanto, também determinante: em cada circunstância, eles souberam valorizar, junto às elites e às camadas populares, o progresso de seu saber, a importância de seus serviços e apresenta-los como superiores aos dos concorrentes, conseguindo afastá-los ou reduzi-los a uma posição subordinada. Por fim, resta o papel do Estado: no final do século XIX, o interesse pela saúde da população o torna sensível às reivindicações dos médicos. Mas esse interesse, por sua vez, aumenta pela percepção de que o desenvolvimento médico e científico pode trazer respostas eficientes. (ADAM \& HERZLICH, 2001, p.41).

\footnotetext{
${ }^{7}$ http://legis.senado.gov.br/mateweb/arquivos/mate-pdf/130477.pdf
} 
Considerando a evolução da Medicina e as mudanças na concepção de saúde e doença, o que predomina hoje é um modelo capitalista no qual a saúde é vendida por preços elevados, isolando desse mercado as populações menos favorecidas.

Ao traçar um histórico dos "modelos explicativos do processo saúdedoença", Barros (2000) identifica, nos dias atuais, a predominância do paradigma "biomédico". Em poucas palavras, esse paradigma reduz o processo saúde-doença à dimensão biológica e prioriza um tipo de atenção segmentada em "especialidades médicas", que pressupõe uma visão do paciente "em partes". Esse modelo ocidental, a despeito de seu avanço e sofisticação, segundo o autor, já mostrou suas limitações. Por exemplo, por não oferecer respostas conclusivas ou satisfatórias para muitos problemas, sobretudo, "para os componentes psicológicos ou subjetivos que, em maior ou menor grau, acompanham as doenças". Tal modelo é entendido como hegemônico, uma opção, temporariamente vencedora, dentre tantas outras possíveis, e que expressa interesses de grupos particulares em sustentar o "complexo médico-industrial", ou a “empresa médico-hospitalar”. (BARROS 2000, apud RAMALHO 2008)

E esse modelo é sustentado também por meio de discursos que conformam práticas sociais. Portanto, cabe explorar as formas como cada ator participante dessa complexa rede de práticas exerce interferência na manutenção de interesses particulares. Sendo assim, na seção seguinte analisarei as práticas particulares dos veículos selecionados a fim de estabelecer relações entre elas e as consequências no mundo social.

\section{3 - Análise das práticas particulares dos veículos - Pragmatismo Político e Portal Médico}

No recente contexto de conflitos ideológicos entre poder público e profissionais da Medicina, faz-se indispensável este estudo crítico das representações discursivas disseminadas pelos meios de comunicação.

Devido à condição de prestígio demandada para a participação na produção de conteúdos simbólicos e considerando a relação dialética entre linguagem e sociedade, é possível identificar em discursos específicos a construção de sentidos que permitem estabelecer e sustentar relações de dominação.

Refletir sobre as variáveis que influenciam a produção, distribuição e consumo de determinados discursos faz parte da compreensão do problema sociodiscursivo que analiso nesta pesquisa. Assim, a análise das práticas particulares nos fornecerá apoio 
imprescindível para a realização de avaliações mais profundas acerca dos efeitos pretendidos pelos discursos focalizados. Conforme observa Thompson (2000):

\begin{abstract}
As formas simbólicas estão sempre inseridas em contextos sociais estruturados. A inserção destas em contextos sociais implica que, além de serem expressões de um sujeito, essas formas são, geralmente, produzidas por agentes situados dentro de um contexto sócio-histórico específico e dotados de recursos e capacidades de vários tipos; as formas simbólicas podem carregar os traços, de diferentes maneiras, das condições sociais de sua produção. (THOMPSON: 2000, p. 193)
\end{abstract}

Considerando esses aspectos mencionados sobre a produção de informações e “fabricação" de valores, serão analisados dois veículos não pertencentes à grande mídia hegemônica tradicional. O critério de seleção foi baseado na distinção entre dois representantes aparentemente responsáveis por juízos conflitantes sobre a implementação e funcionamento do Programa Mais Médicos. O Portal Médico representa o órgão máximo de defesa dos interesses da classe médica. O site Pragmatismo Político explora temas relativos a justiça social, cidadania e direitos humanos.

Enquanto o portal do Conselho Federal de Medicina divulga textos que, mesmo se não escritos por médicos/as, seguramente servem à defesa de seus interesses corporativos, o Pragmatismo Político dá voz a diversos segmentos sociais em suas múltiplas abordagens sobre a atuação médica, como as explanações iniciais já apontaram. Portanto, no contexto do Programa Mais Médicos, tais práticas indicam um embate entre os defensores e opositores ao programa.

Portanto, a seleção dos dois veículos teve tais motivações: o Portal Médico por ser defensor incondicional da classe médica, fazendo deste um veículo de assessoria dos/as médicos/as e suas instituições; e o Pragamatismo Político pela sua característica independente de interesses coprporativos e crescente destaque no cenário das mídias independentes brasileiras.

A escolha de um veículo não vinculado a uma coorporação em contraposição a um defensor de interesses corporativos se dá pela possibilidade de obter um material de análise mais revelador e compatível com os objetivos que aqui são perseguidos. Além disso, os sites selecionados não operam no mercado competitivo das notícias e, portanto, teoricamente não estão sujeitos a pressões financeiras e demais influências mercadológicas. 
Quando se pretende emitir opinião ou qualquer outra forma de expressão que atinja um público diversificado e abrangente, sabemos que são os meios de comunicação de massa os principais responsáveis por essa mediação. Logo, cada veículo ou instituição segue sua linha editorial ou ideário predominante. É o que esclarece van Dijk (2012) nos termos seguintes:

\begin{abstract}
Pessoas não são livres para falar ou escrever quando, onde, para quem, sobre o que ou como elas querem, mas são parcial ou totalmente controladas pelos outros poderosos, tais como o Estado, a polícia, a mídia ou uma empresa interessada na supressão da liberdade da escrita e da fala (tipicamente crítica). Ou, ao contrário, elas têm que falar ou escrever como são mandadas a falar ou escrever. (Van Dijk, 2012, p. 18)
\end{abstract}

Sendo mais específico em sua abordagem, Thompson (2011) levanta três aspectos particulares da transmissão de conteúdo pelos meios de comunicação. Primeiramente ele se refere aos meios técnicos de transmissão, ou seja, aos substratos materiais nos quais as mensagens serão produzidas e transmitidas. Esses meios técnicos podem ser avaliados segundo três características: o grau de fixação da forma simbólica (capacidade de estocagem de informação), o grau de reprodução da forma simbólica e a natureza e amplitude da participação dos indivíduos que utilizam certo meio.

De acordo com os aspectos estabelecidos por Thompson (2011), em segundo lugar, mais que o meio técnico, a troca de informações também envolve um mecanismo institucional de transmissão. São articulações caracterizadas por regras, recursos e relações de vários tipos; implicam relações hierárquicas de poder entre os indivíduos que ocupam as posições institucionalizadas. Portanto, tais aparatos institucionais são os responsáveis por limitar ou reorientar a difusão de informações.

O terceiro aspecto da transmissão de informações diz respeito ao distanciamento no espaço e no tempo. Cada meio técnico permite um distanciamento que é próprio de seu funcionamento. A internet, por exemplo, pode ser o meio que permite o maior distanciamento entre a mensagem e seu contexto de produção, tanto local quanto temporal. Sua capacidade de encurtar espaços e relativizar o tempo é uma das principais características que a torna uma inovação de base capaz de alterar estruturas sociais.

De acordo com as distinções de Thompson (2011) entre três aspectos básicos de transmissão cultural - o meio técnico, o aparato institucional e o distanciamento 
espaçotemporal - faremos a análise das práticas particulares de cada veículo nas subseções seguintes, basedas no quadro seguinte:

Quadro 1 - Aspectos da Transmissão Cultural

\begin{tabular}{|l|c|}
\hline MEIO TÉCNICO & Fixação \\
& Reprodução \\
& Participação \\
\hline APARATO INSTITUCIONAL & Canais de difusão seletiva \\
& Mecanismos para implementação restrita \\
\hline $\begin{array}{l}\text { DISTANCIAMENTO ESPAÇO } \\
\text { TEMPORAL }\end{array}$ & Extextos de copresença \\
\hline
\end{tabular}

Adaptado de Thompson (2011: p. 227)

De acordo com o quadro acima farei observações a respeito de cada aspecto da transmissão cultural realizada pelos meios de comunicação pesquisados. Esses vários aspectos e atributos estão combinados de maneira tal que formam modalidades específicas de transmissão cultural. Por exemplo, cada modalidade está baseada em certos meios técnicos que conferem às importantes formas simbólicas certos tipos de fixação e de reproduzibilidade.

Sobre o meio técnico explanarei três características: a fixação, ou seja, capacidade de permanência do conteúdo no tempo; a reprodução, que diz respeito às possibilidades de distribuição dos textos; e a participação, referente às formas de interação entre produtores e destinatários da informação.

Sobre o aparato institucional, abordarei os canais de difusão seletiva e os mecanismos para implementação restrita, ou seja, explicitarei aspectos da comunicação referentes ao potencial de seleção de um público específico e às maneiras pelas quais essa oferta de conteúdo pode se realizar.

Por fim, farei considerações sobre a possibilidade de distanciamento entre os produtores e receptores das mensagens, assim como do tempo que pode separar a produção e o consumo das referidas formas simbólicas. 


\subsection{1 - Sobre o portal colaborativo Pragmatismo Político}

Na definição de sua missão institucional, o Pragmatismo Político (PP) ${ }^{8}$ salienta que "somente a cidadania plena conduz à democracia. Não há outra forma de ser cidadão que não seja através da educação ideológica e política". De tal modo, percebemos a expressão de sentidos potencialmente ideológicos a fim de combater desigualdades e promover a justiça em todos aspectos da vida social. O PP, supostamente, não segue tendências partidárias, nem milita a favor de causas excludentes. Sua causa é o fortalecimento da democracia.

Pragmatismo Político é um portal colaborativo e várias pessoas escrevem para o site. Colunistas e colaboradores diretos produzem conteúdo original, e indiretos são parceiros de publicações. Ou seja, os diretos produzem conteúdo periodicamente para o site, enquanto os indiretos são responsáveis por conteúdos de outros veículos que são reproduzidos no Pragmatismo Político. A edição geral e de conteúdo é de Luis Soares, cientista político paraibano.. Ele enfoca seu site em política partidária, direitos humanos, políticas públicas e temas que estejam inseridos na esfera social. Todas as fontes estão postas no início ou no fim dos textos. A maioria delas com link de redirecionamento. Nos artigos de opinião constam os nomes dos respectivos autores. Quando não autorais, as publicações são de parceiros autorizados.

Originalmente, Luis Soares ${ }^{9}$ escrevia em fóruns e iniciou a página em 2009 para dividir textos com colegas e fomentar discussões. O conteúdo repercutia além dos amigos e parte era reproduzido em portais maiores. Atualmente, o site tem mais de 1 milhão de visitas únicas mensais e mais de 3 milhões de visualizações de páginas.

De acordo com Soares ${ }^{10}$, que cita o Ibope, a web é o meio de comunicação que mais cresce no Brasil, mas ainda está longe de aglutinar todo o seu potencial mercadológico. O governo aplica mais de $70 \%$ da verba publicitária em dez empresas de comunicação e milhares dividem os 30\% que restam, para não mencionar os que nada recebem.

Apesar de ter audiência equivalente a muitos desses veículos de comunicação que desfrutam dos investimentos publicitários dos governos (federal, estaduais ou

\footnotetext{
${ }^{8}$ www.pragmatismopolitico.com.br

${ }^{9}$ http://pragmatismopolitico.jusbrasil.com.br/

${ }^{10}$ http://www.pragmatismopolitico.com.br/2014/04/pragmatismo-politico-na-revista-locaweb.html
} 
municipais), Pragmatismo Político e outros sites e blogs com forte fluxo de tráfego consolidado não recebem incentivos.

\begin{abstract}
Reitero ${ }^{11}$ a importância de se debater o processo de descentralização da mídia no Brasil. A relevância dos blogs, que dia após dia adquirem caráter mais profissional e se tornam fontes de informações confiáveis e alternativas; o surgimento das redes sociais, que aceleram o processo de democratização da comunicação, fornecendo espaço para o confronto de ideias aberto e sem hierarquização. Toda essa nova conjuntura que visa horizontalizar a notícia, o debate, o entretenimento e a informação precisa ser mais valorizada em detrimento de conglomerados cujos interesses não vão além da manutenção dos monopólios históricos e ainda vigentes.
\end{abstract}

Sobre a sistematização do Pragmatismo Político, temos o seguinte: além de contar com profissionais de diversas áreas que escrevem periodicamente para o site, ele reproduz matérias de outros veículos que se filiam aos seus propósitos. No primeiro caso, os profissionais escrevem a respeito de algo que está em pauta nacionalmente ou até pautam outros veículos ao incitarem novas discussões. No segundo, o site apenas funciona como amplificador de vozes e opiniões já emitidas por outros veículos.

O PP divide suas pautas nos seguintes assuntos: Porões da Ditadura, Educação, Cultura, Eleições, Saúde e Mídia. Percebe-se que essa variedade de conteúdos contempla qualquer assunto imaginável. Se não pertencer às demais classificações, pode se encaixar no tema Mídia. Aliás, a principal atividade do PP é refletir sobre as diferentes visões de mundo encampadas pela mídia.

Se levarmos em consideração o meio técnico, o Pragmatismo Político se diferencia do Conselho Federal de Medicina apenas no aspecto da participação, pois a capacidade de estocar informações e os meios de reprodução são similares nos dois veículos. Ambos possuem interatividade com outras plataformas da web: Google, Facebook, Twiter etc. Porém, o PP se diferencia pela maior capacidade de participação do leitor. Além das características já citadas, o site permite a participação de usuários nos debates através de comentários publicados no mesmo endereço onde se hospeda a matéria.

Em relação ao aparato institucional podemos, então, distanciar os dois veículos pesquisados. Diferentemente do Conselho Federal de Medicina, o Pragmatismo Político fala para uma sociedade inteira. A seleção do conteúdo reflete o grau de importância

\footnotetext{
${ }^{11}$ http://www.pragmatismopolitico.com.br/2014/04/pragmatismo-politico-na-revista-locaweb.html
} 
coletiva do que se pretende expor. As pressões do Estado, empresas, veículos de comunicação ou qualquer outra instituição moderna não direcionam diretamente sua forma de se comunicar. Isso significa que não são utilizados muitos mecanismos para implementação restrita de formas simbólicas nos sistemas sociais. O acesso à informação é público e gratuito.

No que tange o distanciamento espaço-temporal, o PP guarda características específicas de um meio de comunicação digital. Sua capacidade de acessibilidade é global, assim como os contextos de produção de conteúdo. Portanto, trata-se de um veículo que não se limita a contextos de copresença para a produção/transmissão de conteúdo simbólico, principalmente no que diz respeito à gama de temas tratados por este site. Boa parte de seu conteúdo é formada por reflexões sobre aspectos do mundo, o que caracteriza a atemporalidade da produção.

Resumindo, o Pragmatismo Político é um veículo que produz conteúdo diversificado, trabalhando os vários gêneros textuais; editoriais, artigos de opinião, comentários, notícias e outros gêneros se transformam em conteúdo para o PP. Esse conteúdo pode ser discutido abertamente pelo público, ficando o debate à disposição dos leitores que o acessarem. Logo, o site permite um tipo de interação mediada que se consolida por meio da troca de mensagens por indivíduos ou grupos de indivíduos.

\subsection{2 - Sobre o Portal Médico, mídia online do Conselho Federal de Medicina}

No caso do Conselho Federal de Medicina, por sua vez, a missão é ocupar-se de temas que se acercam da profissão. Mais especificamente, o conteúdo publicado pelo portal é todo no sentido de valorizar a atividade médica e, consequentemente, destacar o profissional em um gradiente de importância das profissões. Assim diz o texto de apresentação da instituição:

O Conselho Federal de Medicina, $\mathrm{CFM}^{12}$, é um órgão que possui atribuições constitucionais de fiscalização e normatização da prática médica. Criado em 1951, sua competência inicial reduzia-se ao registro profissional do médico e à aplicação de sanções do Código de Ética Médica.

Nos últimos 50 anos, o Brasil e a categoria médica mudaram muito, e hoje, as atribuições e o alcance das ações deste órgão estão mais amplas, extrapolando a aplicação do Código de Ética Médica e a normatização da prática profissional.

\footnotetext{
${ }^{12}$ portal.cfm.org.br
} 
Atualmente, o Conselho Federal de Medicina exerce um papel político muito importante na sociedade, atuando na defesa da saúde da população e dos interesses da classe médica.

O órgão traz um belo histórico de luta em prol dos interesses da saúde e do bem estar do povo brasileiro, sempre voltado para a adoção de políticas de saúde dignas e competentes, que alcancem a sociedade indiscriminadamente.

Ao defender os interesses corporativos dos médicos, o CFM empenha-se em defender a boa prática médica, o exercício profissional ético e uma boa formação técnica e humanista, convicto de que a melhor defesa da medicina consiste na garantia de serviços médicos de qualidade para a população.

Além de zelar pelo desempenho ético da medicina e pelo bom conceito da profissão, o CFM organiza uma série de atividades e presta outros serviços aos médicos e à sociedade brasileira.

No início da apresentação sobressai uma característica legitimadora do CFM como instituição de prestígio social: a detenção de atribuições constitucionais para exercer suas atividades. Na sequência, menciona-se a ampliação do alcance de suas ações e ressalta a importância de seu papel político na sociedade. Por fim, mesmo tentando aparentar uma preocupação social, deixa clara a missão de defender os interesses corporativos dos/as médicos/as.

Segundo a definição ${ }^{13}$ do setor de imprensa responsável pela produção de conteúdo para o CFM, "a equipe redige notícias para o Portal Médico e para o jornal Medicina, além de atender pedidos de veículos de imprensa e colaborar com a formulação de estratégias de divulgação de temas de interesse do CFM, bem como de seus pareceres e resoluções".

Percebe-se que os textos publicados pelo Portal Médico são produzidos com objetivo de enrijecer os laços internos da classe médica e, dessa forma, preservar o poder hegemônico dos/as médicos/as nas atividades da saúde. O portal do CFM nitidamente tem como público principal os/as médicos/as. Mais do que isso, suas publicações excluem vozes que não façam parte de seus anseios coorporativos.

Analisando os aspectos básicos de transmissão cultural sugeridos por Thompson (2011), o que podemos destacar do portal do Conselho Federal de Medicina, em relação ao meio técnico de registro, é sua restrição da participação direta do leitor no debate do conteúdo explorado. Por não possuir um espaço para comentários, o site atua no modelo de um jornal impresso, onde o leitor possui apenas um elo de comunicação com a instituição. Não pode dar opinião, fazer críticas ou sugestões. As mensagens de leitores

\footnotetext{
${ }^{13} \mathrm{http} / / /$ portal.cfm.org.br/index.php?option=com_qcontacts\&view=contact\&id=5\&Itemid=93
} 
devem ser enviadas por um canal aberto pelo veículo, que as avaliará, respondendo-as ou não. De toda forma, esse conteúdo nunca será publicado, permanecendo sempre disponível em tela apenas a voz do Conselho Federal de Medicina.

O caráter de assessoria de imprensa e relações públicas do Portal Médico faz dele um veículo que subutiliza as ferramentas dispostas pela internet. O portal possibilita apenas o que Thompson (2008) chama de quase interação mediada. Esta interação se caracteriza basicamente por ser monológica, abrindo apenas uma via de comunicação de sentido único.

Segundo seu aparato institucional, o Portal Médico se caracteriza como um canal de difusão seletiva. Sua atuação é no sentido de expor apenas o lado positivo da instituição "Médicos". É o que podemos chamar de assessor de imprensa da classe médica. Ou seja, um ator social que utiliza mecanismos para a implementação restrita de conteúdos que satisfazem apenas um lado da relação existente entre médicos/as e pacientes.

Em relação ao distanciamento espaço-temporal, podemos fazer duas observações importantes acerca do Portal Médico. Primeiro, por tratar prioritariamente de temas referentes à medicina brasileira, avaliamos que o conteúdo muitas vezes pressupõe contextos de copresença para sua produção. Segundo, é possível pensar que, por mais que a internet proporcione uma extensão de acessibilidade global, a forma como o conteúdo é formatado provavelmente reduz seu alcance à classe médica brasileira.

Porém, não é surpresa que o portal atue dessa forma. Seu papel é garantir a unidade da corporação e defender os/as médicos/as em quelquer batalha que enfrentem. Esse é o papel de todo assesssor de imprensa ou relações públicas. Logo, podemos perceber que os principais textos do Portal Médico analisados aqui são artigos de opinião; em todos o CFM deixa claro seu posicionamento em relação ao Programa Mais Médicos e destaca seus principais argumentos. 


\section{CAPÍTULO 2 - FUNDAMENTOS TEÓRICOS DA PESQUISA}

Neste capítulo faço referências aos principais conceitos inscritos na Análise de Discurso Crítica. Em primeiro lugar abordo os conceitos gerais que embasaram o estudo para, em seguida, especificar aqueles que possuem maior relevância para o desenvolvimento da pesquisa. Assim, me detenho nos significados do discurso e, a partir deles, introduzo conceitos como identidade, discurso e gênero discursivo. $\mathrm{O}$ capítulo se encerra com uma explanação que atravessa a Teoria Crítica da Ideologia, relacionando-a com Teorias de Comunicação de Massa.

\section{1 - Principais conceitos em Análise de Discurso Crítica}

Com base na Análise de Discurso Crítica e em teorias sociais, investigarei como os textos analisados materializam práticas sociais e discursos dominantes, e são constituídos em torno de modos de operação da ideologia capazes de sustentar sentidos projetados por ideias hegemônicas. Nesta perspectiva, serão utilizados alguns métodos analíticos desenvolvidos pela ADC.

Para situar o leitor e apresentar o arcabouço teórico que alimenta esta pesquisa, optei por dar início respondendo ao seguinte questionamento: por que estudar o Programa Mais Médicos utilizando como principal referencial teórico a Análise de Discurso Crítica?

Segundo Chouliaraki e Fairclough (1999), “o objetivo da ADC é refletir sobre a mudança social contemporânea, as mudanças globais de larga escala e sobre as possíveis transformações em estruturas sociais já cristalizadas”. Com esta consideração, podemos compreender como se inicia uma pesquisa em ADC, nas seguintes palavras de Resende e Ramalho (2006, p. 36):

Toda análise em ADC parte da percepção de um problema que, em geral, baseia-se em relações de poder, na distribuição assimétrica de recursos materiais e simbólicos em práticas sociais, na naturalização de discursos particulares como sendo universais, dado o caráter crítico da teoria.

Segundo uma definição conceitual mais concisa, a ADC foi proposta e desenvolvida como abordagem teórico-metodológica para o estudo da linguagem nas sociedades contemporâneas. Ou seja, através dela, podemos mapear as conexões entre relações de poder e recursos linguísticos utilizados em textos. Nas palavras de Ramalho 
(2005: 23), "analistas críticos do discurso acreditam que a desconstrução ideológica de textos que integram práticas sociais pode intervir de algum modo na sociedade a fim de desvelar relações de dominação".

De tal modo, com recortes de matérias jornalísticas e outros textos referentes ao Programa Mais Médicos, pretendo empreender um conjunto de análises que servirão como referências para posicionar o leitor diante das representações e identificações dos/as médicos/as brasileiros/as e estrangeiros/as no contexto do programa.

Para satisfação dos objetivos da pesquisa, precisarei percorrer um caminho teórico-metodológico que atenda às necessidades de um/a pesquisador/a, ao mesmo tempo que seja de simples compreensão e apreensão dos/as leitores/as. Sendo assim, proponho apresentar de forma fracionada cada fundamento teórico a que farei referência para a confecção do produto final. Reafirmo que este trabalho tem como principal abordagem teórica os fundamentos da Análise de Discurso Crítica desenvolvida pelo linguista britânico Norman Fairclough.

Em geral, serão explorados conceitos como representação de atores sociais de Theo van Leeuwen (1998), modos de operação da ideologia segundo as formulações de John B. Thompson (2011), identidade na concepção de Stuart Hall (2006), além de categorias analíticas como intertextualidade e interdiscursividade trabalhadas por Fairclough (2001). Os esforços se guiarão também pelas perspectivas de autores como Teun van Dijk (2012) e Ruth Wodak, além de outras referências latino-americanas como Ramalho \& Resende $(2006,2011)$ - que introduziram novos olhares aos estudos da ADC.

Quando realizamos pesquisas baseadas na $\mathrm{ADC}$, é fundamental que tornemos nítida a relevância de alguns conceitos. Portanto, "discurso", "ideologia" e "poder como hegemonia" são noções preliminares que abordarei ao longo do trabalho, introduzindo gradativamente outros elementos da disciplina.

Inicialmente, tratarei o discurso esclarecendo algumas concepções utilizadas por autores consagrados no desenvolvimento da ADC como ferramenta para estudos sociais com ênfase na linguagem. E nada mais apropriado que iniciar esta apresentação me referindo ao grande expoente da vertente britânica da ADC, Norman Fairclough. Para Fairclough (2001, p. 21), “discurso é um conceito difícil, principalmente porque há tantas definições conflitantes e sobrepostas, formuladas de várias perspectivas teóricas e disciplinares". 
Sendo assim, como Fairclough (2003a, p. 26) prioriza, sobre o termo 'discurso' recaem dois significados. Como substantivo mais abstrato, significa 'linguagem como momento irredutível da vida social'. Por outro lado, como um substantivo mais concreto, discurso significa um 'modo particular de representar parte do mundo', ligado a interesses específicos. (Ramalho \& Resende, 2011, p. 17)

"Essa duplicidade de sentidos não compromete a compreensão aqui porque, para tratar da segunda acepção, mais concreta, falarei em discursos 'particulares' ou 'discursos', no plural”, conforme propõem (Ramalho \& Resende, 2011, p. 17). Aqui tratarei o "discurso como um modo de ação, uma forma em que as pessoas podem agir sobre o mundo e especialmente sobre os outros, como também um modo de representação" (FAIRCLOUGH, 2001, p.91). Portanto, temos o discurso como um momento das práticas sociais.

Nas palavras de Chouliaraki e Fairclough (1999, p. 21), práticas sociais são "maneiras recorrentes, situadas temporal e espacialmente, pelas quais agimos e interagimos no mundo". São entidades intermediadoras entre o potencial abstrato presente nas estruturas e a realização desse potencial em eventos concretos, assim como podemos visualizar no esquema seguinte.

Quadro 2 - Relação de estruturação social e discursiva

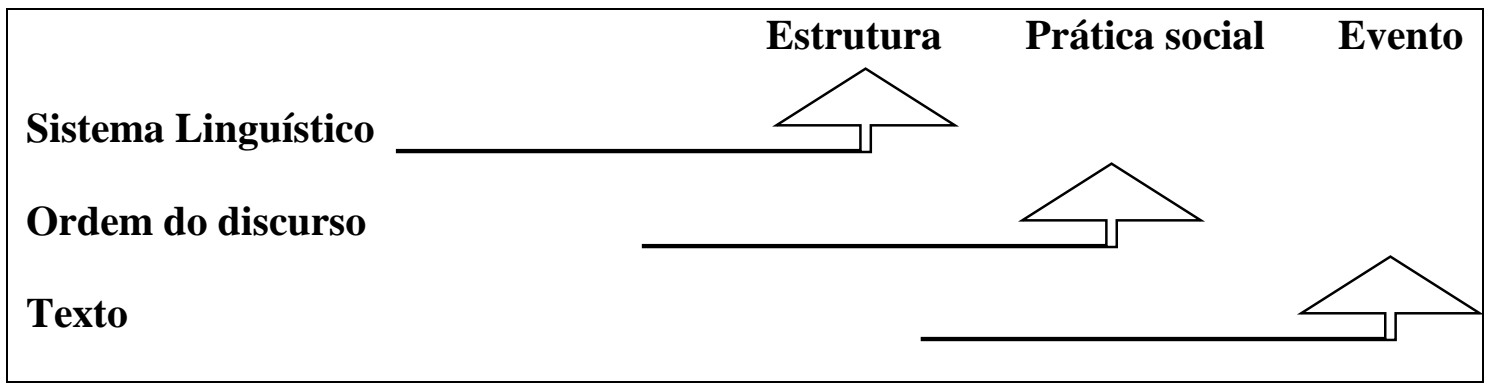

Adaptação de Ramalho e Resende (2011, p. 15)

O texto, material empírico de trabalho do/a analista do discurso, é a materialização do evento discursivo. Logo, é o texto que servirá de elemento para, por meio da análise linguística, investigarmos os aspectos do processo interacional dos atores sociais, ou seja, a prática discursiva.

A prática discursiva é a dimensão do uso da linguagem que envolve os processos sociocognitivos de produção, distribuição e consumo dos 
textos. O conceito de intertextualidade, "a propriedade que têm os textos de ser cheios de fragmentos de outros textos, que podem ser delimitados explicitamente ou mesclados e que o texto pode assimilar, contradizer, ecoar ironicamente e assim por diante" (FAIRCLOUGH, 2001: 114), viabiliza a compreensão das práticas discursivas existentes na sociedade e a relação entre elas.(RAMALHO, 2005, p. 24)

A análise da prática discursiva nos fornecerá elementos para melhor compreensão das circunstâncias organizacionais e institucionais da sociedade, ou seja, as práticas sociais. Estas, funcionam como ponte entre as estruturas sociais e os eventos manifestos.

Para Fairclough (2003), o discurso é um modo de ação, uma prática que altera o mundo e altera os outros indivíduos no mundo. Ele explica que discursos não são apenas representações do mundo come ele é, são também projeções, imaginações, representações de mundos possíveis diferentes do mundo atual. Estão relacionados com projetos de mudanças no mundo segundo diferentes perspectivas, pois as relações entre diferentes discursos são elementos dos relacionamentos entre diferentes pessoas. Desse modo, a ADC fundamenta pesquisas que exerçam ações de contra poder e contra ideologia, práticas de resistência à opressão social.

Por exemplo, quando a classe médica brasileira sustenta que no Brasil não faltam médicos/as, ela está representando uma situação que não é real. A população das áreas desprovidas de atendimento fala exatamente o contrário. A interação entre esses dois discursos representa o relacionamento entre os diferentes atores sociais. No caso, há uma disputa entre o poder hegemônico dos/as médicos/as e a tentativa da população de subverter algumas práticas sociais já consolidadas pelo discurso médico.

Fairclough (2003a) destaca o obscurecimento da linha divisória entre o real e o ficcional na narrativa jornalística, uma vez que a notícia não é a realidade, mas um discurso particular sobre parte dela. Nas palavras do autor:

Talvez devamos nos perguntar se a distinção entre narrativas noticiosas e narrativas ficcionais é realmente clara: a estética das histórias noticiosas parece se tornar uma questão cada vez mais saliente, às vezes às custas de sua capacidade de responder a eventos reais às custas de questões de verdade (FAIRCLOUGH, 2003a, p. 86)

Controlar o acesso à saúde é uma forma de os/as médicos/as regularem o mercado. Se há muita oferta, o preço diminui. Nessa linha, a ampliação da assistência e 
melhorias na qualidade dos serviços públicos contrariam os interesses corporativos. Por esse e outros motivos, o discurso médico age no sentido de representar o Programa Mais Médicos como desnecessário, dentre outras desqualificações.

Avaliar as práticas discursivas, representações e identidades do/a médico/a brasileiro/a significa aproximar-se dos diferentes aspectos da interação entre variados atores sociais e perceber de que forma cada um age na cobertura de seus próprios interesses. Somada a análises de cunho sociológico, por meio da análise textualmente orientada, podemos perceber de que modo uma entonação específica, um pronome, uma manchete jornalística, um tópico, um item lexical, uma metáfora, entre uma gama de outras propriedades semióticas do discurso, se relacionam a algo tão abstrato e geral como as relações de poder na sociedade.

As práticas sociais concretizadas pela linguagem, naturalizadas e legitimadas socialmente são de grande interesse para estudos críticos do discurso. Nesse sentido, o discurso médico atualmente realçado no contexto da contratação de médicos/as de outros países pelo governo brasileiro caracteriza-se como objeto de estudo relevante para a ADC, assim como emerge tendo destacável potencial de colaboração para estudos sociais de outras áreas do conhecimento.

Como citado anteriormente, Fairclough (2001) entende discurso como uma prática social reprodutora e transformadora de realidades sociais. Para ele, os indivíduos atuam na sociedade de acordo com formações ideológicas que incorporam ou combatem por meio da disseminação de discursos que representam suas crenças, conhecimentos ou experiências de vida. Assim:

O sujeito da linguagem, a partir de uma perspectiva psicossocial, está propenso ao amoldamento ideológico e linguístico, assim como é transformador de suas próprias práticas discursivas, contestando e reestruturando a dominação e as formações ideológicas socialmente empreendidas em seus discursos; ora ele se conforma às formações discursivas/sociais que o compõem, ora resiste a elas, ressignificando-as, reconfigurando-as. Desse modo, a linguagem é uma atividade dialética que molda a sociedade e é moldada por ela. (FAIRCLOUGH, 2001, p. 71)

Ademais, entendemos que o objeto de estudo de qualquer análise do discurso não se trata tão somente da língua, mas do que se realiza por meio dela: relações de poder, institucionalização de identidades sociais, processos ideológicos, enfim, diversas abordagens sobre diferentes aspectos da vida social. 
Chouliaraki \& Fairclough (1999, p. 60), em um enfoque da ADC como abordagem teórico-metodológica, oferecem um modelo de análise que, em síntese, abrange o problema (a vida social traduzida pelo discurso); os obstáculos à sua resolução (análises da conjuntura, da prática discursiva e do discurso); a função do problema na prática; os possíveis meios de sobrepujar os obstáculos; e a reflexão sobre a investigação empreendida, conforme retomaremos no Capítulo 3, sobre aspectos teóricometodológicos da pesquisa.

A ADC é um estudo de oposição às estruturas e às estratégias do discurso das elites. Ela se apresenta como um instrumental teórico para a análise das práticas discursivas que constroem as várias ordens sociais vigentes e como uma forma de investigação das formações discursivas que engendram as relações de poder, as representações e identidades sociais e os sistemas de conhecimento e crença, ou seja, "os analistas críticos do discurso pretendem mostrar o modo como as práticas linguísticodiscursivas estão imbricadas com as estruturas sociopolíticas mais abrangentes de poder e dominação" (KRESS, 1990, p.85)

Em outros termos, van Dijk (2008: 113) observa que o objetivo central das análises discursivas é identificar mecanismos pelos quais as assimetrias de poder são estabelecidas e sustentadas em textos orais e escritos e, acrescentamos, textos multimodais da web, buscando por meio de posicionamentos explícitos, contrariar para, amenizar ou eliminar determinadas desigualdades sociais. Nesse sentido, o autor defende que:

\begin{abstract}
A ADC é um tipo de investigação analítica discursiva que estuda principalmente o modo como o abuso de poder, a dominação e a desigualdade são representados, reproduzidos e combatidos por textos orais e escritos no contexto social e político. Com essa investigação de natureza tão dissidente, os analistas críticos do discurso adotam um posicionamento explícito e, assim, objetivam compreender, desvelar e, em última instância, opor-se à desigualdade social (VAN DIJK, 2008, p.113).
\end{abstract}

Também relevante, dentre todo seu pensamento sobre discurso, é a teoria que van Dijk formulou, a fim de entender o funcionamento da cognição social; a noção de acesso discursivo, que significa de que forma é dada a chance do indivíduo se inserir socialmente num discurso de domínio prestigiado. A partir do modo como determinado grupo tem acesso a dados discursos pressupõe-se como se constrói sua representação social. 
Através de um acesso especial ao discurso e à comunicação públicos bem como de um controle sobre eles, os grupos ou instituições dominantes podem influenciar as estruturas do texto e da fala, de modo que, como resultado, o conhecimento, as atitudes, as normas, os valores e as ideologias dos receptores sejam mais ou menos indiretamente afetados tendo em vista o interesse do grupo dominante. (VAN DIJK, 2012, pp.88 e 89).

Dada a centralidade dos meios de comunicação de massa nas sociedades modernas, os discursos por eles mediados merecem especial atenção, pois uma realidade comum está no fato de poucos conglomerados possuírem grande parte dos aparatos técnicos e institucionais de comunicação. Uma só empresa pode ser dona de diversos jornais, de canais de televisão, de rádio, de produtoras e distribuidoras de discos e de editoras. Nesta perspectiva é que a mídia é chamada de "quarto poder", uma percepção que sempre esteve presente, conforme Thompson (2011) demonstra em suas discussões sobre os meios de comunicação de massa.

Vivemos, hoje, em sociedades onde a produção e recepção das formas simbólicas é sempre mais mediada por uma rede complexa, transnacional, de interesses institucionais. A discussão desse processo implica várias considerações. Conceitualmente, devemos examinar a natureza das formas simbólicas e sua relação com os contextos sociais dentro dos quais elas são produzidas, transmitidas e recebidas, numa discussão que se situa dentro do território tradicionalmente marcado pelo conceito de cultura. Historicamente, devemos reconstruir o desenvolvimento de alguns dos meios técnicos de transmissão e das formas institucionais dentro das quais esses meios técnicos foram e, correntemente, ainda são tratados. Teoricamente, devemos refletir sobre a natureza desse processo geral de "midiação", sobre seu impacto na vida social e política do mundo moderno, sobre suas implicações para a teoria social e política em geral e para a teoria da ideologia em particular. (THOMPSON 2011, p.12)

Em suas anotações sobre os diversos entendimentos acerca da ideologia, Thompson (2011, p. 16) avalia que "o conceito de ideologia pode ser usado para se referir às maneiras como o sentido (significado) serve, em circunstâncias particulares, para estabelecer e sustentar relações de poder que são sistematicamente assimétricas”.

Dessa forma, podemos pensar o posicionamento dos/as médicos/as brasileiros/as diante do Programa Mais Médicos por uma perspectiva de operação da ideologia, que pretende manter suas práticas de acordo com interesses corporativos e colocar o/a médico/a como personagem principal na elaboração de políticas públicas de saúde, como veremos na análise do Texto 6. Antes disso, destacamos o refrão repetido pelos 
"doutores" e reverberado pela mídia: "não precisamos de mais médicos, precisamos, sim, de melhores condições de trabalho".

Talvez as melhores condições de trabalho nunca alcancem as expectativas desses/as médicos/as. Ou, pelo menos, pode ser que levemos um bom tempo para que tenhamos um governo capaz de construir hospitais similares às clínicas particulares de onde esses/as médicos/as não querem sair.

A partir do momento em que os meios de comunicação de massa se apropriam do discurso de que faltam condições de trabalho e o distribuem em larga escala pela sociedade, eles assumem a defesa da classe médica e ditam a forma "correta" de pensamento. Este empenho se configura na criação de um senso comum, que facilita a perpetuação de uma relação assimétrica de poder e consequente desigualdade social.

Abuso de poder. Esta é a denominação dada por Teun van Dijk para a dominação exercida pelas elites simbólicas, que têm acesso privilegiado aos discursos públicos e controlam a reprodução discursiva da dominação na sociedade. Logo, um dos grandes desafios dos tempos modernos consiste em estabelecer uma relação entre a comunicação e os planos de desenvolvimento geral das sociedades que possibilite a transmissão de ideias precisamente comprometidas com a satisfação de interesses coletivos. Como aponta Pieranti (2007):

Fortalecida, a comunicação passa a manter relação de interdependência com outras áreas alvo de políticas públicas, contribuindo também para seu desenvolvimento. Ainda que a comunicação, por si só, seja incapaz de gerar desenvolvimento, políticas públicas para outras áreas têm sua eficiência prejudicada, caso não haja condições para que ela se estabeleça. (PIERANTI, 2007, p. 23)

Portanto, políticas de comunicação não podem, assim, se restringirem à criação de infraestrutura e a investimentos a ela vinculados. Compete-lhes também criar as condições para a difusão democrática de ideias que contribuam para a diminuição das diferenças e injustiças sociais. Considerando a teoria sobre o acesso discursivo elaborada por van Dijk, significaria dizer que os discursos das elites simbólicas deveriam, então, permitir à coletividade maior participação em suas produções, reproduções e reformulações.

No material analisado nesta pesquisa perceberemos as diferenças no espaço dado à voz dos/as médicos/as brasileiros/as e dos/as médicos/as estrangeiros/as, particularmente os/as cubanos/as. Nos textos contra o programa, quem mais fala são os/as 
médicos/as brasileiros/as. O povo e os/as médicos/as cubanos/as, principais atores do Programa Mais Médicos, são apagados. Já nos textos a favor do programa, falam o povo, os/as médicos/as brasileiros/as, os/as cubanos/as e qualquer outro ator relacionado ao assunto.

A mídia tem papel relevante na intermediação desse conflito. Seja como portavoz da sociedade ou defensora de interesses particulares, suas expressões possuem alcance, legitimidade e efeitos diretos no amoldamento de discursos e práticas sociais, o que impacta na construção das identificações do/a profissional de saúde atualmente no Brasil.

Se considerarmos que grande parte do conhecimento que adquirimos é derivado dos jornais, da rádio e da televisão, é pertinente esperar que tais meios sejam democráticos em suas produções de conteúdo, afinal, as maneiras como participamos do sistema social são profundamente afetadas pela mídia.

De toda forma, perceberemos nas análises feitas neste trabalho que o espaço dado à voz dos/as médicos/as estrangeiros/as é reduzido ou nulo, mesmo que eles/as sejam as principais referências do texto jornalístico.

\section{2 - Significados do discurso}

Nesta seção abordarei o discurso como modo de interação, representação e identificação. Para isso, utilizarei formulações de Fairclough (2003), que sugere a noção de três principais tipos de significados do discurso: acional, representacional e identificacional.

O significado acional focaliza o texto como modo de inter(ação) em eventos sociais; o significado representacional enfatiza a representação de aspectos do mundo - físico, mental, social - em textos, e o significado identificacional, por sua vez, refere-se à construção e à negociação de identidades no discurso. (RESENDE \& RAMALHO 2006, p. 60)

Fairclough (2003) aponta para uma correspondência entre ação e gêneros, representação e discursos, identificação e estilos. Segundo o autor, gêneros, discursos e estilos são modos relativamente estáveis de agir, de representar e de identificar, respectivamente. 
A análise discursiva é um nível intermediário entre o texto em si e seu contexto social - eventos, práticas, estruturas. Então, a análise de discurso deve ser simultaneamente à análise de como os três tipos de significado são realizados em traços linguísticos dos textos e da conexão entre o evento social e práticas sociais, verificando-se quais gêneros, discursos e estilos são utilizados e como são articulados nos textos. Gêneros, discursos e estilos ligam o texto a outros elementos da esfera social - as relações internas do texto e suas relações externas. (RESENDE \& RAMALHO 2006, p. 61)

Esses significados correspondem às principais maneiras como a semiose figura em práticas sociais: como modos de agir, modos de representar e modos de ser, bem como aos elementos que compõem as ordens de discurso: gêneros, discursos, estilos. Gêneros constituem "o tipo de linguagem ligado a uma atividade social particular"; discursos implicam "o tipo de linguagem usado para construir algum aspecto da realidade de uma perspectiva particular" e estilos (ou vozes, segundo o termo original usado no livro), o "tipo de linguagem usado por uma categoria particular de pessoas e relacionado a sua identidade" (CHOULIARAKI \& FAIRCLOUGH, 1999: 63).

\subsection{1 - Significado identificacional e estilo}

Ao passo que as paisagens culturais da modernidade se modificam, elas moldam práticas sociais que interferem contundentemente no exercício da Medicina. Um exemplo é a influência de recursos tecnológicos superando o lado humanístico da prática médica. Cria-se uma dependência de equipamentos e a supervalorização dos medicamentos. A medicina preventiva perde lugar para a cura de doenças. O/a profissional passa a ser um/a intermediário/a entre o/a paciente e uma máquina de diagnóstico, ou apenas um/a apontador/a dos melhores princípios ativos. Isso implica a venda de tratamentos ao invés da prevenção de enfermidades.

Nesse cenário, a identidade do/a médico/a brasileiro/a vem sendo massivamente discutida a partir da polêmica gerada pelo Programa Mais Médicos. Além disso, o debate no Brasil sobre a convocação de médicos/as estrangeiros/as - cubanos/as e de outros países - acabou prejudicado pela falta de informações vitais do governo, pela cobertura míope da mídia e pela reação apavorada dos/as médicos/as brasileiros/as. Todos esses, fatores que seguramente interessam ao processo de identificação desses/as profissionais.

Nesse sentido, tratarei aqui do significado identificacional do discurso, relacionado ao conceito de "estilo". Segundo Resende e Ramalho (2006) estilos 
constituem o aspecto discursivo de identidades, ou seja, relacionam-se à identificação de atores sociais em textos. Mas como observa Fairclough (2003, p.161) a identificação é um processo complexo que necessita da distinção entre os aspectos pessoais e sociais da identidade. "A Identidade não pode ser reduzida à identidade social, o que em parte significa que identificação não é um processo puramente textual, não apenas uma questão de linguagem". Portanto, este estudo sobre identificações deve levar em consideração as formulações da sociedade e dos/as médicos/as na constituição da identidade destes/as profissionais. Ou seja, há que se considerar não só o que as pessoas pensam dos/as médicos/as, mas o que os/as próprios/as médicos/as pensam de si.

De acordo com Hall (1992), a questão da identidade está sendo extensamente discutida na teoria social. Em essência, o argumento é o seguinte: as velhas identidades, que por tanto tempo estabilizaram o mundo social, estão em declínio, fazendo surgir novas identidades e fragmentando o indivíduo moderno, até aqui visto como um sujeito unificado. Assim, a chamada "crise de identidade" é vista como parte de um processo mais amplo de mudança, que está deslocando as estruturas e processos centrais das sociedades modernas e abalando os quadros de referência que davam aos indivíduos uma ancoragem mais estável no mundo social.

Hall (1992) atravessa três etapas na descrição do conceito de identidade. Em primeiro lugar, ele faz referência ao sujeito do Iluminismo, caracterizado como indivíduo centrado, unificado, dotado das capacidades de razão, consciência e ação. Em segundo, ele descreve o sujeito sociológico, no qual a identidade é formada na interação entre o "eu" e a sociedade. Por fim, ele fala do sujeito pós-moderno, conceitualizado como não tendo uma identidade fixa, essencial ou permanente. Isso significa dizer que não há mais um indivíduo totalmente centrado, unificado. "Dentro de nós há identidades contraditórias, empurrando em diferentes direções, de tal modo que nossas identificações estão sendo continuamente deslocadas" (Hall, 1992, p.13).

Como observa o crítico cultural Mercer (1990, p. 43 apud Hall, 1992, p. 13), "a identidade somente se torna uma questão quando está em crise, quando algo que se supõe como fixo, coerente e estável é deslocado pela experiência da dúvida e da incerteza". Trazendo para o foco da pesquisa, poderíamos dizer que os/as médicos/as estão passando por uma crise de identidade? Investigar esses aspectos é um dos objetivos aqui propostos.

A identidade tem uma relação estreita de dependência com a diferença. O que se percebe nos textos analisados é uma constante batalha identitária. No viés do povo, o perfil do/a médico/a cubano/a é construído ressaltando as características positivas da 
Medicina daquele país. Na ótica dos/as médicos/as brasileiros/as, a Medicina cubana é de baixa qualidade, portanto, seus/suas médicos/as também. Cada grupo resguarda seus principais interesses na construção dessas identidades.

Conforme observa Fairclough (2003), a criação ou proliferação de diferenças e a subversão ou ofuscação de diferenças entre objetos, entidades, eventos e atores sociais em representações são aspectos do processo social contínuo de classificação. Assim, verificar como se dá o embate discursivo entre identidades é uma questão não só deste trabalho, mas da ADC de uma forma geral.

Considerando que identidades são construções sociais que solidificam modos de ser e agir, as análises aqui desenvolvidas pretendem tornar claras as intenções de determinadas produções simbólicas que criam e sustentam desigualdades sociais. Castells (1999, p.23) aponta que:

toda e qualquer identidade é construída e para ele a principal questão acerca da construção da identidade é "como, a partir de que, por quem e para quê isso acontece", uma vez que isso é determinante do conteúdo simbólico da identidade. (apud RESENDE \& RAMALHO 2006)

Seguindo as diretrizes de Castells (1999), poderia responder seus questionamentos com a análise mais profunda que será desenvolvida no Capítulo 4. Entretanto, antecipo alguns comentários relevantes para um melhor entendimento posterior.

Nos dois veículos utilizados como material discursivo de pesquisa para este estudo, as formas de publicação de conteúdo são as mesmas: mídias digitais com propósitos e objetivos muito bem delineados. Tanto o Conselho Federal de Medicina quanto o Pragmatismo Político disponibilizam informações segundo uma linha editorial estabelecida em suas missões institucionais.

A diferença entre os dois está nos processos ideológicos que configuram os modos de representação dos atores para a constituição de identidades particulares. Como verificado na pesquisa, enquanto o CFM tende a desqualificar e desvalorizar médicos/as estrangeiros/as, o Pragmatismo Político tende a trabalhar em prol da valorização e aceitação do Programa Mais Médicos no Brasil. Naturalmente, pode-se imaginar que as construções de identidades se distanciam na medida em que os interesses também são distantes, como pretendemos deixar mais nítido na seção seguinte. 


\subsection{2 - Significado representacional e discurso}

A teoria de representação dos atores sociais, de van Leeuwen (1997), nos fornece um instrumental que possibilita a observação do papel social desempenhado pelos envolvidos em um discurso. Ou seja, através da realização das representações, podemos perceber a utilização de estratégias que atendem a determinados objetivos do enunciador em relação à sua pretensa audiência.

Nesta seção aspiro mostrar essas diferentes possibilidades de representação dos atores sociais por meio das opções que a língua oferece para nos referirmos às pessoas. Se são elas representadas impessoal ou pessoalmente, individual ou coletivamente, através de referência à sua pessoa ou ao seu enunciado, etc.

O significado representacional de textos diz respeito a como alguns aspectos do mundo são representados nos discursos. Segundo Fairclough (2003) diferentes discursos são formas diferentes de ver o mundo de acordo com as diferentes relações que cada um estabelece com o mundo e com as outras pessoas.

As relações estabelecidas entre diferentes discursos podem ser de diversos tipos, a exemplo das relações estabelecidas entre pessoas discursos podem complementar-se ou podem competir um com o outro, em relações de dominação -, porque os discursos constituem parte do recurso utilizado por atores sociais para se relacionarem, cooperando, competindo, dominando. (RESENDE \& RAMALHO 2006, p. 71)

Importante lembrar que assim como a língua verbal pode representar ações sociais, os mesmos efeitos podem ser produzidos por outras semioses. Como menciona van Leeuwen (1998, p.171) “o significado é inerente à cultura e não à língua e não pode ser associado a uma semiótica específica”. Pontuo essa observação porque van Leeuwen pretende que as categorias a seguir, por ele propostas, sejam vistas como pan-semióticas.

Este ponto é importante para a análise crítica do discurso, visto que, com a crescente utilização da representação visual numa enorme variedade de contextos, torna-se cada vez mais urgente ser capaz de formular as mesmas questões críticas em relação às representações quer verbais quer visuais, ou seja, na realidade, em relação às representações em todos os media que constituem parte dos textos multimídia contemporâneos. (VAN LEEUWEN, 1998 p, 171) 
Como o corpus principal é formado por textos de veículos on line, cuja característica principal é a multimodalidade dos meios, também farei análises de fotos que ilustram as matérias, pois como prega o bom fotojornalismo, a imagem deve acrescentar informações ao texto e não apenas ilustrar aquilo que o texto já disse. Nessa linha, Halliday (1989), nos esclarece que:

[...] existem muitos outros modos de significado, em qualquer cultura, os quais estão fora do campo da linguagem. [...] Isto inclui tanto formas de arte como a pintura, a escultura, a música, a dança, e assim por diante, e outros modos de comportamento cultural que não estejam classificados como formas de arte, tais como formas de troca, modos de se vestir, estruturas da família, etc. Estas são algumas das formas de significado na cultura. De fato, nós podemos definir uma cultura como um conjunto de sistemas semióticos, um conjunto de sistemas de significado, estando assim, todos eles inter-relacinados (HALLIDAY, 1989, p. 4).

Mais adiante, no Capítulo 4, discutirei os modos como certas escolhas lexicais e construções linguístico-discursivas permitem ao enunciador imprimir significados que sirvam a interesses específicos. Para tanto, as noções de agente e paciente são especialmente relevantes nesse estudo por dois motivos.

Primeiro, por significar na vida prática os dois polos da relação cotidiana nos hospitais: de um lado temos o Doutor (agente) e do outro o enfermo (paciente). Tal situação carrega em si a noção de hierarquia na relação médico/a-paciente, o que implica na representação do/a médico/a como um ser superior.

Segundo, porque agente e paciente nas acepções linguística e sociológica podem ter ou não congruência em seus papéis. O/a médico/a pode ser representado/a em textos como agente ou paciente de uma determinada ação. Assim explica van Leeuwen (1998, p. 169):

A agência, por exemplo, enquanto conceito sociológico, revela-se da maior importância clássica na análise crítica do discurso: quais os atores sociais e em que contextos estão eles representados como agentes e como pacientes? Mas a agência sociológica nem sempre é realizada pela agência linguística, pelo papel gramatical do agente, (...).

Como não há essa co-referência exata entre as categorias sociológicas e linguísticas, é necessário que a análise seja feita levando em consideração as duas 
abordagens sobre agência para que não se perca exemplos relevantes, pois um mesmo texto pode envolver diferentes discursos.

Em um mesmo texto é comum haver um discurso protagonista e outro antagonista. Nesse caso, os dois são articulados de forma que um faça a negação do outro. Ou seja, nos discursos aqui analisados, podemos perceber visões antagônicas sobre um mesmo aspecto do mundo: o Programa Mais Médicos.

Para adequação aos objetivos do trabalho serão exploradas apenas algumas categorias de representação de atores sociais. As mais evidentes nos textos analisados são a exclusão, a assimilação, a associação, a nomeação, a categorização e a diferenciação.

A exclusão, como o próprio nome diz, é a não inclusão de um ator ou grupo de atores em uma representação social. Ela pode ser feita de forma inocente ou como estratégia de fortalecimento de um discurso específico. Para van Leeuwen (1998, p. 180):

\begin{abstract}
Algumas exclusões não deixam marcas na representação, excluindo quer os atores quer as suas atividades. Uma exclusão tão radical pode desempenhar o seu papel numa comparação crítica de diferentes representações de uma mesma prática social, mas não na análise de um único texto, pela simples razão de que não deixa marcas.
\end{abstract}

Os textos analisados neste trabalho tornam nítidos os sentidos em potencial que o CFM desenvolve em seu discurso com a supressão dos cidadãos que sofrem a carência de atendimento médico. Desta forma, o Conselho atribui à classe médica a exclusividade de julgar se é legítimo ou não o Programa Mais Médicos.

A assimilação acontece quando os atores sociais são referidos como grupos. Leeuwen (1998, p. 195) distingue dois tipos principais de assimilação: a agregação e a coletivização. "O primeiro quantifica grupos de participantes, tratando-os como dados estatísticos, o mesmo não acontece com o segundo". Ainda segundo o autor, "a agregação é muitas vezes usada para regulamentar a prática e para produzir uma opinião de consenso, mesmo que se apresente como mero registro de fatos".

Outro modo de representar atores sociais como grupos é a associação. Ela consiste na formação de grupos que nunca são classificados no texto, embora os atores ou grupos que integram a associação possam, naturalmente, ser nomeados e/ou categorizados.

A nomeação se dá quando os atores são representados em termos de sua identidade única, recebendo, assim, um papel de maior importância no texto. Realiza-se tipicamente 
através de nomes próprios. Porém, podem ocorrer sob a forma de honorificação, adição de títulos padrão, cargos etc.

$\mathrm{Na}$ categorização, por sua vez, os atores são representados em termos de identidades ou funções que partilham com outros. Esta categoria também possui duas subdivisões, a funcionalização e a identificação. Para Leeuwen (1998), a primeira "ocorre quando os atores sociais são referidos em termos de uma atividade, em termos de alguma coisa que fazem, por exemplo uma ocupação ou função". Na identificação os atores sociais são definidos, não em termos daquilo que fazem, mas em termos daquilo que, mais ou menos permanente, ou inevitavelmente, são.

No caso da diferenciação, o ator social ou grupo de atores é diferenciado de um ator ou grupo semelhante, criando a diferença entre o próprio e o outro, ou entre nós e eles. Como veremos nas análises, a diferenciação favorece o modo de operação da ideologia denominado fragmentação. Mais especificamente, a diferenciação cria condições para o expurgo do outro. Observe o quadro-resumo abaixo.

Quadro 3 - Categorias de representação de atores sociais

\begin{tabular}{|c|c|}
\hline EXCLUSÃO & Ator ou grupo de atores excluídos do texto \\
\hline ASSIMILAÇÃO & $\begin{array}{l}\text { Agregação - quantifica grupos em dados } \\
\text { estatísticos } \\
\text { Coletivização - não quantifica }\end{array}$ \\
\hline ASSOCIAÇÃO & $\begin{array}{l}\text { Não nomeia grupos que poderiam ser } \\
\text { nomeados no texto }\end{array}$ \\
\hline NOMEAÇÃO & $\begin{array}{l}\text { Atores representados em termos de suas } \\
\text { identidades }\end{array}$ \\
\hline CATEGORIZAÇÃO & $\begin{array}{l}\text { Fucionalização }- \text { atores representados } \\
\text { pelo que fazem } \\
\text { Identificação - atores representados pelo } \\
\text { que são }\end{array}$ \\
\hline DIFERENCIAÇÃO & $\begin{array}{l}\text { Diferencia atores ou grupos de atores } \\
\text { iguais }\end{array}$ \\
\hline
\end{tabular}

Com base em van Leeuwen (1997)

\subsection{3 - Significado (inter)acional e gênero discursivo}

Quando falamos de gênero discursivo, estamos nos referindo a modos específicos e recorrentes de interação. Para Fairclough (2003, p. 65), "gêneros são o aspecto especificamente discursivo de formas de agir e interagir no curso dos eventos sociais". Cada gênero possui suas peculiaridades que satisfazem determinados objetivos de 
comunicação. Portanto, esta parte se encarrega de apresentar de que maneira os atores sociais estudados agem e interagem no mundo por meio de algumas convenções discursivas. Segundo (Resende e Ramalho, 2006, p. 62) "cada prática social produz e utiliza gêneros discursivos particulares, que articulam estilos e discursos de maneira relativamente estável num determinado contexto sócio-histórico e cultural".

Algumas considerações sobre gêneros são colocadas por Fairclough (2003): eles variam consideravelmente em termos de seu grau de estabilização, fixidez e homogeneização - alguns são tão bem definidos a ponto de serem ritualizados, enquanto outros estão em constante fluxo; e não há terminologia especificamente estabelecida para os gêneros. O autor sugere que a análise dos gêneros deve conter: (1) análise das cadeias genéricas, (2) análise das misturas de gêneros em um texto e, (3) análise de gêneros individuais em um texto particular. Se focalizarmos neste último ponto, estamos nos propondo a observar o caráter interdiscursivo de um texto (a mistura de gêneros, discursos e estilos) realizado em seus traços semânticos, gramaticais e lexicais.

Segundo Fairclough, os gêneros podem ser definidos de acordo com diferentes níveis de abstração. Os pré-gêneros são os gêneros em um alto nível de abstração, como a narrativa, o diálogo, a argumentação e a descrição. Eles são categorias que transcendem redes particulares de práticas sociais. Ainda de acordo com Fairclough (2003), há também os gêneros desencaixados, aqueles que são menos abstratos que a narrativa, por exemplo, mas que transcendem ainda redes particulares de práticas sociais, como é o caso da entrevista. E, além desses, há os gêneros situados: aqueles que são específicos para redes de práticas particulares, como a entrevista etnográfica.

Porém, os textos podem ser inovadores em termos de gênero, misturando vários tipos deste. Os formatos, textos que são construídos a partir de diferentes textos pertencentes a diferentes gêneros, como é o caso dos websites, são um bom exemplo dessa mistura. Contudo, em certos casos, podemos perceber uma herarquia genérica nos textos, havendo um gênero principal e alguns sub-gêneros.

Os gêneros individuais de um texto ou interação podem ser analisados, segundo Fairclough (2003), em termo de (1) atividade (o que as pessoas estão fazendo discursivamente), (2) relações sociais (quais são as relações sociais entre elas) e (3) tecnologia comunicativa (de qual tecnologia de comunicação a atividade depende).

Isso nos remete à seleção/rejeição, confecção e distribuição de notícias pelos meios de comunicação aqui analisados. Esses processos variam de acordo com os objetivos perseguidos por cada veículo. No caso do CFM, por exemplo, critérios 
organizacionais e coorporativos parecem ser os de maior preponderância na seleção de conteúdo. Aliás, este site pode ser visto como um distribuidor do que eu arriscaria chamar de clipping positivo da classe médica.

Para abordar a seleção das notícias, falarei então sobre o conceito do gatekeeper. Em termos atuais seria o editor-chefe de um jornal. É um selecionador de conteúdo que se guia por critérios profissionais, políticos, organizacionais, burocráticos, econômicos etc. Conforme Donohue-Tichenor-Olien nos explica:

O gatekeeping nos meios de comunicação de massa inclui todas as formas de controle da informação, que podem ser determinadas nas decisões sobre a codificação das mensagens, a seleção, a formação da mensagem, a difusão, a programação, a exclusão de toda a mensagem ou dos seus componentes. (DONOHUE-TICHENOR-OLIEN, 1972, p. 42 apud WOLF, 2003, p. 186)

Essas atribuições do gatekeeper dizem respeito às formas de construção simbólica dos discursos e serão adiante exploradas com base em diferentes categorias de análise textual. Perceberemos de que maneira as diferentes inclinações políticas, econômicas, sociais, todas potencialmente ideológicas, se manifestam na construção de textos particulares pelo Pragmatismo Político e pelo Conselho Federal de Medicina.

O primeiro, veículo "alternativo" que se propõe a discutir temas gerais relacionados à vida em sociedade, exerce um papel semelhante ao dos grandes jornais de tradição no país. Funciona de acordo com a mesma lógica de produção e seleção de conteúdo e utiliza a mesma tecnologia que é utilizada pelas grandes empresas da mídia brasiliera: a internet. As publicações do Pragmatismo Político são, em sua maioria, do gênero 'texto jornalístico'.

O segundo, representante da classe médica brasileira, tem a função própria de um assessor de imprensa, qual seja, manter a boa imagem de seu cliente e contornar situações de crise. Portanto, trabalha temas setoriais seguindo sempre a mesma tendência, publicar somente o que for positivo à instituição "médicos". Logo, o Portal Médico não possui um gênero definido para seus textos, mesmo que, assim como o Pragmatismo Político, trabalhe com textos para a internet.

No entanto, os dois veículos exploram a principal característica dos meios modernos de comunicação, a visibilidade mediada. Segundo Thompson (2008, p. 2), "trata-se de de uma estratégia explícita por parte daqueles que bem sabem ser a 
visibilidade mediada uma arma possível no enfrentamento das lutas diárias". Assim, Thompson fala de uma 'nova visibilidade' proporcionada pela internet, suporte que proporciona maior eficiência na comunicação a partir do momento em que a distância se torna irrelevante e a instantaneidade se faz presente.

Tal característica da internet facilita a produção e disseminação de conteúdos potencialmente ideológicos que obtêm resultados mais eficientes em detrimento das formas tradicionais de distribuição de formas simbólicas. Na próxima seção abordaremos de maneira mais profunda os mecanismos de produção e reprodução de conteúdos ideológicos.

\section{3 - Teoria Crítica da Ideologia}

A abordagem da ideologia que aqui será feita diz respeito às maneiras como as formas simbólicas se entrecruzam com relações de poder. Trata-se da maneira como os sentidos são mobilizados para reforçar pessoas e grupos que ocupam posições de poder. Tais sentidos são vistos como potencialmente ideológicos. Para a perspectiva crítica de Thompson (2001, p. 76) "estudar a ideologia é estudar as maneiras como o sentido serve para estabelecer e sustentar relações de dominação".

Portanto, o estudo da ideologia viabiliza analisar as diversas possibilidades de construção de sentidos, segundo as várias semioses disponíveis nos sistemas de comunicação. Neste ponto temos um elo entre a Teoria da Ideologia de Thompson (2011) e a ADC, conforme apresentado por Fairclough (2003). Pode - se considerar que o estudo da ideologia se desenvolve amparado pela Análise de Discurso Crítica e vice-versa, a partir do momento que se avalia imprescindível, por exemplo, a investigação de contextos sociais dentro dos quais as formas simbólicas são empregadas e articuladas. Thompson (2011: 16) reforça essa observação ao considerar que "a distintividade do estudo da ideologia está na seguinte questão: ele exige que perguntemos se o sentido, construído e usado pelas formas simbólicas, serve ou não para manter relações de poder sistematicamente assimétricas". E vai além:

A análise da ideologia pode ser vista como uma parte integrante de um interesse mais geral ligado às características da ação e da interação, às formas de poder e de dominação, à natureza da estrutura social, à reprodução e à mudança social, às qualidades das formas simbólicas e seus papéis na vida social. (THOMPSON, 2011, p. 16) 
Por formas simbólicas, Thompson (2011) entende que é um amplo espectro de ações e falas, imagens e textos, que são produzidos por sujeitos e reconhecidos por eles e outros como construtos significativos, ou seja, o discurso tal qual entendido por Fairclough (2001, 2003, CF 1999). Tais construções podem organizar-se nos principais 'modos gerais de operação da ideologia'. Thompson (2011) distingue cinco modos em especial: "legitimação", “dissimulação", “unificação", “fragmentação" e "reificação", conforme o quadro seguinte.

Quadro 4 - Modos de operação da ideologia.

\begin{tabular}{|l|l|}
\hline \multicolumn{1}{|c|}{ Modos Gerais } & \multicolumn{1}{c|}{$\begin{array}{c}\text { Algumas estratégias típicas de } \\
\text { construções simbólicas }\end{array}$} \\
\hline LEGITIMAÇÃO & $\begin{array}{l}\text { Racionalização } \\
\text { Universalização } \\
\text { Narrativização }\end{array}$ \\
\hline DISSIMULAÇÃO & $\begin{array}{l}\text { Deslocamento } \\
\text { Eufemização } \\
\text { Tropo (sinédoque, metonímia, metáfora) }\end{array}$ \\
\hline UNIFICAÇÃO & Estandardização \\
Simbolização da unidade
\end{tabular}

Adaptado de Thompson (2011)

Na sequência, abordarei mais detalhadamente esses modos gerais de operação da ideologia, destacando aqueles mais evidentes nos textos analisados. Assim sendo, introduzirei a temática explorando o conceito de fragmentação.

Segundo Thompson (2011), a fragmentação acontece quando não há a unificação de pessoas numa coletividade, mas sim a segmentação dos indivíduos e grupos que possam ser capazes de se transformar em um desafio real aos grupos dominantes. 
Acontece também quando forças de oposição potencial são dirigidas a um alvo que é projetado como hostil.

A fragmentação pode ocorrer através de duas estratégias de construção simbólica: a diferenciação e o expurgo do outro. A diferenciação consiste no enfoque das diferenças e divisões entre as pessoas ou grupos a fim de causar a desagregação e impedir que constituam um desafio efetivo às relações existentes. $\mathrm{O}$ expurgo do outro, segundo Thompson (2011), "envolve a construção de um inimigo, seja ele interno ou externo, que é retratado como mau, perigoso e ameaçador, e contra o qual os indivíduos são chamados a resistir coletivamente ou a expurga-lo".

A legitimação estabelece e sustenta relações de dominação, como observou Max Weber, pelo fato de serem representadas como legítimas, isto é, como justas e dignas de apoio. Weber distinguiu três tipos de fundamentos sobre os quais afirmações de legitimação podem estar baseadas: fundamentos racionais (que fazem apelo à legalidade de regras dadas), fundamentos tradicionais (que fazem apelo à sacralidade de tradições imemoriais) e fundamentos carismáticos (que fazem apelo ao caráter excepcional de uma pessoa individual que exerça autoridade). As estratégias de construção simbólica típicas da legitimação são a racionalização, a universalização e a narrativização.

Outro modo de operação da ideologia é a dissimulação. Com ela, relações de dominação podem ser estabelecidas e sustentadas pelo fato de serem ocultadas, negadas ou obscurecidas, ou pelo fato de serem representadas de uma maneira que desvia nossa atenção, ou passa por cima de relações e processos existentes.

Uma das estratégias de construção simbólica para a dissimulação seria o deslocamento. Neste caso, um termo costumeiramente usado para se referir a um determinado objeto ou pessoa é usado para se referir a outro e, com isso, as conotações positivas ou negativas do termo são transferidas para o outro objeto ou pessoa.

Outra estratégia é a eufemização. Aqui, ações, instituições ou relações sociais são descritas ou redescritas de modo a despertar uma valoração positiva. No linguajar popular, é o mesmo que falar mal com palavras doces; dar tapas com mão de pelica.

Temos ainda a estratégia chamada tropo. É o modo figurativo da linguagem ou, mais em geral, das formas simbólicas. O Uso do tropo é, geralmente, confinado ao domínio da literatura, mas o uso figurativo da linguagem é muito mais amplo do que essa especialização disciplinar possa sugerir. Entre as formas mais comuns de tropo estão a sinédoque, a metonímia e a metáfora. 
O uso figurativo da linguagem é uma característica bastante comum do discurso cotidiano, que é uma maneira eficaz de mobilizar o sentido no mundo sócio histórico, e que, em certos contextos, o sentido mobilizado desse modo pode estar envolto em poder, podendo servir para criar, sustentar e reproduzir relações de dominação.

Voltando aos modos gerais de operação da ideologia, temos a unificação. Com ela, as relações de dominação podem ser estabelecidas e sustentadas através da construção, no nível simbólico, de uma forma de unidade que interliga os indivíduos numa identidade coletiva, independentemente das diferenças e divisões que possam separá-los. A padronização é uma das estratégias de construção simbólica, por meio da qual formas simbólicas são adaptadas a um referencial padrão, que é proposto como um fundamento partilhado e aceitável de troca simbólica. Além dela temos a simbolização da unidade, que envolve a construção de símbolos de unidade, de identidade e de identificação coletivas, que são difundidos através de um grupo, ou de uma pluralidade de grupos.

O último modo de operação da ideologia que falaremos é a reificação. Com sua utilização, relações de dominação podem ser estabelecidas e sustentadas pela retratação de uma situação transitória, histórica, como se fosse permanente, natural, atemporal.

A naturalização é uma estratégia típica de construção simbólica da reificação. Acontece quando um estado de coisas que é uma criação social e histórica é tratado como um acontecimento natural ou como um resultado inevitável de características naturais. Por exemplo, a divisão socialmente instituída do trabalho entre homens e mulheres, que pode ser retratada como um resultado de características fisiológicas nos sexos, ou de diferenças entre sexos.

Outra estratégia é a eternalização. Com ela, fenômenos sócio-históricos são esvaziados de seu caráter histórico ao serem apresentados como permanentes, imutáveis e recorrentes.

Há também a nominalização, que ocorre quando sentenças, ou parte delas, ou descrições da ação e dos participantes nelas envolvidos, são transformadas em nomes. Assim, quando falamos em, por exemplo, "o banimento das importações", ao invés de "o Primeiro-Ministro decidiu banir as importações", essa nominalização dá ao acontecimento um caráter impessoal, como se fosse um fenômeno espontâneo, desviando a atenção do leitor da ação cometida por um agente específico.

Por último, temos a passivização, estratégia que coloca verbos na voz passiva, como quando dizemos que "o suspeito está sendo investigado", ao invés de "os policiais 
estão investigando o suspeito". A nominalização e a passivização concentram a atenção do ouvinte ou leitor em certos temas com prejuízo de outros.

\section{4 - Teorias de Comunicação}

Para enriquecer este estudo realizado acerca do Programa Mais Médicos, acreditamos que algumas teorias das comunicações de massa possam contribuir de forma esclarecedora para a compreensão das implicações que a mídia tem nas estruturas sociais. A Teoria Funcionalista da Mídia talvez esteja no centro dessa discussão, por se preocupar com as funções desenvolvidas pelo sistema das comunicações de massa. Esta teoria inova na maneira de fazer pesquisas em comunicação, como avalia Wolf:

Este é o ponto mais distante das teorias precedentes: a interrogação fundamental não é mais sobre os efeitos, mas sobre as funções desenvolvidas pelas comunicações de massa na sociedade. Desse modo, completa-se o percurso seguido pela pesquisa de mídia, que no início havia se concentrado nos problemas da manipulação, para passar aos da persuasão e depois à influência, atingindo justamente as funções. (WOLF, 2003, p. 50)

Por exemplo, se pensarmos na conservação de valores na sociedade, o aparato das comuncações de massa pode ser visto no aspecto funcional, na medida em que cumpre a tarefa de corroborar e preservar alguns modelos de comportamento existentes no sistema social. Assim, os grandes veículos de comunicação acabam por favorecer a manutenção de um poder hegemônico que estabelece e sustenta injustiças sociais.

Visto que são sustentados pelas grandes empresas inseridas no atual sistema social e econômico, os meios de comunicação de massa contribuem para manter esse sistema [...]; o impulso que leva ao conformismo e é exercitado pelos meios de comunicação de massa deriva não apenas do que é dito, mas sobretudo do que é ocultado. De fato, esses meios não apenas continuam a afirmar o status quo, mas, na mesma medida, deixam de levantar os problemas essenciais acerca da estrutura social [...] Os meios de comunicação comercializados ignoram os objetivos sociais quando estes se chocam com a vontade econômica [...] Ao ignorar sistematicamente os aspectos controversos da sociedade, a pressão econômica impulsiona em direção ao conformismo. (LAZARSFELD-MERTON, 1948, p.86 apud WOLF, 2003, p.58) 
Percebemos que o Mais Médicos foi representado por meio desses desvios de conduta inerentes aos grandes veículos de comunicação, o que endossou o discurso da classe médica contrária ao programa. A falta de informações completas, a distorção de fatos, a seleção unilateral de vozes representadas e a pouca preocupação com o fato social em si contribuíram para a manutenção de um discurso que privilegia os/as médicos/as enquanto desconsidera a saúde e a vida de milhares de brasileiros/as.

O Jornalismo e o comportamento dos veículos de comunicação refletem realidades sujeitas a inúmeras variáveis. É um terreno movediço, que muitas vezes escapa da compreensão. Para entendê-lo, não há fórmulas ou receitas prontas, mas sim capacidade permanente de rever teorias e reconstruir práticas.

Abrir um canal direto com o público através da imprensa é tarefa de muitos e importantes agentes, a começar pelo repórter. Para que seja estabelecida uma relação justa e leal entre produtores e consumidores de informação, deve-se privilegiar a matéria-prima do jornalismo: ouvir boas fontes, com credibilidade, informação qualificada, clareza, domínio dos assuntos e, sobretudo, sensibilidade para as expectativas do cidadão destinatário final da comunicação.

No entanto, a representação discursiva do Programa Mais Médicos por alguns veículos de comunicação não se preocupou em satisfazer essas demandas sociais do jornalismo. O vestígio mais comum da falta de comprometimento com a apuração ética da informação se revela na exclusão de vozes relevantes para a efetivação da relação justa e leal entre produtores da infomação e público destinatário.

O jornalismo e a legitimidade da imprensa sempre foram lastreados na entidade intitulada “opinião pública". Essa atitude não muda, mesmo que hoje a esfera pública esteja cada vez mais dispersa, segmentada, fragmentada e mesmo que a diversificação das mídias tenha o efeito de despedir do cenário as grandes audiências de massa. Mas o que muda é a índole da informação, do debate, da crítica quando o caráter da comunicação de massa é alterado pela comercialização. Segundo Jürgen Habermas:

Quando as leis do mercado que governam a esfera da troca de mercadorias e do trabalho social invadem também a esfera reservada às pessoas particulares como um público, o debate racional-crítico tende a ser substituído pelo consumo, e a teia de comunicação pública se transforma em ações de recepção individualizada, embora de modo uniforme. (HABERMAS, 1991, p.161 apud THOMPSON, 2011, p. 148) 
Mudam também os limites da esfera pública. A internet trouxe uma reformulação ainda inacabada sobre o conceito. Porém, o que já sabemos é que houve uma ampliação da esfera pública a ponto de não termos ainda as medidas precisas dessa expansão. No entanto, o Portal Médico age no sentido contrário. Reduz a arena de dabate acerca dos temas de seu interesse ao limtie se seu público alvo, deixando expresso nitidamente sua intenção de conversar apenas com médicos/as ou grupos de interesse do setor. Logo, seu discurso alcança o máximo de eficácia na conformação de um bloco fechado e centrado apenas em seus próprios benefícios. Como esclarece a abordagem empírico-experimental ou da persuasão,

A persuasão dos destinatários é um objetivo possível, sob a condição de que a forma e a organização da mensagem sejam adequadas aos fatores pessoais que o destinatário ativa na interpretação da própria mensagem: em outras palavras, "as mensagens da mídia contêm características particulares do estímulo, que interagem de maneira diferente com os traços específicos da personalidade dos membros que compõem o público. A partir do momento em que existem diferenças individuais nas características da personalidade entre os membros do público, é natural pressupor que nos efeitos haverá variações correspondentes a essas diferenças individuais" (DE FLEUR, 1970, p.122 apud WOLF, 2003, p.18)

Considerando que o Portal Médico se pronuncia para um público de médicos/as, as diferenças individuais de seus/suas destinatários/as são reduzidas, alcançando assim a maior eficácia em seu propósito de persuasão. Portanto, o veículo não representa uma arena pública na acepção mais ampla do conceito.

Embora conceito impreciso, vago, "opinião pública" tem sido a bandeira que sustenta as ações da mídia. Sob esse prisma, é importante que os veículos tornem público aquilo que realmente seja de interesse público. Logo, a crítica do acontecimento deve acompanhar o fato em questão para que a opinião pública seja estruturada. Pois, como claramente se refere Maurice Mouillaud (1997: 50), "os acontecimentos explodem na superfície da mídia sobre a qual se inscrevem como sobre uma membrana sensível. Mas põem em ressonância os sentidos que nela são inscritos".

Por isso devemos refletir sobre os efeitos da mídia e como estes constroem a imagem da realidade social. Seguindo uma alteração de paradigma no estudo das comunicações, os efeitos entendidos como mudanças de curto prazo passaram a ser vistos como consequências de longo período. Para Roberts (1972): 
Conquistou-se a consciência de que "as comunicações não intervêm diretamente no comportamento explícito; de preferência, tendem a influenciar o modo como o destinatário organiza a própria imagem do ambiente. (ROBERTS, 1972, p.361 apud WOLF, 2003, p. 138)

Temos então que a influência do comunicador é baseada muitas vezes na sua capacidade de modificar a imagem do que é ou não importante, dos temas e problemas que estão sendo discutidos. Esse papel tem contribuição de grande relevância para a construção de realidades simbólicas e a formação da opinião pública. Como avalia LangLang:

Desse modo, os meios de comunicação de massa exercem a influência que têm, uma vez que constituem algo mais do que um simples canal (...). Ao filtrar, estruturar e enfatizar determinadas atividades públicas, o conteúdo da mídia não se limita a transmitir o que os porta-vozes proclamam (...) os meios de comunicação de massa fornecem perspectivas, modelam as imagens, ajudam a promover temas (...). (LANG-LANG, 1962, p.689 apud WOLF, 2003, p.141)

Pensando no papel da mídia de pautar a sociedade e por ela ser pautada, dando relevo a temas específicos de acordo com demandas sociais, econômicas, políticas, entre outras, podemos explorar a hipótese da agenda-setting. Ela sustenta que:

Em consequência da ação dos jornais, da televisão e dos outros meios de informação, o público é ciente ou ignora, dá atenção ou descuida, enfatiza ou negligencia elementos específicos dos cenários públicos. As pessoas tendem a incluir ou excluir dos próprios conhecimentos o que a mídia inclui ou exclui do próprio conteúdo. Além disso, o público tende a conferir ao que ele inclui uma importância que reflete de perto a ênfase atribuída pelos meios de comunicação de massa aos acontecimentos, aos problemas, às pessoas (SHAW, 1979, p.96 apud WOLF, 2003, p.143)

De acordo com esta hipótese, na análise do corpus ampliado, podemos identificar, com o passar do tempo, uma redução das publicações a respeito do Mais Médicos nos dois veículos. Nos meses iniciais do programa toda a mídia nacional estava concentrada no assunto; isto direcionava o interesse do público, o que impulsionava o debate. Aos poucos foi se esgotando o repertório sobre o tema, a mídia foi ficando inerte e, consequentemente a população não mais tinha o programa como tópico de suas discussões na esfera pública. Vejamos exemplos nos quadros seguintes, onde temos em 
uma coluna os títulos das matérias e em outra a quantidade de textos publicados por mês. São 122 textos retirados do Portal Médico e 93 retirados do site Pragmantismo Político.

\section{Quadro 5 - Um ano de Mais Médicos no Portal Médico}

CRMs vão ter nomes de quem supervisiona o Mais Médicos 29/07/2014

Justiça federal determina prazo para envio de informações do Mais Médicos ao CRM-MT 24/07/2014

Conselho Federal de Medicina reitera apoio ao projeto Saúde +10 22/07/2014

CFM denuncia ameaça à formação médica por políticas públicas 21/07/2014

Artigo de conselheiro no Estadão afirma que Mais Médicos é eleitoreiro 18/07/2014

Editorial da Folha de S. Paulo critica proliferação de escolas médicas 15/07/2014

MPT instaura inquérito para apurar denúncias contra o Provab 12/06/2014

Ministro da saúde não quis enfrentar médicos e acadêmicos 12/06/2014

Entidades Médicas de Mato Grosso do Sul entregam proposta de melhoria na saúde aos presidenciáveis Eduardo Campos e Aécio Neves 06/06/2014

Cubanos abandonam programa reclamando de falta de pagamento 04/06/2014

CFM alerta para a importância de medidas que garantam o bom funcionamento do SUS 20/05/2014

Nova edição do Jornal Medicina expõe o caos na rede pública de assistência à saúde 05/05/2014

Entidades médicas de Goiás anunciam mobilização em defesa da classe médica 07/04/2014

Volume de recursos enviados à OPAS supera montante destinado aos hospitais federais INCA E INTO 04/04/2014

Campo Grande será sede do Fórum Nacional do Ensino Médico nesta sexta-feira 03/04/2014

Artigo na Folha de S. Paulo alerta para jogada de marketing do Mais Médicos 31/03/2014

Cubanos fogem da Bolívia e pedem asilo no Brasil 27/03/2014

STJ proíbe médicos uruguaios de trabalhar em Santa Vitória do Palmar (RS) 19/03/2014

Aumento do valor da bolsa não põe fim nas irregularidades, diz CFM 28/02/2014

Jornal Nacional reforça críticas ao programa do Governo 28/02/2014

Academia de Medicina de São Paulo promove Fórum para debate do Programa Mais Médicos

20/02/2014

Mais Médicos promove o "neoescravagismo" no Brasil, diz ives Gandra 17/02/2014

Controle do governo falha no Mais Médicos 17/02/2014

Portaria do Mais Médicos reforça teoria de trabalho escravo, denuncia Fenam 14/02/2014

Ministério público do trabalho vai denunciar ilegalidades no Mais Médicos 13/02/2014

Mais três cubanos na BA, PE e MA abandonam programa do governo 12/02/2014

Ministério público diz que médica Cubana tem razão e que salário deve ser pago na íntegra 07/02/2014

CFM encaminha esclarecimentos em resposta a publicações equivocadas sobre o Mais Médicos

$17 / 01 / 2014$

CFM é contra a revisão das atuais diretrizes do curso de medicina 16/01/2014

CFM disponibiliza vídeos com críticas ao Mais Médicos 05/12/2013

Integrante do Mais Médicos apresenta críticas à Plenária do CFM 04/12/2013

CRM-MT promove encontro com médicos de Barra do Garças nesta sexta-feira (29) 27/11/2013

Profissional integrante do Mais Médicos faz críticas ao programa em audiência no STF 26/11/2013

Representantes do CFM, AMB e Ministério Público do Trabalho apontam equívocos do Mais Médicos 25/11/2013

Conselho Federal de Medicina participa de audiência pública sobre Mais Médicos no STF 25/11/2013

Tribunal de Contas da União aponta irregularidade em contrato do Mais Médicos 22/11/2013

Conselho Regional de Medicina de Mato Grosso promove nova reunião de aproximação com médicos do interior 21/11/2013

OMS e OIT recebem denúncia de ilegalidades no recrutamento de profissionais estrangeiros do 
programa Mais Médicos 21/11/2013

Conselheiros do CFM participam de audiência no STF para discutir legalidade do Mais Médicos $13 / 11 / 2013$

Jornal Medicina do mês de outubro destaca subfinanciamento da saúde pública 08/11/2013

Vereadores de porto Velho homenageiam médicos e chamam atenção para maior valorização do profissional 07/11/2013

MP vai questionar contratação pelo Mais Médicos 06/11/2013

Polícia Federal combate fraude na revalidação de diplomas em MT e mais 13 estados 01/11/2013

CFM defende aprovação em Revalida para dar segurança ao paciente 01/11/2013

CFM envia nota de esclarecimento à categoria 30/10/2013

CRM-MT promove encontro com médicos de Primavera do Leste 30/10/2013

Recolhimento da Previdência eleva impacto fiscal do Mais Médicos 29/10/2013

"Mais Médicos" pode ser alternativa para reprovados no Revalida, suspeita CFM 29/10/2013

Governo quebra acordo com base aliada e não com CFM 24/10/2013

Conselheiros da área de saúde prestam apoio ao CFM contra o Mais Médicos 23/10/2013

FBAM manifesta apoio às ações do CFM contra danos da MP $\overline{621 \text { 22/10/2013 }}$

WMA e Confemel criticam o programa Mais Médicos 17/10/2013

Residência Médica poderá ser tema principal do Fórum de Ensino Médico em 2014 16/10/2013

Nota de esclarecimento do Simepe sobre posicionamento do CFM 15/10/2013

CFM ajudou a reduzir danos causados pela MP 621 e não apoia "Mais Médicos", diz presidente $10 / 10 / 2013$

Pressão do CFM faz base aliada do governo recuar e aceitar melhorias na MP 621/2013 09/10/2013

Entidades conseguem fazer Mais Médicos progredir para Mais Saúde 08/10/2013

Profissionais do Mais Médicos no DF e Entorno encontram falta de estrutura 07/10/2013

CFM recorrerá a OMS contra contratação de médicos cubanos 03/10/2013

Supremo convoca audiência pública sobre programa Mais Médicos 02/10/2013

CFM aponta violação de direitos humanos na contratação de cubanos 02/10/2013

Entidades Médicas lamentam aprovação do relatório em Comissão Mista 01/10/2013

Justiça Federal concede liminar que dá direito ao Cremesp de deferir ou não registros a intercambistas 26/09/2013

CRMs cumprem a maioria dos prazos para emissão de registros provisórios a intercambistas estrangeiros 23/09/2013

Médicos divulgam resultado da Caravana da Seca 23/09/2013

Fenam contesta aprovação dos médicos com diplomas estrangeiros 20/09/2013

MAIS MÉDICOS: CRMs farão registros provisórios após entendimento da AGU na justiça 20/09/2013

Informações fundamentais para a fiscalização do Mais Médicos continuarão sendo exigidas, diz CFM $16 / 09 / 2013$

Comissão da Câmara analisa na próxima semana PEC que cria carreira de médico de Estado 12/09/2013

Liminar suspende obrigação de registrar médicos estrangeiros no CE 11/09/2013

Para segurança da população, Conselhos pedem ao governo dados sobre o Mais Médicos 10/09/2013

Equívocos do Mais Médicos são apontados pela AMBr na Câmara dos Deputados 09/09/2013

Presidentes dos CRMs do Brasil se reúnem no Cremepe 06/09/2013

Mesmo sob pressão, acadêmicos da UFMG mantém posição contrária à MP 621/13 06/09/2013

Fenam protocola denúncia e questiona o programa Mais Médicos junto ao TCU 05/09/2013

CFM esclarece situação de médico interditado cautelarmente selecionado pelo Mais Médicos 05/09/2013

Vereadores de Limeira repudiam revalidação automática de diplomas 03/09/2013

Análise do Conselho Federal de Medicina aponta queda acentuada de leitos no SUS desde 2010 03/09/2013

Ministério Público defende a aplicação do Revalida no "ㅆais Médicos" 02/09/2013

Entidades condenam acordos que abrem brechas à "semiescravidão" de médicos 28/08/2013

IV Congresso Brasileiro de Direito Médico debate o acesso à saúde 28/08/2013

CFM denuncia Governo Federal por restrição de liberdade de médicos cubanos 23/08/2013

Conselheiro rebate importação de médicos cubanos na Globonews e Band Entrevista 22/08/2013

Para CFM, importação de médicos cubanos é medida eleitoreira e irresponsável 21/08/2013 
Acamerj reitera posição contrária à MP 621/2013

CRMs vão à justiça pelo direito de não registar médicos sem diploma revalidado 14/08/2013

Gestores e tutores são corresponsáveis em denúncias envolvendo profissionais do "Mais Médicos" $13 / 08 / 2013$

Médicos pedem respeito ao Congresso e reforçam críticas ao Governo 10/08/2013

Vetos ao Ato Médico e MP 621/13 em debate no Encontro Nacional Extraordinário 09/08/2013

Entidades condenam Programa Mais Médicos 09/08/2013

Entidades médicas mobilizam o Congresso Nacional em Defesa da classe 08/08/2013

Médicos entregam aos parlamentares contrarrazões aos vetos à lei do Ato Médico e à MP 621/13 07/08/2013

Programa Mais Médicos é jogada eleitoreira, diz em Plenário senador Cyro Miranda 07/08/2013

Médicos brasileiros tentam, mas não conseguem ir para cidades no interior do país 06/08/2013

Jurista Miguel Reale Junior diz que Mais Médicos é demagogia na saúde 06/08/2013

MP do programa Mais Médicos já recebeu mais de 500 emendas no Congresso Nacional 02/08/2013

Ações jurídicas contra o programa Mais Médicos continuam em tramitação na Justiça Federal 02/08/2013

Para CFM, proposta do governo para a residência médica é temerária 01/08/2013

CFM denuncia falhas na plataforma de inscrições do Programa Mais Médicos 01/08/2013

Senadores apresentam mais de 200 emendas à MP do programa Mais Médicos 01/08/2013

31 de julho: Médicos de São Paulo na rua em defesa da saúde 30/07/2013

CFM aponta ilegalidades do programa ao Conselho do Ministério Público 30/07/2013

Para CFM, falta de garantias desestimula candidatos ao programa do Governo 29/07/2013

Universidades criticam proposta do governo por aumentar vagas em escolas médicas, sem garantir qualidade 29/07/2013

UFRN recusa imposição de adesão ao Mais Médicos 29/07/2013

AMB ajuíza segunda ação na justiça contra o programa Mais Médicos 29/07/2013

Mp do programa Mais Médicos já recebeu mais de 500 emendas na Câmara dos Deputados 26/07/2013

Médicos baianos se mobilizam com debate, panfletagem e feira de saúde, dias 30 e 31 26/07/2013

Academias de medicina repudiam a MP 621e os vetos à lei do Ato Médico 25/07/2013

AMB e Fenam também entram com ações na Justiça contra o Mais Médicos 24/07/2013

Justiça dá prazo de 72 horas para governo esclarecer Mais Médicos 24/07/2013

CFM entra com ação civil pública contra a União para suspender o programa Mais Médicos 22/07/2013

Entidades médicas confirmam saída das Câmaras e Comissões governamentais 19/07/2013

Comunicado importante da Associação Brasileira de Educação Médica (ABEM) 18/07/2013

Médicos e acadêmicos farão panfletagem nesta 5o feira em Goiânia 18/07/2013

Médicos voltam às ruas de todo o país contra medidas do Governo 17/07/2013

Imprensa critica MP dos Médicos importados e aponta falhas na estratégia 15/07/2013

Médicos fazem nova mobilização nesta terça-feira (16) contra medidas do Governo 15/07/2013

APM repudia improvisos apresentados pelo Governo Federal como remédio para o SUS 12/07/2013

Aprovada no Senado tramitação especial para criação da carreira de médico do Estado 10/07/2013

Manifestação do CRM-PR em resposta ao plano "Mais Médicos", do governo federal 10/07/2013

Cremego, AMG e Simego criticam programa Mais Médicos 09/07/2013

\section{Quadro 6 - Um ano de Mais Médicos no Pragmatismo Político}

Medicina é profissão com maior salário e menos profissionais 03/07/2013

"Um dia vai precisar da gente e vou lembrar de sua fisionomia" 05/07/2013

Servidores recebem extra e dinheiro do táxi para participar de protesto médico 05/07/2013

Filhos do presidente do Sindicato dos Médicos se formaram em Cuba 09/07/2013

Os médicos brasileiros têm medo de que? 09/07/2013

"Brasil precisa de médico especialista em gente" 09/07/2013

Especialistas elogiam programa Mais Médicos 10/07/2013

Drauzio Varella: sobre médicos estrangeiros no Brasil 11/07/2013

As regras do Revalida para estudantes brasileiros de Medicina 15/07/2013

Faltam 3 mil médicos na periferia de São Paulo 18/07/2013 
Só 5\% do estudantes de Medicina pretendem atender no interior do Brasil 18/07/2013 Importação de médicos: fatos que a imprensa omitiu 18/07/2013

Carta de um médico cubano: respeito, solidariedade e ética 19/07/2013

Mais Médicos segue recomendações da Organização Pan-America de Saúde 24/07/2013

Noruega elogia trabalho de Cuba na Haiti: 'maravilhoso' 25/07/2013

Cidade oferece R\$ 10 mil e estrutura, mas faltam médicos 30/07/2013

Reportagem flagra descaso médico repugnante na rede pública 31/07/2013

Brasileiros formados em Cuba destacam rompimento com a "ditadura do dinheiro" 01/08/2013

Mais Médicos tem adesão de 41 Universidades Federais 06/08/2013

Brasileiros aprovam contratação de médicos estrangeiros 12/08/2013

Duas médicas explicam porque aceitaram o Mais Médicos 13/08/2013

Médicos estrangeiros começam a trabalhar no Brasil em Setembro 15/08/2013

Maioria dos médicos cubanos vão para o norte e nordeste 23/08/2013

Médicos cubanos no Brasil: "viemos por solidariedade, não por dinheiro"25/08/2013

Cantanhêde ou Natasha Romero Sanches, quem é a escrava? 26/08/2013

Revista Veja aplaudiu médicos cubanos na época de FHC 26/08/2013

Vídeo: médicos brasileiros ofendem médicos cubanos 27/08/2013

Médicas "patricinhas" envergonham o Brasil 27/08/2013

"Vou orientar meus médicos a não socorrerem erros dos médicos cubanos" 27/08/2013

Jornalista diz que médicas cubanas "parecem empregadas domésticas" 27/08/2013

Os "escravos cubanos" perturbam os médicos brasileiros 27/08/2013

Médicos cubanos recebem flores um dia após agressões 28/08/2013

Negras médicas e domésticas 28/08/2013

Cubano xingado por jovens médicas brasileiras comenta o episódio 28/08/2013

O brasileiro de 77anos que está no Mais Médicos 28/08/2013

Como foi a primeira passagem dos cubanos no Brasil em 1999? 28/08/2013

Uruguaio do Mais Médicos faz seu primeiro atendimento 29/08/2013

Cubanos são os médicos mais respeitados em operações internacionais 29/08/2013

Conheça o médico que liderou os xingamentos contra cubanos 29/08/2013

Médicos cubanos não são escravos; entenda 30/08/2013

Médico brasileiro pego na mentira perde chance de ficar calado 30/08/2013

Curso de medicina no Brasil: so 2,6\% dos formados são negros 30/08/2013

Facebook desmascara denúncia da Folha sobre médicos 30/08/2013

Médicos brasileiros ofendem cubanos e retiram cama de dormitório 02/09/2013

"Brasil é medicalocêntrico", diz médica brasileira formada em Cuba 03/09/2013

Médica de BH vira as costas para profissionais estrangeiros 03/09/2013

"Médicos só vão a hospital se houver avião" 03/09/2013

Prefeituras estão proibidas de demitir médicos já contratados 03/09/2013

Vergonha de branco 03/09/2013

A comovente carta de desligamento da médica Rafaela Pacheco 04/09/2013

PSTU faz coro com a Veja e rejeita Mais Médicos 04/09/2013

Médicos recebem 16 mil mas não aparecem em hospital público 05/09/2013

Prefeito da cidade com pior IDH celebra chegada de médicos cubanos 05/09/2013

Medicina no Brasil é branca e classe média 06/09/2013

Geral Alckmin diz que "não faltam médicos" 06/09/2013

Lula sobre médicos cubanos: "deveriam ser parabenizados" 10/09/2013

Médicos estrangeiros são apoiados por 73,9\% dos brasileiros 10/09/2013

Jornalista que atacou médicas cubanas é processada 10/09/2013

Médicos cubanos são recepcionados com queijo e doce de leite 16/09/2013

Cubano símbolo do Mais Médicos cuidará de indígenas 25/09/2013

Opositor dos médicos cubanos renuncia mandato 01/10/2013

Cearenses contra médicos estrangeiros se filiam ao PSDB 04/10/2013

Médicos cubanos fazem sucesso no sertão nordestino 07/10/2013

Médicos pedem votos a pacientes contra Dilma 14/10/2013

Médicos cubanos salvaram milhares de vidas na Guatemala 21/10/2013

Dilma pede desculpas a médico cubano hostilizado no Brasil 22/10/2013

Médica brasileira: "revalida é feito para não aprovar ninguém" 25/10/2013 


\begin{tabular}{|c|c|}
\hline $\begin{array}{l}\text { Médico cubano no Brasil encante pacientes em posto de saúde 29/10/2013 } \\
\text { Médica cubana: "Dilma nos convocou para melhorar saúde do povo" 30/10/2013 }\end{array}$ & \\
\hline $\begin{array}{l}\text { Médico brasileiro que atacava cubanos é preso por só bater ponto } 07 / 11 / 2013 \\
\text { Pacientes do agreste agradecem "de joelhos" chegada de médicos cubanos } 11 / 11 / 2013 \\
\text { Médicas cubanas "provocam" paz provisória em zona de conflito na Bahia } 12 / 11 / 2013 \\
\text { Médica cubana utiliza "método diferente" em } 1^{\circ} \text { dia de trabalho } 13 / 11 / 2013 \\
\text { Mãe implora por retorno de médico cubano a comunidade 22/11/2013 } \\
\text { Por que a população brasileira passou a amar os médicos cubanos? 25/11/2013 } \\
\text { Médico cubano afastado volta ao trablaho e é recebido com festa 25/11/2013 } \\
\text { Pacientes do Mais Médicos não conseguem remédios em farmácia popular 26/11/2013 } \\
\text { A história do médico cubano sabotado por duas médicas brasileiras 29/11/2013 }\end{array}$ & 09 \\
\hline $\begin{array}{l}\text { Cubanos trazem ao Brasil uma nova forma de exercer Medicina 02/12/2013 } \\
\text { Os médicos cubanos na visão de um inglês que vive no Brasil 03/12/2013 }\end{array}$ & 02 \\
\hline Médica cubana que completa um mês no Brasil: "falta amor ao próximo" 31/01/2014 & 01 \\
\hline $\begin{array}{l}\text { Médica cubana que pediu ajuda ao DEM quer encontrar namorado em Miami 06/02/2014 } \\
\text { PSDB e DEM preferem tirar médicos do Brasil e levá-los a Miami 11/02/2014 } \\
\text { Conselho de Medicina quer que cubanos trabalhem para médicos brasileiros 13/02/2014 } \\
\text { A hipocrisia e o silência dos críticos do Mais Médicos 23/02/2014 }\end{array}$ & 04 \\
\hline $\begin{array}{l}\text { Cubana desertora do Mais Médicos tem liminar negada pela justiça 03/03/2014 } \\
\text { Casal de cubanos humilhados dá exemplo de solidariedade 03/03/2014 } \\
\text { Mais Médicos: } 4 \text { mil cubanos chegam ao Brasil nesta semana 06/03/2014 } \\
\text { "Escravidão?” O povo quer mais médico e menos demagogia 07/03/2014 }\end{array}$ & 04 \\
\hline $\begin{array}{l}\text { Corpo de médico cubano é encontrado em hotel de Brasília 01/04/2014 } \\
\text { Médica cubana conclui seu plano e consegue asilo nos EUA 03/04/2014 }\end{array}$ & 02 \\
\hline Globo é obrigada a reconhecer qualidade dos médicos cubanos 11/06/2014 & 01 \\
\hline Mais médicos, urgente! 22/07/2014 & 01 \\
\hline
\end{tabular}

Como afirma Cohen, se é verdade que a imprensa "pode não conseguir, na maior parte do tempo, dizer às pessoas o que pensar, por outro lado ela se encontra surpreendentemente em condições de dizer aos próprios leitores sobre quais temas pensar alguma coisa". (1963, p.13 apud Wolf, 2003, p. 143-4)

Para concluir, destaco a aproximação, tanto da Comunicação quanto da Análise de Discurso Crítica, dos estudos sociológicos. Essas três áreas do conhecimento se desenvolvem simultaneamente, com contribuições de umas para as outras. Por isso, é inconcebível estudar uma sem que exista qualquer tipo de contato com as outras. É nessa perspectiva que pretendo aqui iniciar uma triangulação entre as três bases teóricas, introduzindo o seguinte pensamento:

Sabemos que a ADC ocupa-se de efeitos ideológicos que sentidos de textos, como instâncias de discurso, possam ter sobre relações sociais, ações, interações, pessoas e mundo material. Suas preocupações 
direcionam-se a sentidos que possam atuar a serviço de projetos particulares de dominação e exploração, seja contribuindo para modificar ou sustentar, assimetricamente, identidades, conhecimentos, crenças, atitudes e valores. (RESENDE \& RAMALHO, 2011, p. 75)

É possível notar na explanação anterior a interdependência dessas três correntes teóricas, que possuem elementos de interseção, não se restringindo nenhum destes à apenas uma daquelas. Quando falamos em efeitos ideológicos, buscamos referências na teoria da ideologia. Porém, tais efeitos estão contidos em textos que são trabalhados pelos meios de comunicação de massa. Por conseguinte, esses textos são instâncias de discurso que refletem diversas interpretações sobre o mundo e suas relações intrínsecas. A seguinte observação de Thompson reforça esse pensamento:

Argumentarei que a midiação da cultura moderna - isto é, as maneiras como as formas simbólicas, nas sociedades modernas, tornaram-se crescentemente mediadas pelos mecanismos e instituições da comunicação de massa - é uma característica central da vida social moderna, e defenderei que uma análise satisfatória da ideologia em tais sociedades deve, por isso, estar baseada, ao menos em parte, numa compreensão da natureza e do desenvolvimento da comunicação de massa. (THOMPSON, 2011, p. 104-5)

Para compreendermos a natureza e o desenvolvimento da comunicação de massa, devemos ter em mente que as pesquisas em comunicação se dividem de momento a momento entre estudos sobre os meios de comunicação de massa e cultura de massa. Logo, destacamos mais uma vez a proximidade entre a teoria da ideologia, a ADC e as teorias da comunicação, visto que não podemos falar em cultura sem explorar aspectos da vida social, os meios pelos quais as formas simbólicas se distribuem e os potenciais efeitos ideológicos dessas interações na construção de discursos e consolidação de práticas.

Segundo Thompson (2011, p.11), “os escritores que se interessaram pelos problemas da ideologia não conseguiram tratar adequadamente a natureza e o impacto dos meios de comunicação no mundo moderno" e aqueles que olharam para os meios de comunicação de massa com mais atenção, olharam com uma perspectiva pessimista.

Eles tenderam a olhar o desenvolvimento dos meios de comunicação de massa como a emergência de um novo mecanismo de controle social nas 
sociedades modernas, um mecanismo através do qual as idéias dos grupos dominantes pudessem ser propagadas e difundidas e através do qual a consciência dos grupos dominados pudesse ser manipulada e controlada. A ideologia foi entendida como uma espécie de "cimento social", e os meios de comunicação de massa foram vistos como mecanismo especialmente eficaz para espalhar o cimento. (THOMPSON, 2011, p.11)

Seguindo esse pensamento elaborado por Thompson (2011), os modelos teóricos da comunicação de massa centrados nos efeitos a curto prazo seriam os que mais se afiliam à ideia do cimento social. Segundo Wolf (2003, p.4), a posição sustentada por esse modelo pode ser sintetizada com a afirmação de que "todo membro do público de massa é pessoal e diretamente 'atacado' pela mensagem” (Wright, 1975, p.79).

Estes são preceitos da Teoria Hipodérmica, que está relaciona com a difusão em larga escala das comunicações de massa. A Teoria Hipodérmica é uma abordagem global da mídia, indiferente à diversidade entre os vários meios, e que responde principalmente à interrogação: qual efeito tem a mídia numa sociedade de massa? Segundo Mauro Wolf:

"O pensamento político do século XIX, de cunho conservador, ressalta na sociedade de massa o resultado da crescente industrialização, da revolução nos transportes, no comércio, da difusão dos valores abstratos de igualdade e liberdade. Esses processos sociais determinam a perda de exclusividade por parte das elites, que se encontram expostas às massas. $O$ enfraquecimento dos vínculos tradicionais (de família, de comunidade, de associações profissionais, de religião etc.) contribui, por sua parte, para afrouxar o tecido conectivo da sociedade e para preparar as condições para o isolamento e a alienação das massas". (WOLF, 2003, p.6)

Portanto, em uma sociedade de massa, a mídia tem o papel de homogeneizar os pensamentos e padronizar comportamentos. O enfraquecimento dos vínculos tradicionais criou terreno propício para a implementação de pensamentos uniformes e consequente manipulação dos modos de agir. Nesse sentido fala-se da comunicação como instrumento eficiente para espalhar o cimento social que seria a ideologia. 


\title{
CAPÍTULO 3 - TEORIAS E METODOLOGIAS DE PESQUISA
}

Nesta etapa exploro as teorias e metodologias que consolidam esta pesquisa. Inicio descrevendo a abordagem teórico-metodológica proposta por Chouliaraki e Fairclough (1999). Em seguida, esclareço a identificação e descrição do problema de pesquisa apresentando o corpus principal e alguns detalhes sobre sua delimitação. O capítulo é finalizado com a explanação das categorias linguístico-discursivas aplicadas nas análises que serão empreendidas no Capítulo 4.

\section{1 - Abordagem teórico-metodológica do estudo qualitativo documental}

Como já vimos, “a proposta de abordagem teórico-metodológica da ADC fornece subsídios para a realização de pesquisas qualitativas cujo principal material empírico são textos, sejam documentos oficiais, entrevistas, reportagens, textos publicitários, dentre tantos outros tipos de texto passíveis de serem materiais de pesquisa em ADC" (RAMALHO \& RESENDE, 2011, p. 73), de acordo com o que foi mencionado no Capítulo 1.

\begin{abstract}
Nesse passo, a ADC oferece ferramentas analíticas para o pesquisador mapear conexões entre aspectos sociais semióticos e não-semióticos, tendo em vista dois objetivos principais. Primeiro, investigar mecanismos causais discursivos e seus efeitos potencialmente ideológicos. Segundo, refletir sobre possíveis maneiras de superar relações assimétricas de poder parcialmente sustentadas por sentidos de textos. De acordo com o princípio da profundidade ontológica, entendese que o trabalho de descrição e interpretação de conexões, em termos de causa e efeito, entre linguagem e sociedade não pode ser feito, de maneira satisfatória, apenas com base em análises qualitativas de textos. (RAMALHO, 2008, p.136)
\end{abstract}

A pesquisa qualitativa se caracteriza por ter base interpretativa, o que possibilita, de forma não-contraditória, que sobre um mesmo texto sejam feitas análises distintas. Sobre o assunto, Fairclough (2003a, p.14) esclarece que "não devemos presumir que a realidade de textos seja exaurida por nosso conhecimento sobre eles. Não pode haver análises textuais "completas" e "definitivas", ou "objetivas" e "imparciais", por serem inevitavelmente seletivas, ou seja, em toda análise, escolhemos responder a determinadas questões sobre eventos sociais e textos, e não a outras questões possíveis”. Segundo Fairclough, essa característica não compromete a cientificidade das análises textuais, mas aponta as limitações desse tipo de trabalho isolado. 
Atualmente, a pesquisa qualitativa se mostra promissora, passando a ser aceita gradativamente no meio científico como tipo de pesquisa que pode, em sua essência, ter elevado rigor científico e gerar diferentes perspectivas. Portanto, a pesquisa qualitativa pode ser tão ou mais rigorosa do ponto de vista científico quanto à pesquisa quantitativa.

\begin{abstract}
Ainda que os métodos qualitativos priorizem a interpretação de dados, não possuem o monopólio da abordagem interpretativa, visto que métodos quantitativos também exigem interpretação de dados. A polêmica entre duas tradições de pesquisa social, aparentemente competitivas, é estéril, porque se trata de duas tradições que se complementam. Ambas, além de envolverem processos interpretativos, buscam a qualificação. Na verdade, não há quantificação sem qualificação (BAUER, GASKELL E ALLUM, 2002: 22-5)
\end{abstract}

Para Flick (2002, p. 20), “a pesquisa qualitativa consiste na escolha correta de métodos e teorias oportunos, no reconhecimento e na análise de diferentes perspectivas, nas reflexões dos pesquisadores a respeito de sua pesquisa como parte do processo de produção de conhecimento". Dessa forma,

O processo da pesquisa qualitativa envolve três conjuntos interligados de decisões, relacionadas à ontologia, epistemologia e metodologia. Segundo Dezin \& Lincoln (2006, p. 32-3), o/a pesquisador/a, situado/a biograficamente, "aborda o mundo com um conjunto de idéias, um esquema (teoria, ontologia) que especifica uma série de questões (epistemologia) que ele então examina em aspectos específicos (metodologia, análise". (RAMALHO \& RESENDE, 2011, p. 74)

Nessa perspectiva, Chouliaraki \& Fairclough (1999, p. 60) oferecem um arcabouço teórico-metodológico inspirado no Realismo Crítico que, em síntese, abrange o problema (a vida social traduzida pelo discurso); os obstáculos à sua resolução (análises da conjuntura, da prática discursiva e do discurso); a função do problema na prática; os possíveis meios de sobrepujar os obstáculos; e a reflexão sobre a investigação empreendida, como sintetiza o quadro seguinte. 
Quadro 7 - Arcabouço teórico-metodológico da ADC

\begin{tabular}{|l|}
\hline Percepção de um problema social com aspectos semióticos \\
\hline $\begin{array}{c}\text { Identificação de obstáculos para que o problema seja superado } \\
\text { análise da conjuntura } \\
\text { análise da prática particular } \\
\text { análise do discurso }\end{array}$ \\
\hline Investigação da função do problema na prática \\
\hline Investigação de possíveis modos de ultrapassar os obstáculos \\
\hline Reflexão sobre a análise \\
\hline
\end{tabular}

Ramalho (2008, p.137)

Essa proposta para explanação crítica de fenômenos sociais, pela investigação de mecanismos que os produzem, compõe-se de cinco etapas principais. De acordo com Fairclough (2003a: 15), para ter acesso a efeitos ideológicos de textos, é preciso relacionar a "microanálise" de textos à "macroanálise" de maneiras como relações de poder operam através de redes de práticas e estruturas. Por isso, as cinco etapas do arcabouço, descritas a seguir, conjugam análises textual e socialmente orientadas.

Pesquisas orientadas pela ADC partem da identificação de um problema social com aspectos semióticos. Definida a preocupação de pesquisa, segue-se à identificação de elementos que representam obstáculos para a superação do problema, por meio de três tipos de análise: análise da conjuntura, análise da prática particular e análise do discurso. Esses três tipos de análise podem especificar obstáculos para que o problema em foco seja superado. Nas duas primeiras análises, investigam-se redes de práticas (ou conjunturas) em que se localiza o problema de cunho semiótico, assim como a prática particular em estudo, o que inclui análise de relações dialéticas entre discurso e outros momentos (não-discursivos).

$\mathrm{Na}$ análise do discurso, em que textos figuram como principal material empírico, pesquisam-se conexões entre mecanismos discursivos e o problema em foco. A análise detalhada e intensiva de textos como elementos de processos sociais é, nos termos de Chouliaraki \& Fairclough (1999: 67), um processo complexo que engloba duas partes: a compreensão e a explanação. Um texto pode ser compreendido de diferentes maneiras, uma vez que diferentes combinações das propriedades do texto e do posicionamento social, conhecimentos, experiências e crenças do leitor resultam em diferentes 
compreensões. Parte da análise de textos é, portanto, análise de compreensões, que envolvem descrições e interpretações. A outra parte da análise é a explanação, que reside na interface entre conceitos e material empírico. Esta constitui um processo no qual propriedades de textos particulares são "redescritas" com base em um arcabouço teórico particular, com a finalidade de "mostrar como o momento discursivo trabalha na prática social, do ponto de vista de seus efeitos em lutas hegemônicas e relações de dominação".

Além de englobar essas duas partes, compreensão e a explanação, a análise de discurso é orientada, simultaneamente, para a estrutura e para a interação. Isto é, para os recursos sociais (ordens de discurso) que possibilitam e constrangem a interação, bem como para as maneiras como esses recursos são articulados em textos. A concepção de textos como parte de eventos específicos, que envolvem pessoas, (inter)ação, relações sociais, mundo material, além de discurso, situa a análise textual na interface entre ação, representação e identificação, os três principais aspectos do significado. Este tipo de análise, segundo Fairclough (2003a: 28), implica uma perspectiva social detalhada de textos. Permite não só abordar os textos "em termos dos três principais aspectos do significado, e das maneiras como são realizados em traços dos textos", mas também fazer "a conexão entre o evento social concreto e práticas sociais mais abstratas", pela investigação dos gêneros, discursos e estilos utilizados, e das maneiras como são articulados em textos.

As duas etapas seguintes do arcabouço correspondem a investigações sobre as funções do problema na prática, e às possíveis maneiras de superar os obstáculos identificados em fase anterior. O objetivo é identificar mecanismos que sustentam o aspecto problemático em uma prática particular, tendo em vista a possibilidade de superálo. Por fim, o arcabouço propõe uma reflexão sobre a análise e sua contribuição para questões de emancipação social.

Conforme essa abordagem de pesquisa proposta por Chouliaraki e Fairclough (1999), na qual o trabalho se inicia com a percepção de um problema social com aspectos semióticos, o debate acerca da aceitação do Programa Mais Médicos incentivou uma reflexão mais profunda sobre a questão do serviço de saúde brasileiro. As formas pelas quais os meios de comunicação representaram o programa e seus/suas profissionais refletiram aspectos da vida social. $\mathrm{O}$ acesso à saúde, as condições de trabalho, o salário, as práticas médicas e o conceito de medicina em si foram alvos de acirradas discussões. No cerne das negociações, um problema urgia por solução: a falta de médicos/as em localidades distantes dos grandes centros. 
A inquietude ao perceber que o foco do "problema" saúde estava sendo desviado para outras direções - políticas, econômicas, mercadológicas etc - e a falta de solidariedade percebida nos discursos de combate ao Programa Mais Médicos impulsionaram esta pesquisa qualitativa, pois, como definem Dezin \& Lincoln (2006, p. 32-3), "pesquisas qualitativas são, por princípio, interpretativas, isto é, guiadas por um conjunto de crenças e de sentimentos em relação ao mundo e ao modo como este deveria ser compreendido e estudado" (apud Resende e Ramalho, 2011, p. 74). Além disso, como bem observa Flick (2002, p. 17), "a relevância específica da pesquisa qualitativa para o estudo das relações sociais deve-se ao fato da pluralização das esferas da vida”.

\begin{abstract}
"A palavra qualitativa implica uma ênfase sobre as qualidades das entidades e sobre os processos e os significados que não são examinados ou medidos experimentalmente (se é que são medidos de alguma forma), em termos de quantidade, volume, intensidade ou frequência. Os pesquisadores qualitativos ressaltam a natureza socialmente construída da realidade, a íntima relação entre o pesquisador e o que é estudado, e as limitações situacionais que influenciam a investigação. Esses pesquisadores enfatizam a natureza repleta de valores da investigação. Buscam soluções para as questões que realçam o modo como a experiência social é criada e adquire significado. Já os estudos quantitativos enfatizam o ato de medir e analisar as relações causais entre variáveis, e não processo" (DENZIN; LINCOLN, 2006 p. 23).
\end{abstract}

De acordo com Flick (2002, p. 17), "existe atualmente, uma enorme variedade de métodos específicos disponíveis, cada um dos quais partindo de diferentes premissas em busca de objetivos distintos". Considerando que pesquisas qualitativas em ADC podem ser orientadas, epistemologicamente, por diferentes abordagens, como a etnográfica e a documental, o estudo aqui proposto segue predominantemente a abordagem documental, qual seja, aquela que utiliza como principal material empírico dados de natureza formal, como textos midiáticos, jurídicos, oficiais, entre outros, cuja elaboração demanda competência de conhecimento especializado.

Desse modo, o corpus principal de análise foi constituído por doze textos elaborados em contextos socio-históricos diferenciados, mas com lastro nas competências específicas de seus produtores. Em resumo, são produções jornalísticas de grandes veículos nacionais ou textos originários do corpo médico brasileiro. Contudo, de modo complementar, serão utilizados textos formais que oferecem subsídio para a amarração das ideias explanadas neste trabalho, como o código de ética do médico. 
Ainda, de forma auxiliar, serão empreendidas análises complementares de cunho quantitativo que contribuirão para uma visão mais abrangente e darão suporte às explanações propostas pela pesquisa. São dados relevantes que agregam significado aos resultados perseguidos.

\section{2 - O diagnóstico}

O presente trabalho teve início a partir do momento em que o Programa Mais Médicos foi lançado. Na tentativa de impedir sua concretização, a classe médica fez um diagnóstico da saúde brasileira e iniciou a prescrição das medidas “mais próprias” a serem tomadas. No entanto, sua atitude se revelou um tanto quanto protetora de interesses pessoais, o que abriu nossos olhos para o tema e despertou a curiosidade para explorar os meandres da profissão e sua rede de práticas consolidadas. Assim, como observam Resende e Ramalho:

A primeira tarefa que se impõe ao/à investigador/a em pesquisas qualitativas é, portanto, a definição de sua concepção de mundo, ou da natureza da realidade (ontologia). Segundo Mason (2002), a definição clara da ontologia que orienta um projeto de investigação deve ser o primeiro passo em qualquer pesquisa, pois os pressupostos ontológicos determinam as decisões de cunho epistemológico e metodológico. (RESENDE \& RAMALHO, 2011, p.75)

Considerando que a ontologia se refere a conceitos e termos que podem ser usados para descrever alguma área do conhecimento ou construir uma representação desse, pressupomos que antes disso devemos observar o mundo a nossa volta para, então, podermos interpretá-lo a fim de encontrar alternativas para possíveis transformações. Assim, esta pesquisa assume a postura ontológica crítico-realista que pretende compreender quais são os indícios do que é real e do que acreditamos poder ser.

\section{3 - Os pacientes}

Como material empírico, a primeira fonte de pesquisa está no endereço 'www.pragmatismopolítico.com.br'. Nele encontramos matérias escritas por profissionais de diversas áreas; jornalistas, professores, médicos, advogados, enfim, pessoas comprometidas em escrever sobre assuntos de seus domínios. O site é 
colaborativo e está aberto para a participação de todos. Em sua página inicial visualizamos a distinção das seguintes editorias: Porões da Ditadura, Educação, Cultura, Eleições 2014, Saúde e Mídia. Para a seleção do material de análise foi feita uma busca pela expressão "Mais Médicos" na parte do site destinada à Saúde. Como resultado foram encontradas 93 matérias sobre o assunto. Esta opção foi baseada na amplitude de temas explorados pelo site. Naturalmente, se fizéssemos uma busca geral pelo tema Mais Médicos, seríamos destinados à seção sobre saúde.

A segunda fonte de pesquisa está no endereço 'portal.cfm.org.br/'. Abertamente o conteúdo presente nesta plataforma é de relevante interesse para a classe médica. Como possui finalidade institucional, sua tela inicial é dividida nas seguintes categorias: Sobre o CFM, Conselheiros, Transparência, LegislaçãoไProcesso, Serviços, Cidadão, Educação e Comunicação. Desta vez a seleção do material foi feita através de uma busca geral pela expressão "Mais Médicos" dentro do portal. Foram encontrados 122 textos a respeito do programa. A opção por esta forma de busca se justifica por se tratar de um veículo que reúne apenas temas relacionados à medicina.

O período selecionado para coleta de material está compreendido entre julho de 2013 e julho de 2014, o que nos permite perceber eventuais mudanças discursivas no decorrer de um ano do Programa Mais Médicos. Durante esses doze meses de análise, foram selecionados os três primeiros textos e os três últimos de cada plataforma, totalizando doze textos a serem analisados. O intuito é observar as avaliações feitas sobre o programa logo após seu surgimento e as variações discursivas apresentadas após um ano de discussão. A seguir, temos um quadro-resumo dos textos selecionados. Nele encontramos a manchete da matéria, o dia de publicação e a autoria do texto.

Quadro 8 - Quadro resumo do corpus principal da pesquisa

QUADRO RESUMO DO CORPUS PRINCIPAL DA PESQUISA

TEXTO 1 - "CRMS VÃO TER NOMES DE QUEM SUPERVISIONA O MAIS MÉDICOS" (Estado de S. Paulo, publicado em 29/07/2014)

TEXTO 2 - "CONSELHO FEDERAL DE MEDICINA REITERA APOIO AO PROJETO SAÚDE+10" (Conselho Federal de Medicina, publicado em 22/07/2014) 
TEXTO 3 - "CFM DENUNCIA AMEAÇA À FORMAÇÃO MÉDICA POR POLÍTICAS PÚBLICAS" (Conselho Federal de Medicina, publicado em 21/07/2014)

TEXTO 4 - "APM REPUDIA IMPROVISOS APRESENTADOS PELO GOVERNO FEDERAL COMO REMÉDIO PARA O SUS” (Associação Paulista de Medicina, publicado em 11/07/2013)

TEXTO 5 - "MANIFESTAÇÃO DO CRM-PR EM RESPOSTA AO PLANO "MAIS MÉDICOS", DO GOVERNO FEDERAL" (Conselho Federal de Medicina, publicado em 10/07/2013)

TEXTO 6 - "CREMEGO, AMG E SIMEGO CRITICAM PROGRAMA MAIS MÉDICOS" (Conselho Regional de Medicina do Estado de Goiás, publicado em 09/07/2013)

TEXTO 7 - "MAIS MÉDICOS, URGENTE!" (Mauro Donato, DCM, publicado em $\underline{\underline{22 / 07 / 2014)}}$

TEXTO 8 - “GLOBO É OBRIGADA A RECONHECER QUALIDADE DOS MÉDICOS CUBANOS” (Pragmatismo Político, publicado em 11/06/2014)

TEXTO 9 - "MÉDICA CUBANA CONCLUI SEU PLANO E CONSEGUE ASILO NOS EUA" (Brasil 247, publicado em 03/04/2014)

TEXTO 10 - "OS MÉDICOS BRASILEIROS TÊM MEDO DE QUÊ?" (Ricardo Palácios*, publicado em 09/07/2013)

TEXTO 11 - "SERVIDORES RECEBEM EXTRA E DINHEIRO DO TAXI PARA PARTICIPAR DE PROTESTO MÉDICO” (Renato Rovai, em seu Blog, publicado em $05 / 07 / 2013$ )

TEXTO 12 - "MEDICINA É PROFISSÃO COM MAIOR SALÁRIO E MENOS PROFISSIONAIS" (Pragmatismo Político, publicado em 03/07/2013)

Apreciações pontuais de outros textos poderão ser cometidas a fim de corroborar as interpretações manifestadas. Além da análise das matérias jornalísticas, fará parte do estudo um levantamento de dados e documentos importantes para a compreensão das avaliações desenvolvidas. O código de ética do médico, por exemplo, é um documento que presta ajuda fundamental para a apreensão da atuação moderna da medicina brasileira. A seguir, quadro-resumo do corpus ampliado. 
Quadro 9 - Quadro-resumo do corpus ampliado

\begin{tabular}{|l|}
\hline \multicolumn{1}{|c|}{ CORPUS AMPLIADO } \\
\hline Código de Ética Médico \\
\hline Juramento de Hipócrates \\
\hline Medida Provisória $\mathrm{N}^{\circ}$ 621 de 8 de julho de 2013 \\
\hline Portal do Mais Médicos \\
\hline
\end{tabular}

E não só em teóricos da $\mathrm{ADC}$ este trabalho se ampara. Buscando uma maior compreensão dos fenômenos midiáticos, será imprescindível resgatar teóricos da Comunicação com suas formulações sobre os efeitos dos meios de comunicação de massa e todas as implicações decorrentes desses estudos. Nomes como Mauro Wolf, Theodor Adorno e Umberto Eco contribuirão para solidificar as bases deste estudo.

\section{4 - As categorias linguístico-discursivas de análise}

Para persecução do objetivo mais geral, algumas categorias de análise foram selecionadas a fim de estabelecer da forma mais produtiva as relações entre o material empírico (textos) explorado e as significações dele apreendidas. Dessa forma, serão desenvolvidos os conceitos de intertextualidade, interdiscursividade, recursos de legitimação e representação de atores sociais.

\subsection{1 - Intertextualidade}

Bakhtin (2000, p.308) afirma que cada enunciado "é um elo na cadeia de comunicação". Os enunciados ou os textos são constituídos por elementos de outros textos, inerentemente intertextuais, pois todos os enunciados são constituídos, preenchidos com palavras de outros que podem se apresentar mais ou menos explícitos ou completos.

Para Bakhtin, todos os enunciados, tanto na forma oral quanto na escrita, do mais breve turno numa conversa a um artigo científico ou romance, são demarcados por uma mudança de falante (ou de quem escreve) e são orientados retrospectivamente para enunciados de falantes anteriores (sejam eles turnos, artigos científicos ou romances) e prospectivamente para enunciados antecipados de falantes seguintes. (FAIRCLOUGH 2001, p. 134) 
O estudo da intertextualidade é de grande relevância para a Análise de Discurso Crítica. Implica reconhecer as vozes que são representadas nos textos e se os sentidos ali impressos podem ser realmente atribuídos a seus autores. Fairclough (2001, p.114) define intertextualidade como a "propriedade que têm os textos de ser cheios de fragmentos de outros textos, que podem ser delimitados explicitamente ou mesclados e que o texto pode assimilar, contradizer, ecoar ironicamente, e assim por diante". Dessa forma, os textos podem transformar textos anteriores e reestruturar as convenções existentes (gêneros, discursos) para produzir novos textos. Mas essa produtividade na prática é socialmente limitada e condicionada às relações de poder. Nesse sentido, a teoria da intertextualidade não pode explicar essas limitações sociais, e assim ela precisa ser combinada com uma teoria de relações de poder e de como elas moldam estruturas e práticas sociais, e são, por sua vez, moldadas por elas.

\begin{abstract}
A intertextualidade é uma questão de recontextualização, ou seja, um movimento de um contexto a outro, acarretando transformações particulares dependendo de como o material é movimentado, recontextualizado, de como ele figura no novo contexto. Dado que práticas sociais encerram diferentes discursos e interesses particulares, a presença de uma voz específica, de maneiras específicas, em vez de outras, sinaliza o posicionamento do texto nas lutas de poder. A seleção das vozes nessa recontextualização, bem como as maneiras como elas são representadas, diz muito sobre o posicionamento político desse evento discursivo na rede de práticas sociais. (RAMALHO, 2005, p. 93-4)
\end{abstract}

Segundo Fairclough (2003a: 41-2), a análise do aspecto intertextual de um texto deve ser orientada pela observação da abertura ou fechamento da diferença, ou seja, pela observação de variados graus de dialogicidade com as vozes recontextualizadas, uma vez que "toda enunciação, mesmo na forma imobilizada da escrita, é uma resposta a alguma coisa e é construída como tal. Não passa de um elo da cadeia de atos de fala" (BAKHTIN, 2002, p. 98). Logo, “o ouvinte que recebe e compreende a significação de um discurso adota simultaneamente, para com este discurso, uma atitude responsiva ativa: ele concorda ou discorda [...], completa, adapta, apronta-se para executar, etc.” (BAKHTIN, 1997, p. 290). Sendo assim, por meio da observação das escolhas lingüísticas feitas pelo locutor para representar o discurso do outro, é possível analisar seu grau de engajamento com o que enuncia, em sua atitude responsiva ativa, ou seja, se ele concorda, discorda ou polemiza outros atos de fala da rede de práticas sociais. 
Fairclough (2001, p. 137) estabelece que "a intertextualidade implica uma ênfase sobre a heterogeneidade dos textos e um modo de análise que ressalta os elementos e as linhas diversos e frequentemente contraditórios que contribuem para compor um texto". Ele recorre aos estudos de Bakhtin e Kristeva e considera pontos dos estudos dos analistas de discurso franceses, como a intertextualidade manifesta e a intertextualidade constitutiva, a qual chamará de interdiscursividade. De acordo com Fairclough (2001, p.152), "a intertextualidade manifesta é o caso em que se recorre explicitamente a outros textos específicos em um texto, enquanto interdiscursividade é uma questão de como um tipo de discurso é constituído por meio de uma combinação de elementos de ordens de discurso." Vejamos a seguir um melhor detalhamento desta distinção:

\subsubsection{1 - Intertextualidade Manifesta}

Como vimos, na intertextualidade manifesta outros textos estão expressamente presentes no texto sob análise: eles estão "manifestamente" marcados ou sugeridos na superfície do texto. Fairclough discute a intertextualidade manifesta em relação a cinco aspectos:

1) Representação de discurso: o autor usa o termo "representação do discurso" em lugar do termo tradicional "discurso relatado". Assim, pode-se perceber que existe uma relação dinâmica entre as vozes do discurso representado e representador. O limite entre eles é parcialmente uma questão de escolha entre representação direta ou indireta do discurso. Ou seja, diz respetio aos conceitos de intertextualidade manifesta e constitutiva, respectivamente traduzidas por intertextualidade e interdiscursividade. A representação direta reproduz as palavras exatas usadas no discurso representado. Geralmente é marcada por aspas. O discurso indireto, ao contrário, é ambivalente: não se pode ter certeza que as palavras do original são reproduzidas ou não. Nesse caso, a escolha do verbo representador, ou o verbo do "ato da fala" é sempre significativa. É comum o uso de verbos como 'disse', 'falou', 'alertou', 'assinalou', que marcam a força ilocucionária do discurso representado, o que é uma questão de impor uma interpretação para o discurso representado. 
2) Pressuposição: são proposições tomadas pelo produtor do texto como já estabelecidas ou "dadas". Verbos como 'esquecer', 'lamentar' e 'perceber' marcam pressuposições. Por exemplo: "Eu esqueci que ele já tinha voltado de férias" pressupõe que a pessoa tinha saído de férias. Artigos definidos também indicam proposições que têm significados "existenciais". Por exemplo: "A ação midiática e eleitoreira criada na divulgação do plano 'Mais Médicos' somente demonstra o descompasso do atual governo com as reais necessidades da população". Nesse caso, toma-se como fato definido que o programa foi criado com fim eleitoreiro e baseado numa campanha da mídia para sustentá-lo. Segundo Fairclough (2001), pela dificuldade de desafiá-las, as pressuposições são formas concretas de manipular as pessoas.

Fairclough (2003a) distingue a pressuposição da citação direta ou indireta de vozes por meio do fechamento da diferença que a pressuposição representa. A intertextualidade apresenta abertura para a diferença, enquanto que a pressuposição a reduz. A opção mais dialógica é a atribuição explícita a outras vozes, a inclusão de algumas das muitas vozes existentes por meio da citação, o que acentua a diferença. A opção menos dialógica, por sua vez, que anula diferenças entre a voz do locutor e a voz externa recontextualizada e que, portanto, sugere alto grau de engajamento com o que se enuncia, é a pressuposição. Assim como a intertextualidade, a pressuposição conecta um texto a outros textos, no entanto, a pressuposição não é atribuída a vozes ou textos específicos. A intertextualidade pode sinalizar abertura e reconhecimento da diferença ou acentuação conflituosa da mesma, ao passo que a pressuposição aponta para o consenso, normalização e aceitação, suprimindo diferenças de poder (FAIRCLOUGH, 2003ª , p.478). Nas palavras de Ramalho (2005, p. 95), “a medida do sucesso da universalização de uma representação do mundo diz respeito ao quanto figura como dado em uma variedade de textos, logo a análise das pressuposições pode desvelar posicionamentos ideológicos naturalizados pela sua repetição em discursos".

3) Negação: contesta ou rejeita outros textos. Ao dizermos, por exemplo, "O governo federal apresentou um programa chamado Mais Médicos, que tende a não solucionar o problema do atendimento do SUS, nem a curto nem a longo prazo, porque não enfoca a principal questão, que é o financiamento insuficiente", estamos pressupondo que existe um outro texto o qual afirma que o Programa Mais Médicos solucionará os problemas de atendimento no SUS a curto prazo. Portanto, as frases negativas carregam tipos especiais de pressuposição que também funcionam intertextualmente. 
4) Metadiscurso: possibilita o controle dos diferentes discursos dentro do texto. Há várias formas de se conseguir isso, como o uso de expressões evasivas (espécie de, tipo de), o uso de paráfrase ou a reformulação de uma expressão. O metadiscurso implica que o falante esteja situado acima ou fora de seu próprio discurso e esteja em uma posição de controlá-lo e manipulá-lo.

5) Ironia: acontece quando um enunciado ecoa outro enunciado, havendo uma disparidade entre o significado a que se dá voz e a função real do enunciado que foi ecoado. Para o reconhecimento da ironia é necessário que os intérpretes sejam capazes de reconhecer que o significado de um texto ecoado não é o significado do produtor do texto.

\subsubsection{2 - Interdiscursividade}

A intertextualidade constitutiva ou interdiscursividade de um texto pode ser considerada como a incorporação das relações complexas que têm com as convenções (gêneros, discursos, estilos, tipos de atividades) que estão estruturadas juntas e constituem uma ordem de discurso. A interdiscursividade estende a intertextualidade em direção à ordem de discurso, que tem primazia sobre os tipos particulares de discurso, que são constituídos como configuração de elementos diversos de ordens de discurso (FAIRCLOUGH, 2001). A interdiscursividade se aplica a vários níveis: a ordem de discurso societária, a ordem de discurso institucional, o tipo de discurso, e mesmo os elementos que constituem os discursos, como por exemplo: o discurso médico, o discurso jornalístico, o discurso acadêmico.

A ordem de discurso institucional tem uma configuração particular de gêneros em relações particulares uns com os outros, constituindo um sistema. Essa configuração de gêneros caracteriza a interdiscursividade. Além disso, a configuração e o sistema estão abertos à mudança, para serem redesenhados à medida que as ordens de discurso são desarticuladas e rearticuladas em novas ordens. Isso pode afetar apenas a ordem de discurso 'local' de uma instituição, ou pode transcender a instituição e afetar a ordem de discurso societária. 


\subsubsection{3 - Representação de atores sociais}

Retomo aqui esta categoria linguístico-discursiva já trabalhada no Capítulo 2. Trata-se de perceber como os participantes/atores de práticas sociais podem ser representados no discurso. Essa representação passa por uma questão gramatical que entende-se por um sistema de escolhas de significados potenciais. São os modos pelos quais atores podem ser representados.

Portanto, analisarei no Capítulo 4 quais atores sociais e em que contextos são representados como "agentes" e como "pacientes", por exemplo. Quais vozes são articuladas e quem são os atores responsáveis por elas. Cada uma dessas escolhas representacionais propostas estão ligadas a realizações linguísticas ou retóricas específicas. E mais, o significado é cultural e não definido pela língua: não pode ser associado a uma semiótica específica.

A rede de sistemas de escolhas de representação de atores sociais abrange uma variedade de fenômenos linguísticos e retóricos, tendo como elemento centralizador o conceito de "ator social". As representações incluem ou excluem atores sociais para servir aos seus interesses e propósitos em relação aos leitores a que se dirigem. Algumas exclusões podem ser "inocentes", outras estão relacionadas com a estratégia de amoldamento de significados.

Como exemplo, posso citar as categorias de representação chamadas assimilação e individualização. A primeira representa os atores sociais como grupos, na segunda, os atores são representados como indivíduos. Assim, no caso do Programa Mais Médicos, percebemos a utilização dessas categorias a depender da avaliação feita por quem se pronuncia. O Portal Médico, na maioria de seus textos, representa os/as médicos/as cubanos/as por assimilação. Quando individualiza um/a desses/as atores/as, é na tentativa de exemplificar "falhas" do programa.

\subsubsection{4 - Ideologia e construções simbólicas}

Segundo Thompson, o conceito de ideologia tem sido considerado, predominantemente, de duas maneiras: ou é tido como um sistema de idéias (os 'ismos' socialismo, liberalismo, etc), ou é considerado muito ambíguo e, por isso, abandonado. Para recuperar esse campo essencial às suas proposições, ele estuda as várias fases do conceito e seus contextos teóricos e sócio-históricos. Nesse percurso, o autor retoma o 
termo 'ideologia', tal como foi apresentado por pensadores como Destutt de Tracy, Marx, Lenin, Lukács, Mannheim e outros. A partir dessa revisão, constrói a sua concepção especial de ideologia ou concepção crítica: "ideologia é sentido a serviço do poder". Ou seja, estudar ideologia é compreender e explicar as maneiras pelas quais as formas simbólicas são usadas para a implantação e para a manutenção de relações de dominação. Nesse sentido, estamos falando do potencial ideológico de determinados sentidos, ou seja, sua capacidade de orientar modos de agir e sedimentar práticas sociais à serviço da manutenção de assimetrias de poder.

Cabe destacar que, apesar de manter a negatividade do conceito, acompanhando Marx, retira-lhe o caráter 'ilusório'. Como fala em uso de formas simbólicas, dirige o fenômeno ideológico ao campo mais amplo da cultura e de suas construções de sentido. Nessa direção, revisa o conceito de cultura e, do mesmo modo que descrevemos acima, retira desse procedimento uma concepção diferenciada e operante. É a concepção estrutural de cultura, a qual define a análise cultural desse modo: "o estudo da constituição significativa e da contextualização social das formas simbólicas".

Podemos, pois, resumir um importante aspecto dessa discussão, articulando esses conceitos com o trabalho de Fairclough (2001). Ele nos fala da relação dialética entre estrutura social e discurso. O discurso é moldado pela estrutura social, mas é também socialmente constitutivo. O mesmo se pode dizer, concordando com Thompson, das formas simbólicas em geral, e da ideologia em particular.

A ideologia está relacionada, desse modo, a uma determinada estrutura social, mas, por outro lado, é igualmente constitutiva dessa estrutura. Uma vez que se tenha presente esse processo, pode-se entender a importância que Thompson credita ao desenvolvimento dos meios de comunicação de massa, bem como a oportunidade do seu conceito de mediação da cultura moderna : "o processo geral através do qual a transmissão das formas simbólicas se tornou sempre mais mediada pelos aparatos técnicos e institucionais das indústrias da mídia" (Thompson, 2011, p. 37).

O desenvolvimento da 'mass media' está ligado ao surgimento do capitalismo e ao incremento dos meios técnicos relacionados à produção, transmissão e recepção de formas simbólicas. É extremamente relevante porque representa tanto uma transformação das próprias formas simbólicas quanto uma alteração dos contextos sociais dessas formas.

Logo, podemos pensar que a evolução dos meios técnicos de transmissão das formas simbólicas fortalecem os potenciais ideológicos na medida em que o alcance das representações da realidade se expande. Representações essas que se realizam de variadas 
maneiras na tentativa de orientar o pensamento de quem as recebe para um sentido específico e não outro.

Ao determinar que o estudo das formas simbólicas é considerado inevitavelmente um problema de compreensão e interpretação, Thompson (2011) trata de evitar o que chama de a 'tentação' de reduzi-las a 'objetos naturais', passíveis de análise formal, estatística e objetiva. Esse posicionamento deve-se ao fato de considerar que o objeto dessas investigações é, ele mesmo, um território pré-interpretado.

A partir dos conceitos desenvolvidos neste capítulo darei início no capítulo seguinte às análises dos textos do corpus principal como forma de materializar e sistematizar as teorias até agora explanadas nesta dissertação. 


\section{CAPÍTULO 4 - ANÁLISE DO CORPUS PRINCIPAL}

Neste capítulo, serão apresentadas as análises dos discursos representados nos textos do portal do CFM e do site Pragmatismo Político. A ordem dos textos selecionados está do mais recente para o mais antigo, dentro do conjunto referente a cada veículo. Primeiramente serão trabalhados os textos do CFM e, na sequência, os do Pragmatismo Político. A fim de sistematizar a leitura, optei por arranjar o material da seguinte forma: após cada matéria será feita a análise, de maneira que fique mais prático para o leitor retornar ao texto e identificar a parte onde se encontra o trecho de referência. A título de apresentação, ressaltarei algumas características dos textos de cada veículo.

No portal do Conselho Federal de Medicina, podemos identificar que a maioria das produções são de entidades vinculadas ao CFM, sendo apenas um texto originário de um grande veículo da imprensa brasileira. O Texto 1 foi retirado do jornal impresso Estado de S. Paulo. O Texto 2 e o Texto 3 são produções do setor responsável pela comunicação do CFM. O Texto 4 foi produzido pela Associação Paulista de Medicina APM. O Texto 5 e o Texto 6 foram escritos respectivamente pelo CFM e pelo Conselho Regional de Medicina do Estado de Goiás - Cremego. 


\section{1 - TEXTO 1 - “CRM's VÃO TER NOMES DE QUEM SUPERVISIONA O MAIS MÉDICOS (Estado de S. Paulo, publicado em 29/07/2014)}

Figura 1 - Texto 1 - CRM's vão ter nomes de quem supervisiona o Mais Médicos CRMs vão ter nomes de quem supervisiona o Mais Médicos

\section{冚国}

Ter, 29 de Julho de 2014 09:45

Conselhos de Mato Grosso e Mato Grosso do Sul conseguem decisão favorável da Justiça; debate começou em 2013

Os Conselhos Regionais de Medicina (CRMs) de Mato Grosso e Mato Grosso do Sul ganharam na Justiça o direito de ter o nome dos profissionais que fazem a tutoria e a supervisão dos intercambistas do Mais Médicos. Esses órgãos pediram ao ministério a relação dos profissionais, mas o pedido nunca foi atendido. O Conselho Federal de Medicina (CFM) afirma que outras regionais entraram com ações semelhantes.

O presidente do CFM, Roberto d'Ávila, disse considerar essenciais essas informações para que regionais tenham condições de fazer a fiscalização das atividades. "Recebemos números gerais, mas é preciso saber onde estão os supervisores e tutores, até mesmo para averiguar se estão próximos dos intercambistas", disse.

A decisão de Mato Grosso do Sul foi concedida pelo juiz federal Pedro Pereira dos Santos, da $4^{\star}$ Vara de Campo Grande. Em Mato Grosso, a decisão foi dada pelo juiz llan Presser. "Acreditamos que essas duas medidas vão abrir caminho para decisões semelhantes em outros Estados", afirmou.

D'Ávila disse que, desde que o programa teve início, no ano passado, conselhos regionais pedem informações para o ministério. "A resposta, sempre padrão, era a de que a lei não obrigava a pasta a prestar tais esclarecimentos", disse. "Sem tais informações, não podemos fazer a fiscalização adequada." D'Ávila afirmou que os dois Estados, a partir de agora, poderão empenhar-se em avaliar quantos tutores e supervisores trabalham diretamente com médicos do programa federal, como é feito 0 acompanhamento e, sobretudo, a formação dos profissionais. "O intercâmbio pressupõe aprendizado."

Ele afirma que os conselhos não fazem fiscalizações de cursos voltados para médicos brasileiros. "Mas eles têm perfil diferente São vinculados a universidades, a centros de ensino. No caso de residências, tal fiscalização não é necessária, porque são médicos já formados."

Notificação. O Ministério da Saúde informou que não havia sido notificado sobre as decisões de Mato Grosso e Mato Grosso do Sul até $o$ início da noite de ontem. Afirmou, no entanto, que a pasta cumpre todas as determinações da lei do Mais Médicos. No texto, prossegue, não há nada que obrigue o governo a informar nomes de tutores e supervisores.

No ano passado, a Advocacia-Geral da União (AGU) chegou a ingressar com uma representação na Procuradoria-Geral da República (PGR), solicitando investigação dos CRMs

Fonte: Estado de S. Paulo, publicado em 29/07/2014
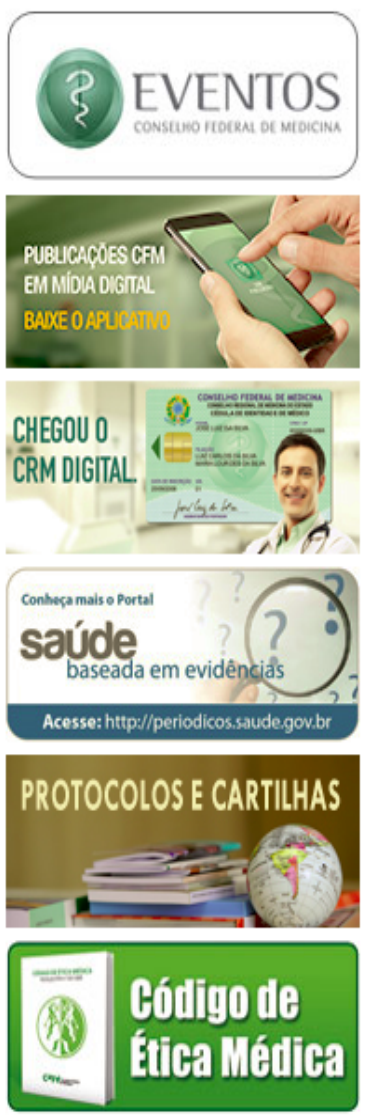

Código de Processo

Ético Profissional

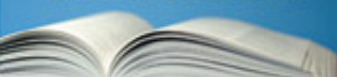

Conforme discutido na seção 2.3, o modo de operação da ideologia denominado fragmentação diz respeito ao processo de desagregação de pessoas ou grupos que possam se constituir como potencial ameaça aos grupos dominantes. Materialmente, em textos esse modo de operação da ideologia tende a se manifestar por meio das categorias 'diferenciação' e ‘categorização'. Esta última, conforme Leeuwen (2007) subdivide-se em 'funcionalização' e ‘identificação'.

No texto 1 podemos perceber a utilização de 'nomeações' e 'categorizações'. Os atores sociais representados por meio da nomeação não são, ou não exercem função de médicos. Dois deles são juízes e o outro, apesar de ser médico, atua no caso como presidente do CFM e fiscal do Programa Mais Médicos. Também verificamos que a ‘fragmentação' foi realizada por meio da 'categorização' por 'identificação', como mostraremos nos exemplos seguintes. 


\section{Exemplo (1)}

“O presidente do CFM, Roberto d'Ávila, disse...”. (Nomeação)

"A decisão de Mato Grosso do Sul foi concedida pelo juiz federal Pedro Pereira dos Santos, da $4^{\text {a }}$ vara de Campo Grande. Em Mato Grosso, a decisão foi dada pelo juiz Ilan Presser". (Nomeação)

É compreensível que a estruturação e conteúdo do texto possibilite a nomeação apenas de alguns atores, porém, as categorizações que foram feitas dos demais participantes deixam clara a intenção de desqualificar o/a médico/a estrangeiro/a enquanto assegura posição de superioridade ao/à médico/a brasileiro/a. De três referências aos/às médicos/as estrangeiros/as (Leia-se, cubanos/as!), em duas eles/as foram referidos/as como intercambistas. Na terceira, como médicos/as do programa federal.

Exemplo (2)

(...) profissionais que fazem a tutoria e a supervisão dos intercambistas do Mais Médicos. (...) (Identificação) (Identificação)

(...) até mesmo para averiguar se estão próximos dos intercambistas, (...)

(...) tutores e supervisores trabalham diretamente com médicos do programa federal, (...) (Identificação)

Duas observações podem ser feitas. Primeiro, que o texto representou os/as médicos/as estrangeiros/as apenas como intercambistas, fazendo parecer que estão destituídos/as dos postos de médicos/as, conforme ilustra o Exemplo 2. Quando identificados como intercambistas, os/as médicos/as cubanos/as já são colocados em um grupo à parte, com direitos e deveres diferenciados de outros/as médicos/as do programa.

Segundo, quando se fala em fiscalizar os/as médicos/as do programa federal, aqui estão incluídos/as médicos/as brasileiros/as. Mas eles/as precisam de fiscalização? Segundo o texto analisado o presidente do CFM afirma que os conselhos não fazem fiscalizações de cursos voltados para médicos/as brasileiros/as.

\section{Exemplo (3)}

Roberto D’Ávila: “Mas eles (médicos brasileiros) têm perfil diferente. São vinculados a universidades, a centros de ensino. No caso de residências, tal fiscalização não é necessária, porque são médicos já formados". 
Este último período ressalta a representação do/a médico/a estrangeiro/a como não-formado/a, desqualificado/a, portanto, digno/a de fiscalização. Aqui a fragmentação se manifesta de forma mais latente na tentativa do expurgo do outro. Cria-se um inimigo, um lado mau que, portanto, precisa ser eliminado.

Retomando o conceito de categorização, destacamos a existência de dois tipos fundamentais na concepção de van Leeuwen para o termo: funcionalização e identificação. No texto 1, a funcionalização não seria suficiente para categorizar os/as médicos/as, visto que dentro do grupo 'médicos' estão brasileiros/as e estrangeiros/as. Portanto, a categorização empregada foi por identificação. De um lado coloca-se os médicos/as cubanos/as, do outro, os/as brasileiros/as.

De forma similar, podemos identificar também a categoria chamada 'diferenciação'. O texto diferencia explicitamente um grupo de atores sociais de outro grupo semelhante, criando a diferença entre os outros (médicos/as cubanos/as) e nós (médicos/as brasileiros/as). Essa forma de construção simbólica auxilia o modo de operação da ideologia conhecido como 'fragmentação'. A partir da estratégia descrita como o 'expurgo do outro', é desenvolvida a ideia de dois lados opostos que se enfrentam. Para Thompson (2011, p. 87), “essa estratégia envolve a construção de um inimigo, seja ele interno ou externo, que é retratado como mau, perigoso e ameaçador e contra o qual os indivíduos são chamados a resistir coletivamente ou a expurgá-lo". 


\section{2 - TEXTO 2 - CONSELHO FEDERAL DE MEDICINA REITERA APOIO AO PROJETO SAÚDE + 10 (Conselho Federal de Medicina, publicado em 22/07/2014)}

\section{Figura 2 - Texto 2 - Conselho Federal de Medicina reitera apoio ao projeto saúde +10}

\section{Conselho Federal de Medicina reitera apoio ao projeto Saude+10}

Ter, 22 de Julho de 2014 10:47

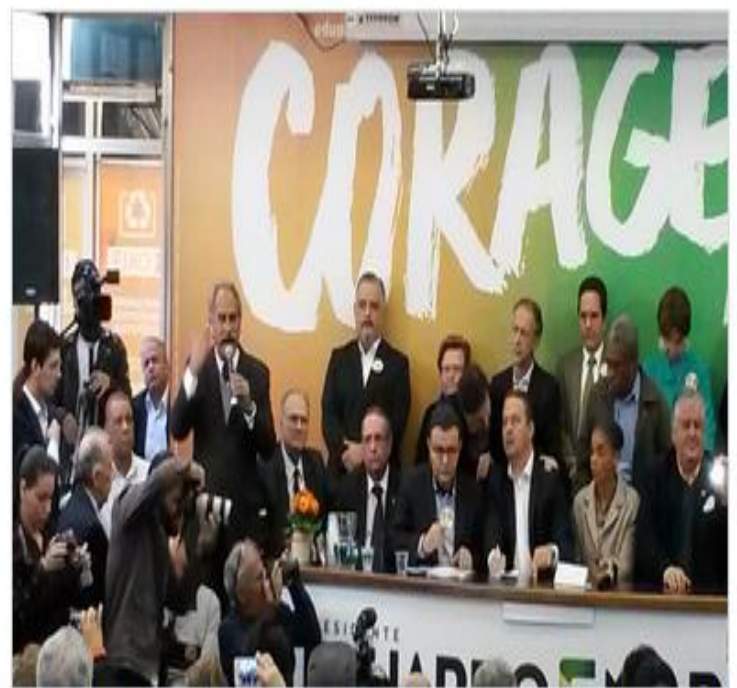

CFM reitera apoio à maior vinculaçăo de repasses para financiamento da rede pública
0 Conselho Federal de Medicina (CFM) reiterou seu apoio ao projeto Saúde +10 , que prevêe 0 aumento da vinculação de repasses da União para o financiamento da rede pública no país. A confirmação do engajamento a esta proposta ocorreu durante a inauguração do Comitê Central da campanha do candidato do PSB à Presidência da República, Eduardo Campos. Na solenidade, realizada em São Paulo, o presidente do CFM, Roberto Luiz d'Avila, discursou em nome de todas as entidades e grupos da sociedade civil organizada que têm apoiado à proposta $\mathrm{e}$ que ajudaram a juntar mais de dois milhões de assinaturas que viabilizaram o projeto de iniciativa popular sobre 0 tema.

"A saúde passa por um momento de crise profunda. Precisamos de mais recursos e também de melhor gestão para tornar o SUS uma realidade", enfatizou d'Avila. Em sua participação, ele lembrou que a grande maioria dos 400 mil médicos querem mudança na forma de fazer política no Brasil e esperam contribuir para esta renovação ocorra. "Cada um tem o direito de expressar sua posição ideológica. No entanto, as pesquisas mostram que a população exige mudanças na gestão pública", lembrou.

Pessoal - Roberto d'Avila ressaltou que seu posicionamento é de caráter pessoal, mas recomendou aos colegas que evitem apoio a lideranças ou politicos que não expressem compromisso com a saúde e que tenham optado pelo caminho de tornar o médico culpado pelos numerosos problemas na assistência. Acompanhado pela sua vice, Marina Silva, o ex-governador Eduardo Campos elogiou o posicionamento do presidente do CFM e assumiu o compromisso de, se eleito, discutir pontos importantes para a gestão da saúde no Brasil.

Segundo ele, há dinheiro no Orçamento da União para melhorar o investimento na assistência, como quer o movimento Saúde † 10. Outras metas são a criação de uma carreira pública para o médico do SUS e o estabelecimento de canais de diálogo com as entidades representativas da categoria para encontrar respostas aos problemas que afligem 0 atendimento e 0 ensino médico. "Vamos fazer uma política pública com os médicos, respeitando os direitos", disse. "É dizer sim à saúde, e não ao desperdicio, à corrupção", acrescentou.

Em seu discurso, Campos voltou a criticar o Mais Médicos, uma das bandeiras do atual Governo. "Nunca imaginei que era possivel fazer uma politica pública de saúde criminalizando os médicos ou jogando o povo contra os médicos brasileiros. Vamos fazer uma politica pública com os médicos, com todos os profissionais de saúde, formando brasileiros no interior do Brasil para cuidar dos brasileiros; ampliando, nas universidades públicas, a formaç̧ão, não só na graduação, mas nas especialidades que 0 Brasil precisa. E em debate com suas entidades, respeitando o que há de organizado, e não impondo à sociedade, como se faz quando os governos não acreditam no diálogo."
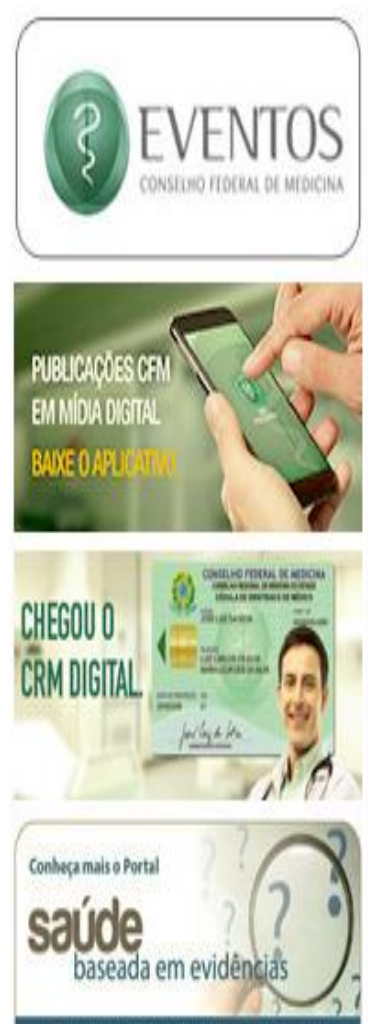

Acesse: hitipi/periodicossudegovbr
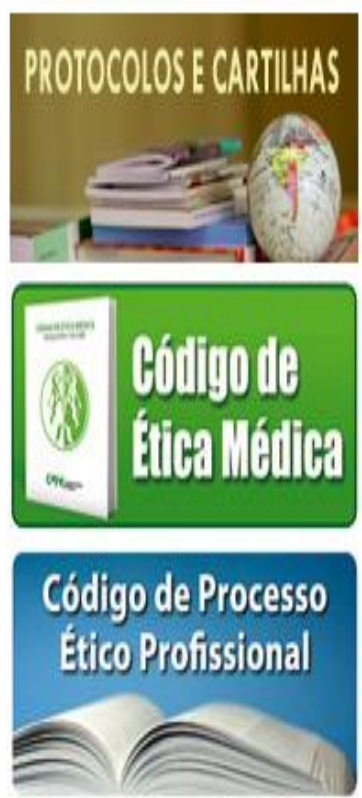

REGRAS DA

PUBLICIDADE MÉDICA 
O Texto 2 tem caráter notadamente político. Em sua maior parte, propõe outro modelo de programa de saúde e antecipa algumas características, colocando-o como mais eficiente que o Programa Mais Médicos. Enquanto critica a saúde pública brasileira que, como se pode notar, ainda não atingiu nível satisfatório, o representante da classe médica se engaja na campanha do candidato à Presidência pelo PSB, e este retribui com promessas de olhar atentamente a saúde caso seja eleito. Ao final, o candidato Eduardo Campos comenta o Programa Mais Médicos e adianta algumas propostas referentes à saúde.

Para garantir a força da palavra impressa no Texto 2, o autor utiliza a 'nomeação' como principal categoria de representação de atores sociais. Conforme apresentado na subseção 2.2.2 do Capítulo 2, a nomeação se dá quando os atores são representados em termos de sua identidade única, recebendo, assim, um papel de maior importância no texto. Realiza-se tipicamente através de nomes próprios. Porém, podem ocorrer sob a forma de honorificação, adição de títulos padrão, cargos etc. Conforme veremos no exemplo seguinte, o Texto 2 faz uso desses variados tipos.

\section{Exemplo (4)}

"A confirmação do engajamento a esta proposta ocorreu durante a inauguração do Comitê Central da campanha do candidato do PSB à Presidência da República, Eduardo Campos. Na solenidade, realizada em São Paulo, o presidente do CFM, Roberto Luiz d'Ávila, discursou..." (Nomeação)

\section{Exemplo (5)}

"Acompanhado pela sua vice, Marina Silva, o ex-governador Eduardo Campos elogiou o posicionamento do presidente do CFM..." (Nomeação)

\section{Exemplo (6)}

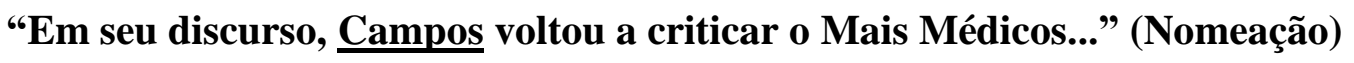

No Texto 2 também identificamos a 'intertextualidade'. De acordo com a Seção 3.4.1.1, na qual destacamos cinco apectos da intertextualidade, resgatarei aqui a noção da representação de discurso. A partir de uma nomeação que utiliza o nome próprio do autor da fala, o texto representa o discurso do presidente do CFM, que percebemos pelo emprego dos verbos de atos da fala 'enfatizou' e 'lembrou'. Logo, temos uma 
intertextualidade manifesta representada por meio de um discurso direto, como ficou claro no capítulo anterior.

\section{Exemplo (7)}

"A saúde passa por um momento de crise profunda. Precisamos de mais recursos e também de melhor gestão para tornar o SUS uma realidade", enfatizou d'Ávila. Em sua participação, ele lembrou que a grande maioria dos 400 mil médicos querem mudança na forma de fazer política no Brasil e esperam contribuir para que esta renovação ocorra. (Intertextualidade)

Esse exemplo nos mostra a abertura para a diferença no discurso. A fala representada trabalha uma avaliação negativa que pertence ao presidente do CFM. O texto representa o discurso por meio dos verbos de atos da fala sublinhados, marcando claramente o ator que se pronuncia. Dentro desse discurso, Roberto d' Ávila faz uso de uma 'assimilação' para dizer que os/as médicos/as estão unidos pela mudança na forma de fazer política no Brasil. Quando ele fala na "maioria dos 400 mil médicos" a tendência é acharmos que há um consenso e que a categoria está realmente determinada a fazer política. 


\section{3 - TEXTO 3 - CFM DENUNCIA AMEAÇA À FORMAÇÃO MÉDICA POR POLÍTICAS PÚBLICAS (Conselho Federal de Medicina, publicado em 21/07/2014)}

\section{Figura 3 - Texto 3 - CFM denuncia ameaça à formação médica por políticas públicas}

CFM denuncia ameaça à formação médica por políticas públicas

Seg, 21 de Julho de 2014 14:38

Criação de novas vagas em cursos de medicina no País põe em risco padrão alcançado no cenário internacional

A criação de 13 novos cursos de medicina, com a abertura de 570 vagas, só no primeiro semestre de 2014, põe em alerta as entidades médicas. A preocupação é tema do artigo $O$ futuro da saúde em risco, publicado na edição desta segunda-feira (21) do jornal Folha de S. Paulo.

$\mathrm{O}$ assunto foi analisado pelos conselheiros Roberto Luiz d'Avila, presidente do Conselho Federal de Medicina (CFM): Carlos Vital Tavares Corrêa Lima, $1^{\circ}$ vice-presidente; e Mauro Britto, conselheiro federal pelo Mato Grosso do Sul e representante do Conselho na Comissão Nacional de Residência Médica. O texto aponta a necessidade "de uma ação responsável do Estado para resgatar a qualidade do ensino médico e da assistência na rede pública".

$\mathrm{O}$ artigo remete à série de preocupações sobre o futuro da saúde no Brasil, após um ano de criação do Programa Mais Médicos. $\mathrm{A}$ análise chama a atenção para a necessidade de avaliação da competência dos intercambistas estrangeiros, por estar em jogo a segurança de milhares de pacientes.

Confira abaixo a íntegra do texto:

O futuro da saúde em risco

Escrito por Roberto Luiz d'Avila*, Carlos Vital ${ }^{\star \star}$ e Mauro Britto ${ }^{\star \star \star *}$

O Brasil depende de uma ação responsável do Estado para resgatar a qualidade do ensino médico e da assistência na rede pública

Ao final de seu primeiro ano, o programa Mais Médicos deixa no ar uma série de preocupações sobre o futuro da saúde no Brasil $\mathrm{Em}$ relação à assistência, de forma urgente, o país deve estar atento à necessidade de avaliação da competência dos intercambistas estrangeiros. Afinal, está em jogo a segurança de milhões de pacientes.

Ao aprovar a lei $n^{0} 12.871 / 13$, o governo federal tornou possível que portadores de diplomas obtidos no exterior pudessem atuar sem antes mostrarem sua capacidade. Contudo, as denúncias de equívocos que se acumulam evidenciam que os riscos são muitos e que o marketing nem sempre resolve tudo.

Buscar a revalidação dos diplomas dos intercambistas é um caminho para qualificar o atendimento. $O$ governo não pode esquecer a temporariedade da iniciativa e precisa definir já uma fórmula para ampliar a cobertura assistencial, especialmente no interior distante.

Dirigentes da Organização Mundial da Saúde alertam: medidas desse tipo não podem ser definitivas ou de longo prazo. É urgente a implementação de propostas que efetivamente atraiam e levem os médicos brasileiros para as áreas de difícil provimento. Uma delas é a criação de carreiras de Estado no SUS (Sistema Único de Saúde) para médicos e outras categorias (enfermeiros, dentistas e farmacêuticos)

Ao oferecer as condições ideais desse tipo de contratação, o Estado beneficiará, sobretudo, a população desfavorecida, que contará com profissionais estimulados, infraestrutura adequada e equipes completas. As preocupações, no entanto, não se limitam ao campo assistencial.

A qualidade da formação dos futuros médicos também está sob ameaça. Chama atenção a quantidade de novos cursos médicos no Brasil. Em 24 anos, o número passou de 83 para 235 (aumento de $283 \%$ ). Desde 2011, passaram a funcionar 58 deles (53\% privados).

Esse quadro deixa o país no ranking mundial atrás apenas da Índia, que tem população seis vezes maior que a nossa e 381 escolas. Por ano, os 235 cursos em funcionamento no Brasil ofertam 20.539 novas vagas. Nos Estados Unidos, por exemplo, que têm $50 \%$ a mais de habitantes, esse total é de 17.364 , distribuídas entre 141 escolas.

No Brasil, apesar de ilhas de excelência, a falta de critérios tem feito com que escolas funcionem com estruturas limitadas, sem laboratórios, sem hospitais de ensino e sem professores especialistas, mestres ou doutores. A intenção do governo federal de oferecer 11.447 novas vagas de graduação em medicina até 2018 amplifica o sinal de alerta.

O governo alega que esse aumento de vagas fixará médicos em áreas de difícil provimento. Trata-se de argumento falacioso. Estudos mostram que só $26 \%$ dos médicos fixam residência nos municípios de sua graduação. A permanência ocorre de forma significativa nos locais onde é feita a especialização. Sem atentar para esses aspectos, a proposta tem tudo para dar errado.

Além disso, causam inquietude as mudanças das diretrizes curriculares aprovadas pelo Conselho Nacional de Educação, que priorizaram o internato dos alunos na rede pública. $\mathrm{Na}$ prática, estudantes poderão ser treinados até em postos de saúde. Sem estrutura nem professores em condições de proporcionar essa formação, a iniciativa camufla a real intenção do governo: suprir a carência do SUS com mão de obra barata.
? EVENTOS
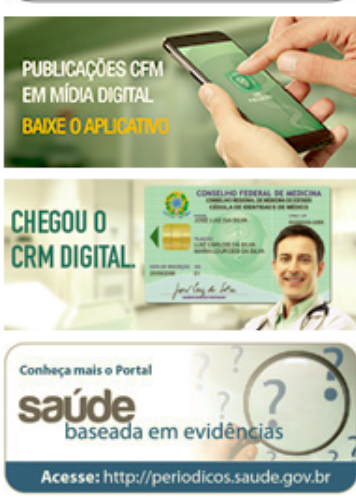

PROTOCOLOS E CARTILHAS

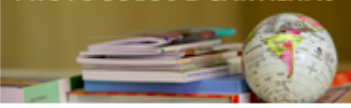

Bódigo de

Etica Múdica

Código de Processo

Ético Profissional

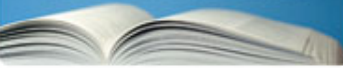

REGRAS DA PUBLICIDADE MÉDICA
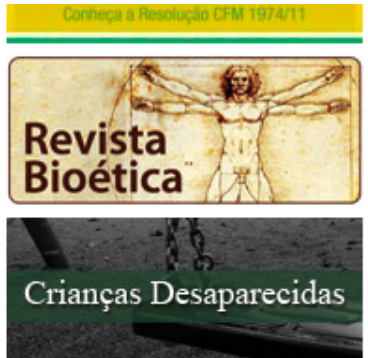

Enfrente - Grack!

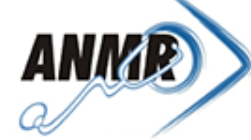


Esses dilemas afetam os programas de residência médica. A oferta de uma vaga de especialização para cada formando, anunciada pelo Ministério da Educação, é inexequível. Não há hospitais preparados nem preceptores suficientes para orientar os futuros especialistas.

As medidas anunciadas para a assistência e o ensino da medicina nada têm de estruturantes. São açodadas e pecam por não enfrentar 0 debate com segmentos interessados --profissionais, universidades e a Comissão Nacional de Residência Médica. Preocupa-nos o futuro. O Brasil tem urgência em ser bem tratado e, para tanto, depende de uma ação responsável do Estado para encontrar, em parceria com a sociedade, as respostas que resgatarão a qualidade do ensino médico e da assistência na rede pública.

*É presidente do Conselho Federal de Medicina (CFM)

** $1^{\circ}$ vice-presidentedo CFM

${ }^{\star \star \star}$ Conselheiro federal pelo Mato Grosso do Sul e representante do CFM na Comissão Nacional de Residência Médica.

No Texto 3 teremos duas etapas de análises. Primeiro falarei a respeito da introdução ao artigo em comento. Em seguida, analisarei o artigo foco da publicação.

Dentre outras categorias de análise já trabalhadas nesta pesquisa, o Texto 3 se destaca pela utilização de 'pressuposições'. O título da matéria juntamente com seu subtítulo nos leva a crer que o ensino da medicina no Brasil alcançou um padrão internacional de qualidade e que este está sendo ameaçado pela criação de novas vagas em cursos de medicina. Ou seja, a ameaça existe e o CFM a denuncia.

Além disso, o texto se refere a um "padrão internacional de qualidade" que não leva em consideração características específicas nacionais. Esta descontextualização nos impede de compreender o que representa tal padrão, determinando apenas que ele existe e deve ser perseguido por quem almeja reconhecimento nesse meio profissional. Vejamos no exemplo seguinte.

\section{Exemplo (8)}

“CFM DENUNCIA AMEAÇA À FORMAÇÃO MÉDICA POR POLÍTICAS PÚBLICAS". "Criação de novas vagas em cursos de medicina no País põe em risco padrão alcançado no cenário internacional”. (Pressuposição)

A introdução também faz algumas nomeações que dão voz a representantes da classe médica. No entanto, exclui outras vozes que, da mesma maneira, têm relevância no debate em questão. O Exemplo 2 deixa clara a intenção de realçar um posicionamento de combate a ações do Governo, colocando apenas os representantes de Conselhos de Medicina como voz ativa no debate. 


\section{Exemplo (9)}

"O assunto foi analisado pelos conselheiros Roberto Luiz d'Ávila, presidente do Conselho Federal de Medicina (CFM); Carlos Vital Tavares Corrêa Lima, $1^{\circ}$ vicepresidente; e Mauro Britto, conselheiro federal pelo Mato Grosso do Sul e representante do Conselho na Comissão Nacional de Residência Médica". (Nomeação)

Em todo o texto introdutório, o autor trabalha a noção da 'intertextualidade manifesta' por meio do metadiscurso. Ele se distancia do discurso que está sendo representado, assim como do discurso que está sendo combatido, utilizando 'nomeações' e distinguindo níveis diferentes dentro do seu próprio texto. "O metadiscurso implica que o/a falante esteja situado/a acima ou fora de seu próprio discurso e esteja numa posição de controlá-lo ou manipulá-lo" (Fairclough, 2001, p.157). Como veremos nos exemplos 3 e 4, o autor se refere ao discurso representado sempre como 'o discurso do outro'.

\section{Exemplo (10)}

"O assunto foi analisado pelos conselheiros Roberto Luiz d'Ávila, presidente do Conselho Federal de Medicina (CFM); Carlos Vital Tavares Corrêa Lima, $1^{\circ}$ vicepresidente; e Mauro Britto, conselheiro federal pelo Mato Grosso do Sul e representante do Conselho na Comissão Nacional de Residência Médica. $O$ texto aponta a necessidade "de uma ação responsável do Estado para resgatar a qualidade do ensino médico e da assistência na rede pública". (Intertextualidade e nomeação)

Por fim, antes de iniciar o artigo ao qual o CFM se refere nesta introdução, os autores fazem outra pressuposição. Responsabilizam o Programa Mais Médicos, após completado um ano, pelas deficiências da saúde no Brasil, além de sugerir que o programa coloca em risco a saúde dos/as brasileiros/as. De forma categórica, o CFM ainda desqualifica os/as médicos/as estrangeiros/as na intenção de fortalecer seu argumento, chamando-os de intercambistas e, veladamente, de incompetentes. Aqui, a estratégia de construção simbólica utilizada foi o expurgo do outro, que representa o modo de operação da ideologia denominado Fragmentação, como visto em exemplos anteriores.

\section{Exemplo (11)}

“O artigo remete à série de preocupações sobre o futuro da saúde no Brasil, após um ano de criação do programa Mais Médicos. A análise chama a atenção para a necessidade de avalição da competência dos intercambistas estrangeiros, por estar em jogo a segurança de milhares de pacientes". (Fragmentação) 
Neste exemplo há um ponto controverso. Requerer a avaliação apenas dos/as médicos/as estrangeiros/as é, no mínimo, desconfiar de suas competências. Ademais, os/as médicos/as brasileiros do Programa Mais Médicos também não deveriam ser avaliados? Quando o artigo fala da necessidade de avaliar a competência dos/as intercambistas, ele desqualifica os/as profissionais da saúde ao chamá-los de intercambistas, assim como pressupõe a incompetência deles/as. Essa estratégia discursiva busca construir uma imagem ruim dos/as médicos/as estrangeiros/as. 


\title{
4.4 - TEXTO 4 - APM REPUDIA IMPROVISOS APRESENTADOS PELO GOVERNO FEDERAL COMO REMÉDIO PARA O SUS (Associação Paulista de Medicina, publicado em 11/07/2013)
}

\author{
Figura 4 - Texto 4 - APM repudia improvisos apresentados pelo Governo Federal como \\ remédio para o SUS
}

Sex, 12 de Julho de 2013 14:44

Na tentativa de tentar recuperar popularidade e apresentar uma resposta ao clamor das pessoas que foram recentemente às ruas, que, entre outras coisas, exigem melhor qualidade no atendimento do Sistema Unico de Saúde (SUS), o Governo Federal apresentou um programa chamado "Mais Médicos", que tende a não solucionar o problema do atendimento do SUS, nem a curto nem a longo prazo, porque não enfoca a principal questão, que é o financiamento insuficiente.

Além disso, o Programa desestrutura a grade curricular do curso de Medicina e não valoriza os profissionais de saúde. Analisando o projeto, apontamos os seguintes pontos sobre os quais temos divergências:

1. O mais grave é que os alunos de Medicina que atenderão no SUS ainda não serão médicos formados e, supervisionados apenas à distância, podem colocar a população em risco. Os pacientes do SUS não são de uma categoria inferior e não é justo que sejam tratados por alunos.

2. É inaceitável que o Governo Federal modifique de maneira intempestiva a grade curricular dos cursos de Medicina sem ouvir todos os setores envolvidos, em especial a comunidade acadêmica e os Conselhos de Medicina, que há muito vêm discutindo o aperfeiçoamento dos cursos.

3. As escolas médicas terão que buscar profundas mudanças para se adequar às novas exigências, passando por uma total reestruturação e novos custos, sem que isto represente novos conhecimentos técnicos e científicos para os alunos.

4. O aprendizado dos alunos de Medicina sempre se dá nos hospitais do SUS durante os dois anos de internato, portanto estes novos dois anos não vão acrescentar novos conhecimentos sobre o sistema.

5. Os graduados em Medicina por este novo sistema também sofrerão um grande transtorno, só entrando na vida profissional com cerca de 30 anos de idade.

6. Não é justo que os alunos de escolas públicas tenham que obrigatoriamente trabalhar para o SUS, mesmo que recebendo bolsaauxílio, para supostamente retribuir a gratuidade, uma vez que as escolas são mantidas por meio dos impostos pagos por toda sociedade, e que os médicos continuam pagando depois de formados. Para os alunos de escolas particulares, então, que também arcam com altas mensalidades, a medida é ainda mais descabida.

7. O programa é inadmissivel também por atrasar a formação de especialistas que o Brasil tanto necessita, como pediatras, ginecologistas e médicos de família, entre outros.

8. Outro argumento inaceitável é que estes novos dois anos de suposto treinamento possam ser abatidos da residência médica, uma vez que os programas são cuidadosamente preparados para formar especialistas.

O eventual resultado do Programa Mais Médicos só vai surgir no final de 2021, portanto um longo tempo para uma solução que precisa ser imediata, e cujo principal item a ser contemplado é uma mudança urgente na estrutura de financiamento da saúde.

Diz o Governo Federal ter se inspirado na Inglaterra para conceber o Programa Mais Médicos. O paradoxo é que a Inglaterra possui um sistema de saúde exclusivo e investe $10 \%$ de seu Produto Interno Bruto nele. No Brasil, são investidos apenas 3,5\% do PIB.

A vinda de médicos estrangeiros sem revalidar o diploma para comprovar se estão ou não qualificados é outra medida inaceitável. Para ter ideia do risco a que a população será exposta se a revalidação de diplomas for dispensada, no ano passado, o exame registrou alto índice de reprovação, em torno de $90 \%$.

Da mesma maneira, a abertura de mais vagas em escolas médicas sem qualidade não resolve o problema da suposta falta de médicos no Brasil, pelo contrário, pode gerar médicos com má qualificação. Abrir novas vagas requer infraestrutura de docentes, que o país comprovadamente não tem, e disponibilidade de hospitais com vocação universitária. Além do mais, a projeção é que, em 2021, o número de médicos formados no país esteja acima do que o Governo Federal preconiza como necessário para a população

Os médicos não aceitam serem responsabilizados pela ineficiência do SUS e têm a clareza de que não se consegue exercer a profissão sem uma infraestrutura adequada, portanto, se o Governo Federal não mirar cuidadosamente neste item, o Sistema Único de Saúde continuará não atendendo adequadamente a população.

Como solução para o problema da falta de profissionais de saúde em áreas remotas e nas periferias, pedimos especial empenho do Executivo para a aprovação da Proposta de Emenda Constitucional (PEC) 454/2009, que cria a carreira médica no serviço público, semelhante à de juízes e promotores. Aliada a um melhor financiamento, esta continua sendo a melhor alternativa para levar um serviço de qualidade à população.
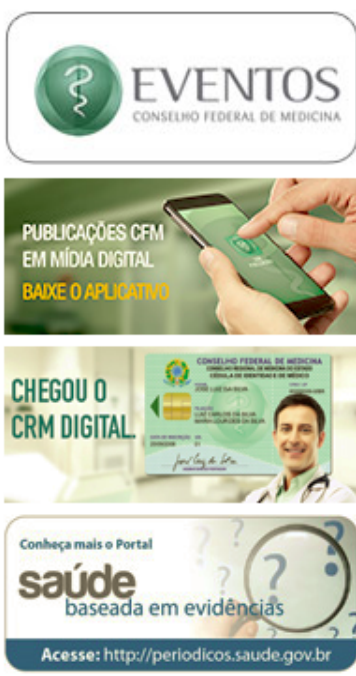

PROTOCOLOSE CARTILHAS
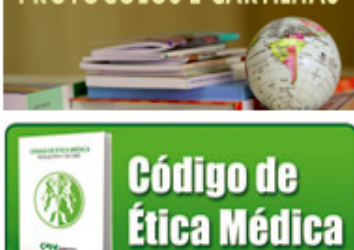

Eódigo de Elica Módica

Código de Processo

Ético Profissional

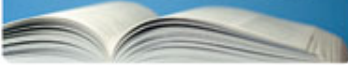

REGRAS DA

PUBLICIDADE MÉDICA

Conheça a Resoluchlo crom 1974/11
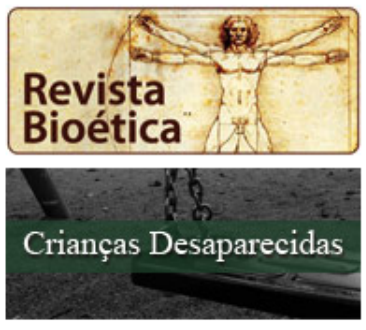

Enfrente

o Grack!

ANMAP 
Assim como no Texto 3, este também parte de uma 'pressuposição' já no início. Quando chama de "improviso" o Programa Mais Médicos, o autor suscita a falta de planejamento em sua implementação. Ademais, ele afirma que o programa não é um bom remédio para o SUS. De fato não é. Seu objetivo primeiro é satisfazer demandas de atendimento em lugares com déficit de profissionais.

No entanto, o Texto 4 trabalha com o pressuposto de que o programa já nasceu falido, afirmando categoricamente sua ineficiência. Além disso, sugere que o Programa Mais Médicos seria uma estratégia para reconquistar a popularidade do Governo. $\mathrm{O}$ fato é que as manifestações de julho de 2013 não foram em combate ao Governo Federal, e sim, contra a corrupção generalizada dos governos em todas as esferas. Logo, não cabe o argumento de que o programa seria para recuperar a popularidade, mesmo porque os problemas reclamados nas manifestações de junho de 2013 eram, em sua maioria, referentes a competências de governos locais ou regionais.

Conforme as definições dadas na seção 3.4.1.1 acerca da intertextualidade, destaco a particularidade que a pressuposição tem de fechamento das diferenças. Não se sabe quem é o/a autor/a do discurso, apenas o percebemos como uma representação de mundo já estabelecida, como se fosse um consenso. A pressuposição não é atribuída a vozes ou textos espcíficos. Portanto, se difere da intertextualidade realizada pelo disurso direto ou indireto, que fazem referência clara aos textos e vozes representados. Vejamos nos exemplos seguintes as diferenças.

\section{Exemplo (12)}

"Na tentativa de tentar recuperar popularidade e apresentar uma resposta ao clamor das pessoas que foram recentemente às ruas, que, entre outras coisas, exigem melhor qualidade no atendimento do Sistema Único de Saúde (SUS), o Governo Federal apresentou um programa chamado "Mais Médicos", que tende a não solucionar o problema do atendimento do SUS, nem a curto nem a longo prazo, porque não enfoca a principal questão, que é o financiamento insuficiente". (Pressuposição)

\section{Exemplo (13)}

"Diz o Governo Federal ter se inspirado na Inglaterra para conceber o Programa Mais Médicos. O paradoxo é que a Inglaterra possui um sistema de saúde exclusivo e investe $10 \%$ de seu Produto Interno Bruto nele. No Brasil, são investidos apenas 3,5\% do PIB". (Ironia) 
No Exemplo 12, o autor diz que o Programa Mais Médicos é uma tentativa de recuperar a popularidade do governo e responder ao clamor das pessoas que foram às ruas nas manifestações de junho de 2013. Essa pressuposição coloca como certa a avaliação feita no texto acerca do programa, porém não ativa nenhuma voz específica que assuma essa fala. Este é o ponto sobre qual Fairclough (2001) diz não ser fácil contrapor pressuposições. Elas são boas ferramentas de manipulação.

O Exemplo 13 utiliza da ironia quando declara que o Governo Federal se inspirou na Inglaterra para conceber o Programa Mais Médicos. A construção "Diz o Governo Federal ter se inspirado..." denota a falta de confiança nas ações do governo ao mesmo tempo em que coloca o Governo como principal representante do discurso. Esse exemplo deixa clara a abertura da diferença para as vozes ativadas no texto. 


\section{5 - TEXTO 5 - MANIFESTAÇÃO DO CRM-PR EM RESPOSTA AO PLANO "MAIS MÉDICOS", DO GOVERNO FEDERAL (Conselho Regional de Medicina do Paraná, publicado em 10/07/2013) \\ Figura 5 - Texto 5 - Manifestação do CRM-PR em resposta ao plano "Mais Médicos", do governo federal}

Qua, 10 de Julho de 2013 10:53

0 Conselho Regional de Medicina do Paraná vem a público reiterar seu repúdio à forma com que 0 governo federal tem tratado a saúde no Brasil. A ação midiática e eleitoreira criada na divulgação do plano "Mais Médicos" somente demonstra o descompasso do atual governo com as reais necessidades da população. Os ministros e a presidente perderam uma ótima oportunidade para declarar à nação um plano que efetivamente resgate 0 acesso $\mathrm{e}$ a qualidade da assistência à saúde.

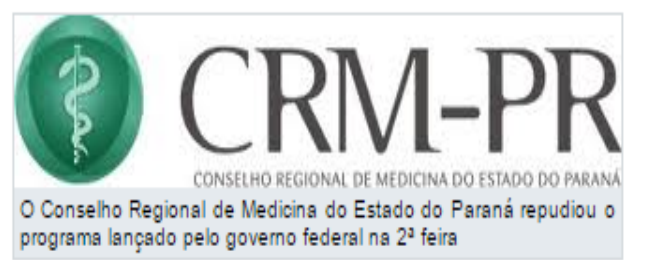

A sociedade brasileira merece mais respeito, especialmente os mais

vulneráveis e desassistidos. A superlotação das unidades de atendimento, a falta crônica de materiais, a falta de leitos hospitalares e de UTI demonstram claramente a ausência de planejamento em saúde, pois 0 crescimento populacional é muito maior que a adequação dos estabelecimentos.

Novamente não ouvimos do governo uma palavra quanto ao seu papel constitucional de garantir 0 aporte necessário de recursos financeiros para a equidade no SUS, pelo contrário, ouvimos programas que demonstram claramente que existe 0 interesse de manter um sistema precário para a população mais pobre, como se existissem cidadãos de diferentes categorias, baseado na exploração da mão de obra de estudantes e médicos.

Por fim, a vinda de profissionais formados no exterior sem a regularização do diploma, por meio da prova do REVALIDA, contraria qualquer senso de responsabilidade que se espera de um gestor público.

Os médicos paranaenses reafirmam seu compromisso na defesa dos direitos humanos e lutarão por todos os meios para garantilos.
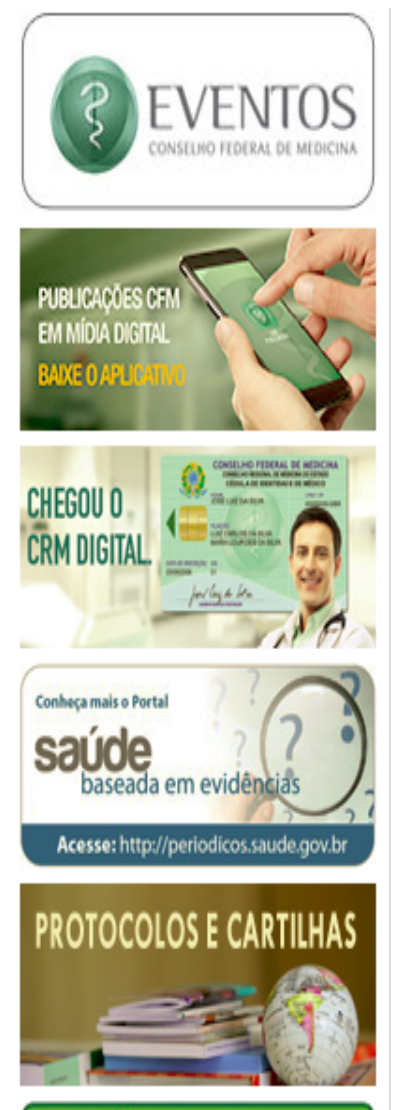

O título do Texto 5 contém um exemplo claro de intertextualidade. Percebemos o estabelecimento de um diálogo entre o Conselho Regional de Medicina do Paraná e o Governo Federal quando se fala em uma resposta de um para o outro. Conforme a concepção da cadeia de elos da comunicação elaborada por Bakhtin (1986), o texto em questão retoma outro texto anterior,de forma que deixa clara sua discordância de opinião.

No início do Texto 5 o autor também se remete a outro discurso anteriormente representado, quando diz que o CRM-PR reitera seu repúdio à forma como o Governo Federal tem tratado a saúde no Brasil, pois reiterar significa reafirmar um posicionamento anteriormente delimitado.

No próximo exemplo, onde notaremos as observações feitas nas linhas anteriores, fica clara também a presença de uma afirmação avaliativa que consiste em uma enunciação com a pretenção de defirnir algo como desejável ou indesejável. Quando o CRM-PR afirma o seu repúdio, ele está mostrando que é contra aquilo que avalia indesejável. 


\section{Exemplo (14)}

"O Conselho Regional de Medicina do Paraná vem a público reiterar seu repúdio à forma com que o governo federal tem tratado a saúde no Brasil. A ação midiática e eleitoreira criada na divulgação do plano "Mais Médicos" somente demonstra o descompasso do atual governo com as reais necessidades da população. Os ministros e a presidente perderam uma ótima oportunidade para declarar à nação um plano que efetivamente resgate o acesso e a qualidade da assistência à saúde". (Avaliação)

O Texto 5 ainda apresenta um exemplo de 'diferenciação' que tem por finalidade a discriminação em grupos diferentes de profissionais semelhantes, com o intuito de estabelecer o expurgo do outro. Enquanto os/as brasileiros/as são chamados/as de médicos/as, o autor do texto se refere aos/às médicos/as estrangeiros/as como "profissionais formados no exterior sem a regularização do diploma", como se percebe no exemplo seguinte.

\section{Exemplo (15)}

"Por fim, a vinda de profissionais formados no exterior sem a regularização do diploma, por meio da prova do REVALIDA, contraria qualquer senso de responsabilidade que se espera de um gestor público". (Diferenciação)

A afirmação do exemplo acima revela a pretensa superioridade dos/as médicos/as brasileiros/as, quando diz que a vinda de profissionais estrangeiros/as sem a revalidação do diploma contraria qualquer senso de responsabilidade. Nas entrelinhas, pode-se entender que a medicina dos países que enviaram médicos/as é de baixa qualidade e que colocaria em risco a vida dos/as brasileiros/as. Interessante notar que em nenhum momento o Portal Médico fala a respeito do REVALIDA para brasileiros/as, pois sabemos que existem vários profissionais formados aqui e com conhecimento insuficiente. Portanto, a exclusão desses atores é uma forma de representação que "apaga" suas responsabilidades enquanto condena a atuação dos/as estrangeiros/as. 


\section{6 - TEXTO 6 - CREMEgO, AMG E SIMEGO CRITICAM PROGRAMA MAIS MÉDICOS (Cremego, publicado em 09/07/2013)}

\section{Figura 6 - Texto 6 - Cremego, AMG e Simego criticam programa Mais Médicos \\ Cremego, AMG e Simego criticam programa Mais Médicos}

Ter, 09 de Julho de 2013 13:04

Em entrevista coletiva à imprensa, na manhã desta terça-feira (9), 0 presidente do Conselho Regional de Medicina do Estado de Goiás (Cremego), Salomão Rodrigues Filho, disse que o governo ouviu, mas não entendeu a voz das ruas e que a classe médica brasileira esta estarrecida com as trapalhadas da Medida Provisória que cria 0 programa Mais Médicos

O programa "Mais Médicos", anunciado pelo Governo Federal, apresenta medidas que não resolverão 0 caos instalado na saúde pública brasileira e se preocupa mais com a quantidade de médicos em atuação do que com a qualidade da assistência prestada à população. A opinião é do presidente do Cremego, Salomão Rodrigues Filho, para quem a presidente Dilma Rousseff ouviu, mas não compreendeu as ruas.

Em entrevista coletiva à imprensa, ele observou que a Medida Provisória que cria o programa Mais Médicos só pode dar errado, porque está cheia de trapalhadas que deixaram a classe médica estarrecida. Um exemplo são as mudanças no curso de medicina. "A presidente baixou medidas que afetam profundamente a formação dos médicos sem antes discutilas com as entidades médicas e com as universidades e, assim, ficou exposta a erros técnicos e políticos", diz Salomão Rodrigues.

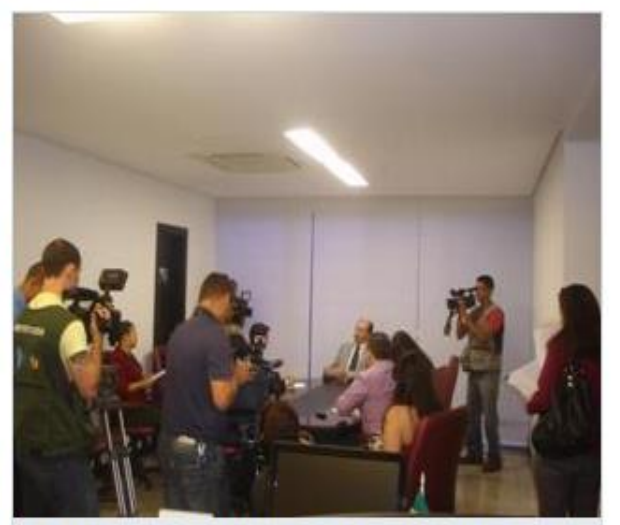

Ementrevista s imprense nesta $3^{2}$ feirs, 0 presidente do Cremego criticou o programa lançado pelo governo federal

O programa prevê que os alunos que ingressarem no curso de medicina a partir de 2015 terão não seis, mas oito anos de curso, sendo os dois últimos de trabalho obrigatório nas pequenas cidades para quais forem escalados. "Nestes dois anos serão estudantes ou serão médicos? Se forem estudantes precisarão ter ao seu lado professores, que não existem nas pequenas cidades. Se forem médicos, não terão eles o direito constitucional de escolher onde morar e trabalhar?", questiona o presidente do Cremego, que classificou os dois anos extras de curso propostos pelo governo, como "trabalho escravo"

Salomão Rodrigues cita que para Anis Kfouri Junior, conselheiro da $\mathrm{OAB}$, obrigar o estudante a trabalhar na área pública pode violar o livre exercicio profissional e a depender do texto da MP, esse estágio no SUS pode ser anticonstitucional.

0 presidente do Cremego também critica 0 anúncio de criação de novas vagas em cursos de medicina. 0 governo anunciou a meta de criar 11.447 novas vagas em cursos de medicina até 2017, mas, segundo ele, se esqueceu de que mais de metade das atuais escolas de medicina não dispõe de hospital escola o que deveria ser prioridade, pois sem ele é impossivel formar um bom médico.

"Não faltam médicos. Faltam condiçōes de trabalho", ressalta Salomão Rodrigues

O presidente do Cremego, Salomão Rodrigues Filho, ressalta que a premissa de que faltam médicos no Brasil está errada. $\mathrm{O}$ que faltam, segundo ele, são condições de trabalho para o médico e estrutura adequada para o exercício da medicina. Para ele, percebe-se que o governo quer quantidade e não qualidade, mas as medidas anunciadas não vão ter o condão de estimular 0 médico a se fixar no interior, pois a falta de condições de trabalho e a precariedade dos vínculos trabalhistas, comum em muitas cidades, afastam o profissional.

"Hoje, o médico não vai porque não tem condições de trabalho, não tem segurança trabalhista", diz, acrescentando que nas pequenas e médias cidades faltam hospitais, laboratórios, agências transfusionais de sangue e pessoal técnico para formar a equipe médica. Para Salomão Rodrigues, a solução para suprir a falta de médicos em regiỗes de déficit está na criação de uma carreira de Estado para o médico e na oferta de condições dignas de atendimento.

Ele observa que embora o governo tenha desistido da ideia absurda de trazer médicos cubanos com apenas 3 anos de curso de formação, a insistência em trazer médicos estrangeiros sem a revalidação de seus diplomas continua preocupando as entidades médicas, pois é vista como uma ameaça à população a ser assistida "Qualquer médico estrangeiro bem formado não encontra dificuldade para revalidar seu diploma no Brasil", afirma Salomão Rodrigues, que reforça que as entidades não são contra a vinda de médicos formados no exterior, desde que tenham seus diplomas revalidados

\section{Entidades vão discutir ações políticas, jurídicas e deflagração de uma greve geral}

Amanhã 10 o presidente do Cremego, Salomão Rodrigues Filho, participa da uma reunião das entidades médicas nacionais, em Brasília, para decidir quais medidas serão adotadas pelos médicos diante dos anúncios do governo. Em pauta: a deflagração de uma greve geral, ações judiciais e ações políticas junto ao Congresso Nacional e mobilizações nas ruas. Fiquem atentos aos informativos do Cremego, AMG e Simego com novas informações sobre o assunto. 
Assim como nos demais textos publicados pelo Portal Médico, ressalto algumas nomeações feitas no Texto 6. Essa estratégia discursiva utilizada para reforçar um argumento dedicando sua autoria a uma pessoa de prestígio, também demonstra a exclusão de vozes empreendida pelo veículo. Em raros momentos o Conselho Regional de Medicina de Goiás fala em nome da população ou dá voz ao povo, posicionando sempre o/a médico/a no polo interessado da questão. Isto mostra claramente a preocupação exclusiva com a classe médica, mesmo se tratando de um programa feito para o povo. Entre doze nomeações feitas no texto, nove foram referentes ao presidente do Conselho, duas à presidenta Dilma Roussef e uma a um conselheiro da $\mathrm{OAB}$ chamado Anis Kfouri Junior.

Portanto, é preciso que o leitor tenha em mente o propósito do Portal Médico, qual seja, a defesa dos interesses corporativos da classe médica. É natural que esse veículo "levante a bandeira" do Conselho Federal de Medicina, pois é responsável por assessorar e cuidar da imagem das instituições reguladoras da profissão.

Abaixo, alguns exemplos dessas nomeações.

\section{Exemplo (16)}

"Em entrevista coletiva à imprensa, na manhã desta terça-feira (9), o presidente do Conselho Regional de Medicina do Estado de Goiás (Cremego), Salomão Rodrigues Filho, disse..." (Nomeação)

"A opinião é do presidente do Cremego, Salomão Rodrigues Filho, para quem a presidente Dilma Rousseff ouviu, mas não compreendeu as ruas." (Nomeação)

"Salomão Rodrigues cita que para Anis Kfouri Junior, conselheiro da OAB, ..." (Nomeação)

"Não faltam médicos. Faltam condições de trabalho", ressalta Salomão Rodrigues." (Nomeação)

Além das nomeações, o Texto 6 trabalha com diversas pressuposições. Importante ressaltar que as pressuposições são conferidas a indivíduos de prestígio social por meio das nomeações. Entendidas como fatos ou dados consensuais, nada mais pertinente do que responsabilizar pelas pressuposições pessoas que possam a elas dar legitimidade. Entre outras pressuposições, veremos abaixo dois exemplos que esclarecem bem a utilização dessa categoria discursiva. 


\section{Exemplo (17)}

"Em entrevista coletiva à imprensa, na manhã desta terça-feira (9), o presidente do Conselho Regional de Medicina do Estado de Goiás (Cremego), Salomão Rodrigues Filho, disse que o governo ouviu, mas não entendeu a voz das ruas e que a classe médica brasileira está estarrecida com as trapalhadas da Medida Provisória que cria o programa Mais Médicos". (Pressuposição)

O texto em análise trabalha com o pressuposto de que o povo foi às ruas para pedir melhorias na saúde, enquanto evidências mostram que os motivos foram diversos. Como explanado no início desta dissertação, as revoltas populares foram iniciadas pelo inconformismo com o aumento das tarifas do transporte público em São Paulo. Embalado pela empolgação do protesto, o País se uniu para reivindicar direitos diversos, tendo como mote principal o fim da corrupção nos governos em todas as esferas.

Ademais, os maiores problemas de saúde pública no Brasil são de responsabilidade dos governos estaduais, o que revela mais um pressuposto no texto em questão: a ideia de que as falhas do sistema de saúde são reflexos de políticas públicas ineficientes do Governo Federal.

\section{Exemplo (18)}

"Em entrevista coletiva à imprensa, ele observou que a Medida Provisória que cria o programa Mais Médicos só pode dar errado, porque está cheia de trapalhadas que deixaram a classe médica estarrecida". (Pressuposição)

De acordo com a definição de avaliação, que diz respeito à maneira como os autores comprometem-se com o que é considerado desejável ou não, no Exemplo 3 podemos percebê-la de forma clara. $\mathrm{O}$ autor faz uma afirmação avaliativa quando atribui ao Programa Mais Médicos a qualidade de "trapalhada", afirmando que só pode dar errado.

Os textos seguintes foram extraídos do site Pragmatismo Político. Assim como os textos do Portal Médico, esse material tem produções variadas entre veículos de comunicação da grande mídia brasileira ou autores que escrevem periodicamente para o site. Como veremos, o Texto 7 é de autoria de Mauro Donato (DCM). O Texto 8 é do próprio Pragmatismo Político. O Texto 9 foi publicado pela Agência Brasil 247. O Texto 10 foi escrito por Ricardo Palácios, médico brasileiro formado no exterior. Já o Texto 11, foi produzido por Renato Rovai, em seu blog. E, por fim, o Texto 12 é mais um de autoria do Pragmatismo Político. 
4.7 - TEXTO 7 - MAIS MÉDICOS, URGENTE! (Por Mauro Donato, DCM, publicado em 22/07/2014)

Figura 7 - Texto 7 - Mais Médicos, urgente!

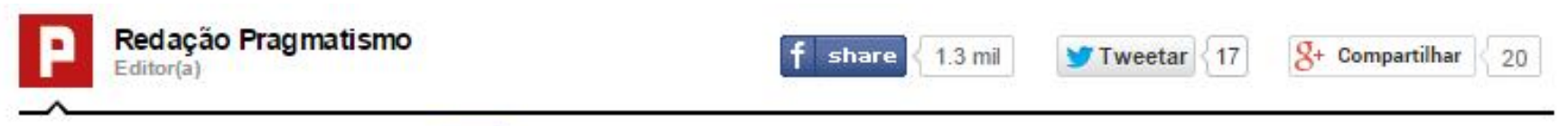

SAÚDE Ш 22/JUL/2014 ȦS 12:45 34 COMENTÁRIOS

\section{Mais Médicos, urgente!}

Homem morre após ter atendimento negado em porta de hospital. Dois profissionais de saúde, um com as mãos no bolso, observaram a vítima agonizar e pedir ajuda e nada fizeram

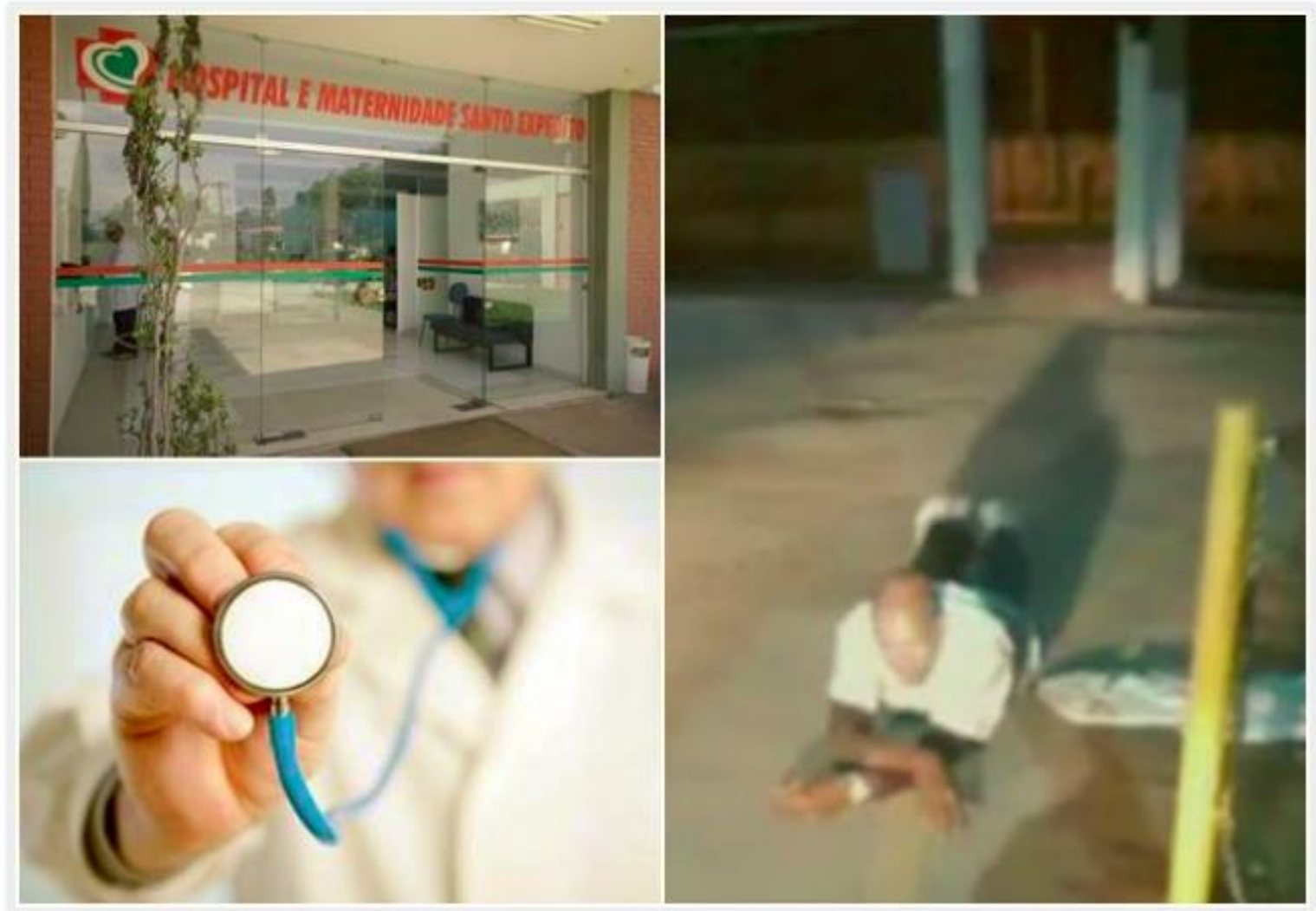

Segurança Nelson França morreu depois de pedir socorro e agonizar na porta do Hospital Santo Expedito (Pragmatismo Politico)

Dois enfermeiros, um com as mãos no bolso, observam o segurança Nelson França agonizar. Estão em frente ao hospital onde trabalham. O Hospital e Maternidade Santo Expedito, em Itaquera, atende apenas clientela particular e convênios. 
Os enfermeiros não agem, não socorrem. Nelson França irá morrer poucos minutos depois.

Dentro de uma viatura de resgate, a caminho de um hospital público, segundo relato dos bombeiros, ou ali mesmo no local segundo a testemunha Daniela Gomes que, além de gravar em vídeo a inoperância dos funcionários, diz ter ouvido um médico tirar a pulsação da vítima e afirmar que já se encontrava em óbito ali na calçada.

Talvez a disposição da dupla fosse a de prestar socorro, mas sua paralisia indica que algo além de sua alçada a impedia. Seria a direção do hospital? Um terceiro enfermeiro, Leonardo B. Santos, se aproximou e ordenou que a dupla retornasse ao trabalho e abandonasse Nelson França ali.

\section{A nota oficial diz:}

A direção do Hospital Santo Expedito determinou abertura de sindicância para apuração do ocorrido e, caso seja apurada a responsabilidade de algum profissional, a diretoria do hospital não hesitará em punir com rigor os eventuais envolvidos, colocando-se à disposição das autoridades policiais e do respectivo Conselho de Enfermagem.

O Hospital Santo Expedito não corrobora de forma alguma com qualquer tipo de omissão de seus profissionais, visto que, em sua trajetória, nunca furtou-se em atender vítimas de acidente de trânsito, pessoas baleadas, pessoas em processo de infarto agudo do miocárdio e com acidente vascular cerebral (AVC), entre outras ocorrências, mesmo que desprovidas de convênio de assistência médica.

A diretoria do Hospital Santo Expedito sempre priorizou o atendimento à comunidade local, composta na sua grande maioria por pessoas menos favorecidas. Nesse caso, em particular, o senhor Nelson França foi irresponsavelmente abandonado pelo condutor da lotação que, caso tivesse adentrado ao pronto-socorro, distante 150 metros do local, este fato não teria acontecido.

O Hospital Santo Expedito está totalmente à disposição para eventuais esclarecimentos.

Atenciosamente,

Direção Hospital Santo Expedito

A nota deixa claro que irá responsabilizar os enfermeiros e médicos envolvidos (um comportamento semelhante ao da polícia militar que condena os que são pegos em flagrante ao atuarem de acordo com as diretrizes implícitas) e também o motorista da lotação, a distância entre a porta do hospital e o despejo da vítima... Santo expedito? De expedito não tem nada. Nelson França agonizou no chão por uma hora.

Há pouco mais de um mês, o fotógrafo Luiz Claudio Marigo, 63, morreu de forma semelhante no Rio de Janeiro. Marigo passou mal dentro de um ônibus, foi levado ao Instituto Nacional de Cardiologia e, adivinhem, não foi socorrido. 
O que faz profissionais da saúde comportarem-se dessa maneira? O programa Mais Médicos é, desde sua criação, alvo de críticas virulentas acerca de sua intenção eleitoreira, de sua composição política, sua forma de pagamento, disso, daquilo. Alguém já parou para pensar que a necessidade de "mais médicos" é também na acepção do termo e não apenas em número de profissionais?

O que falta, são profissionais imbuídos da motivação primeira dessa área: salvar vidas. Assistir seres humanos. Estejam onde estiverem. E com ou sem dinheiro no bolso.

No entanto, o que vemos são instituiç̧̃es e médicos mercenários. A profissão ganhou fama de rentabilidade sabe-se lá em que ponto da história e hoje vemos a mercantilização da saúde através das grandes empresas de convênios, bairros nobres pinhados de consultórios e clínicas particulares mas nenhuma disposição para atuação na periferia.

É por esses e outros motivos que a ampliação do programa do governo federal se faz necessária. Seja com cubanos ou tibetanos, precisamos de mais médicos e mais amor, por favor. E rápido.

\section{Mauro Donato, DCM}

O Texto 7 exemplifica o discurso contra-hegemônico de combate ao discurso anterior sustentado pelo Portal Médico. Ele questiona a comercialização da saúde e a falta de responsabilidade profissional de quem vende essa "mercadoria". Coloca em discussão o posicionamento "mercenário" de quem deveria estar preocupado em salvar vidas.

Baseado em relações interdiscursivas ele desconstrói e reconstrói a identidade dos/as médicos/as brasileiros/as utilizando de ironia na representação de atores sociais. Respaldado por avaliações e pela legitimação por racionalização, o autor "implora" mais atenção e amor à profissão de médico/a. O exemplo seguinte demonstra a utilização da ironia ao mesmo tempo em que faz menção a um texto de ordem superior que possa ter impedido a atuação dos/as profissionais que presenciaram a morte do cidadão.

\section{Exemplo (19)}

"Talvez a disposição da dupla fosse a de prestar socorro, mas sua paralisia indica que algo além de sua alçada a impedia. Seria a direção do hospital? Um terceiro enfermeiro, Leonardo B. Santos, se aproximou e ordenou que a dupla retornasse ao trabalho e abandonasse Nelson França ali”. (Ironia)

A ironia se faz presente no momento em que o autor utiliza o termo 'paralisia', que também pode ser compreendido como um termo médico utilizado para uma enfermidade. Ademais, quando o autor fala que "talvez a disposição da dupla fosse a de 
prestar socorro" ele também está sendo irônico, pois qualquer profissional da saúde deve estar prontamente disposto a prestar socorro.

Outra categoria de análise que podemos perceber no Texto 7 é a interdiscursividade ou intertextualidade constitutiva. Como podemos perceber no exemplo seguinte, o autor do texto faz menção a um discurso que já foi proferido anteriormente, quando fala que o programa é alvo de críticas virulentas.

\section{Exemplo (20)}

"O que faz profissionais da saúde comportarem-se dessa maneira? O programa Mais Médicos é, desde sua criação, alvo de críticas virulentas acerca de sua intenção eleitoreira, de sua composição política, sua forma de pagamento, disso, daquilo. Alguém já parou para pensar que a necessidade de "mais médicos" é também na acepção do termo e não apenas em número de profissionais?" (Interdiscursividade)

Além disso, a foto presente na notícia tem um significado muito forte. Por meio de uma montagem, o produtor da imagem tentou dar sentido aos fatos com uma mensagem visual. Ele justapôs a fachada do hospital, um médico e o paciente que viria a falecer. Com isso a mensagem passada é a seguinte: "Paciente morre ao lado de hospital enquanto profissional da saúde assiste sem fazer nada". A foto é o resumo do Texto 7. Essa construção ilustra a capacidade de outras semioses emitirem sentidos além do texto escrito. 
4.8 - TEXTO 8 - GLOBO É OBRIGADA A RECONHECER A QUALIDADE DOS MÉDICOS CUBANOS (Pragmatismo Político, publicado em 11/06/2014)

Figura 8 - Texto 8 - Globo é obrigada a reconhecer a qualidade dos médicos cubanos

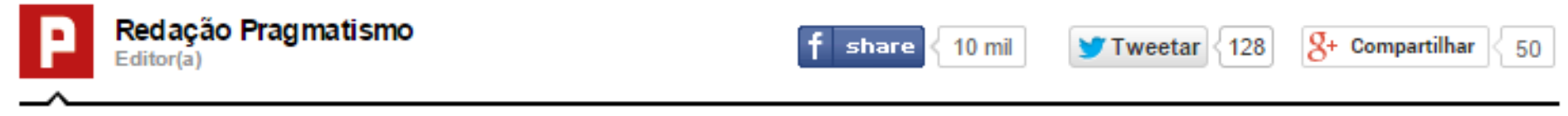

SAÚdE [11/JUN2014 ÀS 10:36 64 COMENTÁRIOS

\section{Globo é obrigada a reconhecer qualidade dos médicos cubanos}

O dia em que um jornalista da Rede Globo falou a verdade sobre os médicos cubanos - na própria emissora - e todos foram obrigados a ouvir

O jornalista Jorge Pontual, no programa Em Pauta, da GloboNews, foi chamado a falar, no telão, sobre os médicos cubanos no Brasil. Ao lado dele, na grande tela, estava a também comentarista Eliane Cantanhêde, que em sua coluna no jornal Folha de S. Paulo chegou a dizer que os médicos cubanos chegariam ao Brasil em "aviões negreiros!

\section{Veja também: Médicas patricinhas envergonham o Brasil}

Ele iniciou dizendo que havia entrevistado a pesquisadora americana Julia Silver para o programa que comanda, também na Globo News, o Sem Fronteiras. A partir desta entrevista, Pontual disse o seguinte (transcrição do vídeo abaixo):

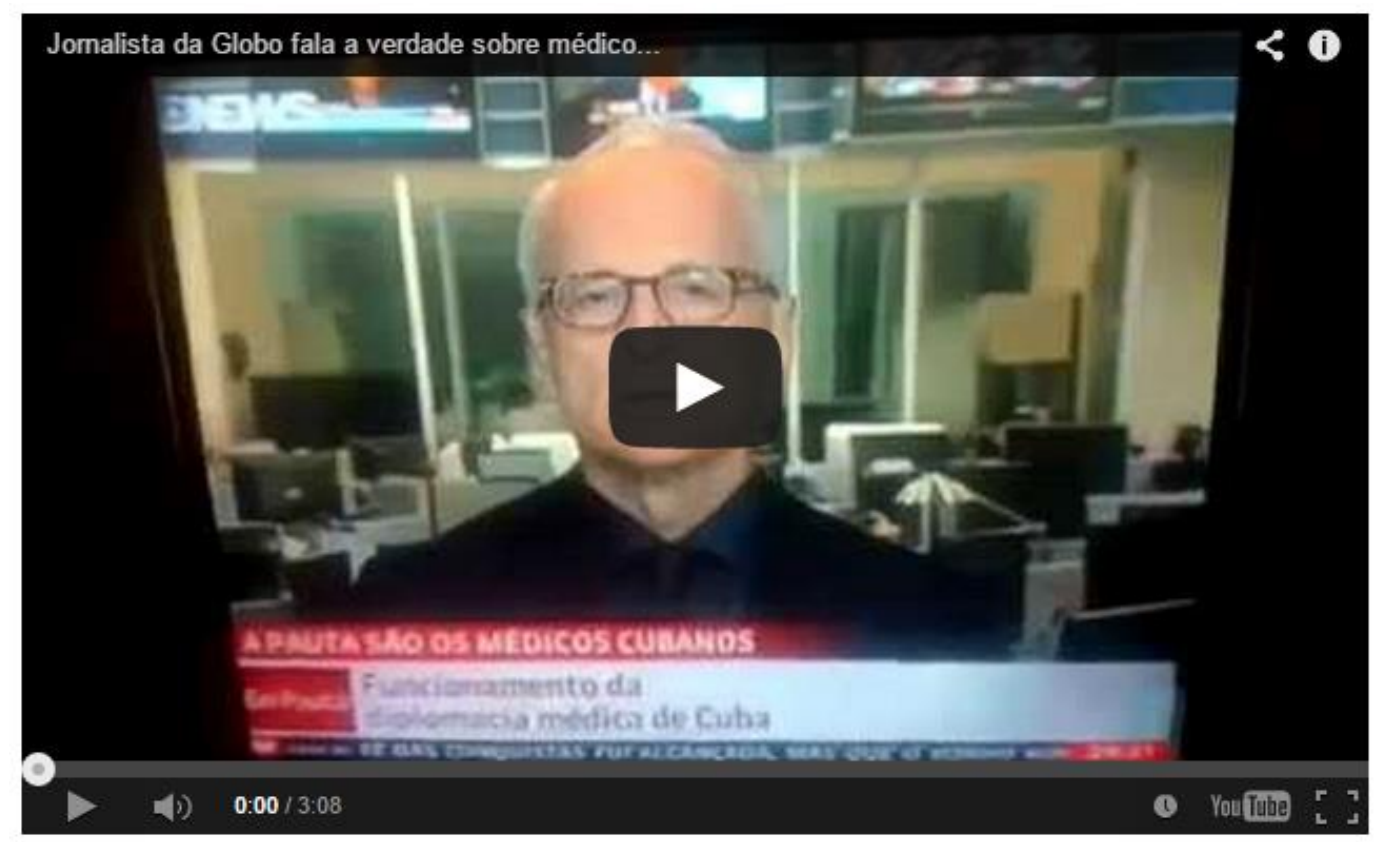


- Que, após a revolução de 1959, metade dos médicos de Cuba fugiram do país;

- Sobraram apenas 3 mil e 14 professores de Medicina;

- Diante da iminência do ensino de Medicina acabar em Cuba, o revolucionário Ernesto Che Guevara, que era médico, criou e implantou o sistema de saúde comunitária;

- Graças a esse sistema, milhares de novos médicos cubanos voltaram a se formar e puderam, mais tarde, sair pelo mundo em missões humanitárias;

- Num desses momentos, salvaram 600 mil africanos da cegueira;

- Noutro, fizeram um trabalho excepcional após o terremoto do Haiti;

- Atuaram no sentido de fazer, hoje, com que Cuba tenha índices de saúde melhores do que países como os Estados Unidos e muitos da Europa;

- Levaram a Organização Mundial de Saúde a considerar o sistema cubano um modelo a ser seguido por todos os paises do mundo;

- A resistência das entidades médicas, explicou Pontual, se deu, em outros países, antes do que está acontecendo no Brasil, porque o sistema cubano é uma verdadeira revolução, com o médico vivendo dentro das comunidades;

- Finalizou Pontual, cravando: "A Medicina de Cuba é um exemplo para o mundo"

(O programa exibido no vídeo data de agosto de 2013. Na época, a GloboNews censurou a fala de Jorge Pontual na matéria que foi publicada em seu site. O Programa Mais Médicos enfrenta, até hoje, oposição dos grandes veículos de comunicação e do Conselho Federal de Medicina do Brasil)

O Texto 8 é uma obeservação do Pragmatismo Político acerca de um comentário sobre o Programa Mais Médicos feito por um jornalista da Rede Globo. O título do texto apresenta uma pressuposição, quando diz que a "Globo é obrigada a reconhecer a qualidade dos médicos cubanos". Neste enunciado considera-se que, de fato, os médicos cubanos são qualificados e, por isso, há a obrigação de reconhecêlos. O subtítulo da matéria reforça o argumento acima apresentado, pois afirma que o jornalista diz a verdade sobre os médicos cubanos. Vejamos o exemplo seguinte. 
Exemplo (21)

“GLOBO É OBRIGADA A RECONHECER QUALIDADE DOS MÉDICOS CUBANOS

O dia em que um jornalista da Rede Globo falou a verdade sobre os médicos cubanos - na própria emissora - e todos foram obrigados a ouvir"

Em seguida, o texto faz duas nomeações, primeiro ressaltando quem foi o jornalista responsável pelo comentário e, depois, destacando em quem ele se baseou para dar opiniões sobre o Programa Mais Médicos, como podemos perceber nos exemplos abaixo.

\section{Exemplo (22)}

"O jornalista Jorge Pontual, no programa Em Pauta, da GloboNews, foi chamado a falar, no telão, sobre os médicos cubanos no Brasil”. (Nomeação)

\section{Exemplo (23)}

"Ele iniciou dizendo que havia entrevistado a pesquisadora americana Julia Silver para o programa que comanda, também na Globo News, o Sem Fronteiras". (Nomeação)

O Texto 8 se encerra com o modo de operação da ideologia chamado legitimação. Mais especificamente, neste caso, a legitimação é construída por meio da racionalização, a partir da enumeração de fatos e dados que sustentam a importância e qualidade do atendimento médico cubano. O jornalista da Rede Globo lista 10 motivos pelos quais os/as médicos/as cubanos/as devem receber o reconhecimento dos/as médicos/as brasileiros/as. 
4.9 - TEXTO 9 - MÉdica CUBANA CONCLUI SEU PLANO E CONSEGUE ASILO NOS EUA (Brasil 247, publicado em 03/04/2014)

Figura 9 - Texto 9 - Médica cubana conclui seu plano e consegue asilo nos EUA

SAÚDE ["] 03/APR/2014 ÀS 14:15 12 COMENTÁRIOS

\section{Médica cubana conclui seu plano e consegue asilo nos EUA}

Depois de abandonar o Mais Médicos, pedir socorro ao DEM e conseguir um emprego na Associação Médica Brasileira, a cubana Ramona Rodríguez finalmente tem o que queria: resposta positiva dos EUA ao seu pedido de asilo político. Ela já desembarcou em Miami, na Flórida

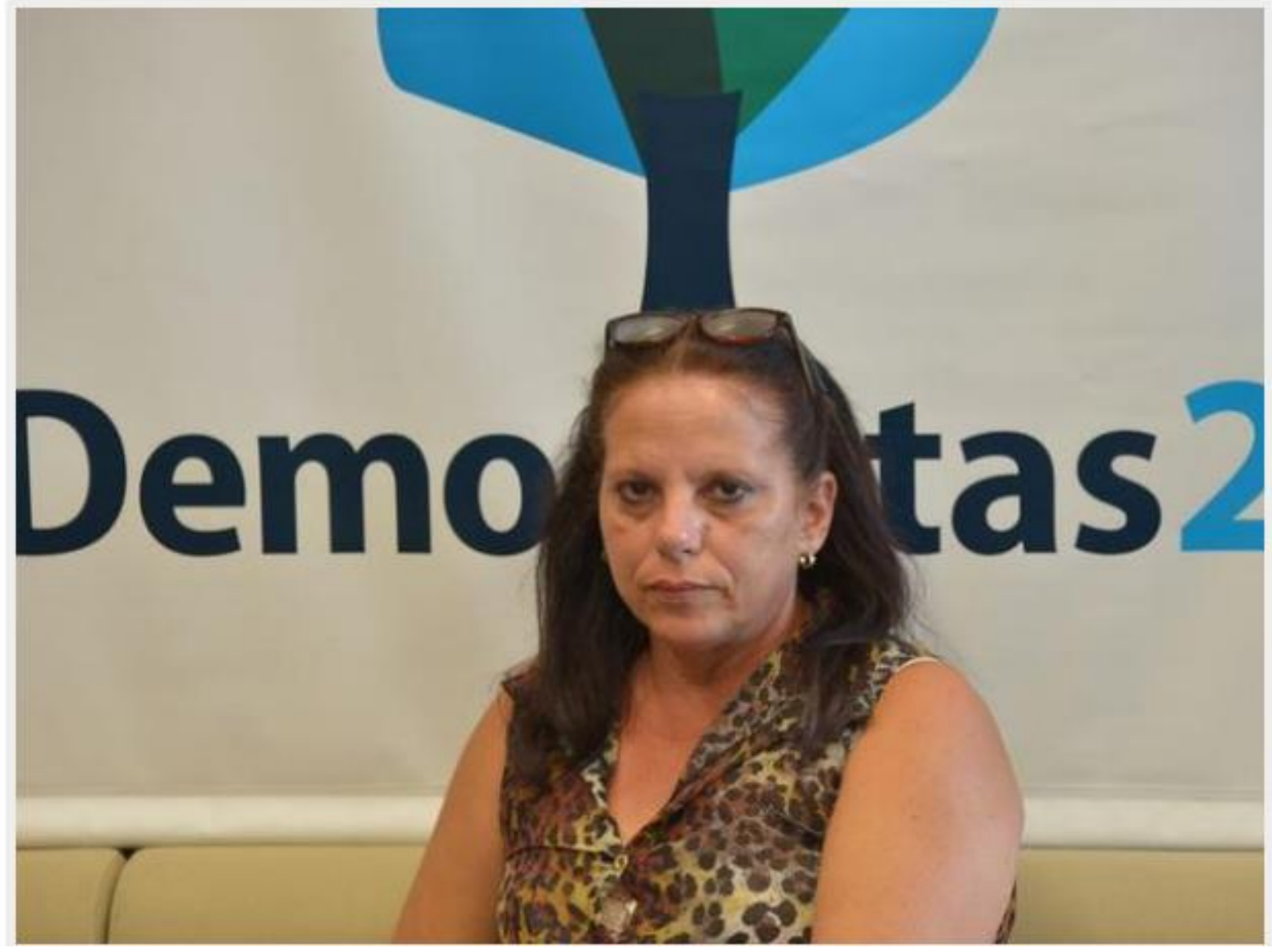


A médica cubana Ramona Rodríguez, que abandonou o programa Mais Médicos, pelo qual atuava no Pará, foi socorrida pela liderança do DEM, partido com o qual conseguiu até hospedagem em Brasília, e conseguiu um emprego na Associação Médica Brasileira, que pediu asilo político por ela ao governo brasileiro, finalmente concluiu seu plano esta semana e desembarcou em Miami, na Flórida, Estados Unidos.

\section{Leia também: PSDB e DEM preferem tirar médicos do Brasil e levá-los a Miami}

Segundo a AMB, ela comunicou seu pedido de demissão no domingo 30 e embarcou para os Estados Unidos, onde chegou nesta segunda-feira 31 pela manhã. Segundo a entidade, "a partida para os Estados Unidos (que foi feita de forma independente pela própria médica) motivou-se pelo apoio do governo americano a profissionais da saúde cubanos em situação de instabilidade com o regime político da ilha".

"Respeitamos a decisão pessoal da doutora Ramona. Enquanto ela esteve conosco, procuramos mostrar que os médicos brasileiros nada têm contra os médicos estrangeiros. Nosso posicionamento em relação ao Programa Mais Médicos está relacionado com a forma que médicos cubanos são contratados e vivem no país, com uma situação de trabalho que é análoga à escravidão", disse o presidente da AMB, Florentino Cardoso.

Ramona causou polêmica ao deixar o Mais Médicos no início de fevereiro. Na época, já havia sido divulgada sua intenção de ir para os Estados Unidos, onde tinha um namorado. O fato foi negado por ela e pelo DEM. Agora, porém, a história se concluir e fica no ar se ela tinha, desde quando saiu de Cuba para trabalhar no Brasil, a intenção de desembarcar em Miami.

Em balanço do programa divulgado nesta terça-feira $1^{\circ}$, a presidente Dilma Rousseff anunciou que, em abril, mais 3.745 profissionais vão se integrar ao Mais Médicos e começar a atender a população, atingindo $100 \%$ dos pedidos feitos pelos municípios quando o programa foi lançado. O Mais Médicos conta hoje com profissionais atuando em mais de $70 \%$ do total de municípios do país -9.490 médicos em 3.025 municípios e 31 distritos indígenas.

"Até agora, milhões de pessoas já foram atendidas pelos médicos do programa, formados no Brasil ou no exterior. Na última semana, foi divulgada uma pesquisa feita com os brasileiros atendidos pelos médicos formados no exterior e o resultado nos dá a certeza de que estamos no caminho certo. Porque quase $70 \%$ consideram o atendimento ótimo ou bom. Duas em cada três aprovam a decisão de trazer médicos formados fora do Brasil para melhorar o atendimento nos nossos postos de saúde. A aprovação é ainda maior na região Nordeste, onde $72 \%$ das pessoas concordam com a decisão", disse a presidente, em sua coluna semanal Conversa com a Presidenta.

\section{Brasil 247}

O Texto 9 é o único exemplo do corpus principal que representa expressamente um profissional de Cuba atuante no Programa Mais Médicos. Ainda que esteja falando de uma médica desertora do programa, sua representação é feita por meio de nomeações 
que incluem seu nome próprio e seu título profissional. Ao contrário das realizações do Portal Médico, este texto publicado pelo Pragmatismo Político se refere à cubana como médica e doutora em diferentes partes do texto, mesmo que esteja depreciando sua atitude.

\section{Exemplo (24)}

"A médica cubana Ramona Rodríguez, que abandonou o programa Mais Médicos, ..." (Nomeação)

\section{Exemplo (25)}

“Respeitamos a decisão pessoal da doutora Ramona". (Nomeação)

No Texto 9 também conferimos a intertextualidade constitutiva, ou interdiscursividade, nas palavras de Fairclough (2001). Dois discursos mantidos pela classe médica são representados na notícia: o discurso que faz analogia entre o trabalho dos/as cubanos/as no Programa Mais Médicos e o trabalho escravo, e o discurso mais recorrente, que desqualifica os/as profissionais cubanos/as enquanto exalta os/as brasileiros/as, como podemos ver no exemplo seguinte.

\section{Exemplo (26)}

"Respeitamos a decisão pessoal da doutora Ramona. Enquanto ela esteve conosco, procuramos mostrar que os médicos brasileiros nada têm contra os médicos estrangeiros. Nosso posicionamento em relação ao Programa Mais Médicos está relacionado com a forma que médicos cubanos são contratados e vivem no país, com uma situação de trabalho que é análoga à escravidão", disse o presidente da AMB, Florentino Cardoso. (Intertextualidade)

No trecho acima, podemos notar claramente a mudança discursiva passado quase um ano do incício do programa. Quando o presidente da AMB diz que os/as médicos/as brasileiros/as não têm nada contra os/as médicos/as cubanos/as ele retoma e contraria o discurso que o Portal Médico deixou claro em quase todos seus textos: os/as médicos/as cubanos/as seriam desqualificados/as e, portanto, colocariam a saúde da população em risco. Logo, o discurso que antes era de repulsa aos médicos/as cubanos/as se transferiu para a forma de contratação e situação de trabalho.

O Texto 9 se encerra com uma estratégia de legitimação do Programa Mais Médicos por racionalização. $\mathrm{O}$ autor faz referência a pesquisas e ao discurso da presidenta para fortalecer a importância do programa. Fazendo uso da assimilação, o texto apresenta 
dados estatísticos e a representação do povo como um grupo homogêneo de pessoas a favor do programa, como veremos no exemplo seguinte.

\section{Exemplo (27)}

"Até agora, milhões de pessoas já foram atendidas pelos médicos do programa, formados no Brasil ou no exterior. Na última semana, foi divulgada uma pesquisa feita com os brasileiros atendidos pelos médicos formados no exterior e o resultado nos dá a certeza de que estamos no caminho certo. Porque quase $70 \%$ consideram o atendimento ótimo ou bom. Duas em cada três aprovam a decisão de trazer médicos formados fora do Brasil para melhorar o atendimento nos nossos postos de saúde. A aprovação é ainda maior na região Nordeste, onde $72 \%$ das pessoas concordam com a decisão", disse a presidente, em sua coluna semanal Conversa com a Presidenta. (Racionalização) 
4.10 - TEXTO 10 - OS MÉDICOS BRASILEIROS TÊM MEDO DE QUÊ? (Por Ricardo Palácios, publicado em 09/07/2013)

Figura 10 - Texto 10 - Os médicos brasileiros têm medo de quê?

Luis Soares

Colunista

SAÚdE [Ш 09/JUL/2013 ÀS 20:53 18 COMENTÁRIOS

\section{Os médicos brasileiros têm medo de quê?}

\section{Médico colombiano e com diploma devidamente revalidado no Brasil escreve sobre a postura reativa da categoria à vinda de profissionais cubanos}

\section{Por Ricardo Palascios*}

A exploração por parte do capital é uma novidade para o grêmio médico no Brasil. Recentemente um dos setores mais conservadores da sociedade viu sua condição de profissão liberal ser extinta pelos operadores dos planos de saúde que exploram a mais-valia obtida através da prestação dos serviços. Assim, aqueles que foram selecionados através de provas excludentes nas escolas de medicina e que sonham algum dia virar burgueses estão hoje na rua para lutar por reivindicações trabalhistas. Sim, os médicos agora fazem parte da classe trabalhadora, mesmo que não tenham consciência dessa nova relação com os meios sociais da produção.

No site dos Conselhos Regionais e do Conselho Federal de Medicina aparecem destacados apelos mais apropriados para sindicatos que para órgãos fiscalizadores de uma profissão, hipertrofiando sua função secundária de zelar "pela valorização do profissional médico".

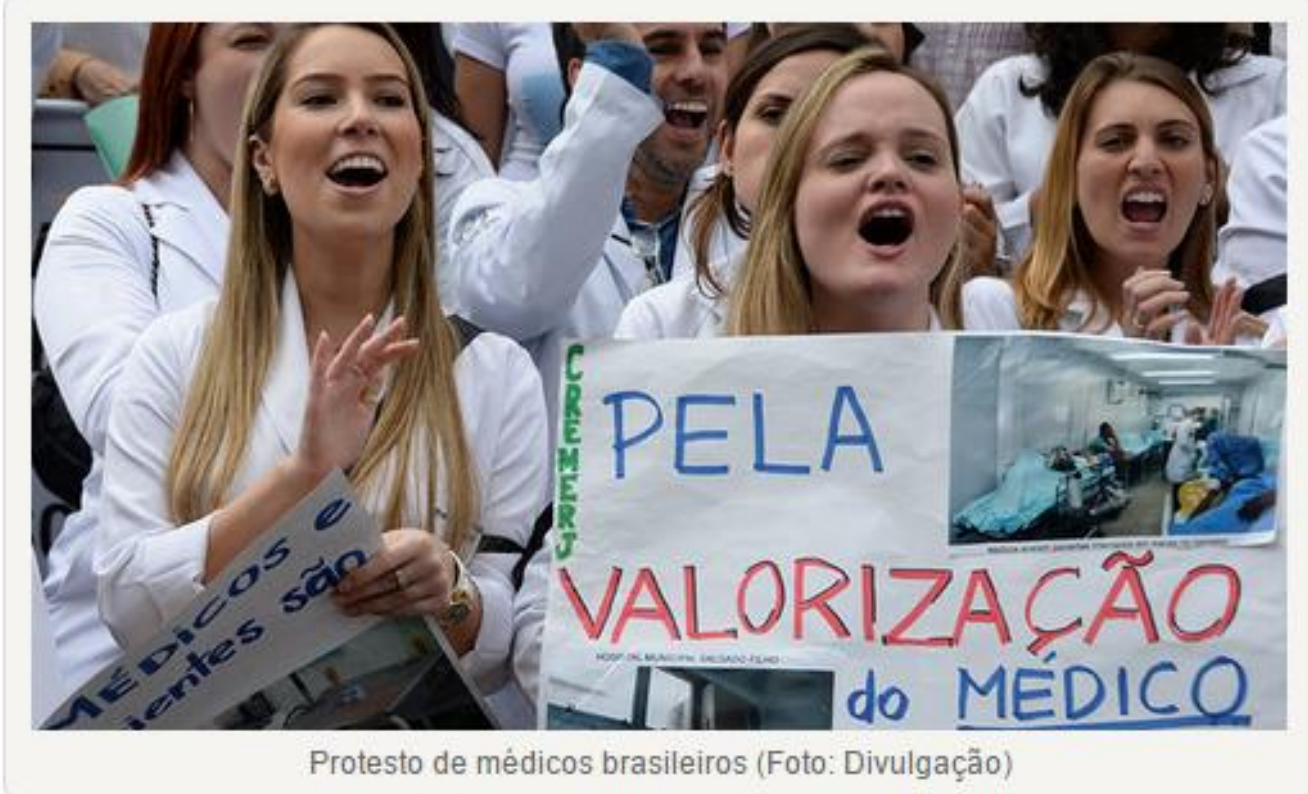


Mobilizações para exigir aumento dos honorários pagos pelos planos de saúde e campanhas para promover carreira de Estado são pautas frequentes nesses órgãos durante os últimos meses. Isso demonstra que os temas trabalhistas ganharam uma notoriedade insuspeita dentre os médicos.

\section{Leia também}

๑ Médicos cubanos no Haiti deixam o mundo envergonhado

๑ "Um dia vai precisar da gente e vou lembrar de sua linda fisionomia"

- Apelo à mídia: que fazer a respeito do despreparo dos nossos médicos?

- Médico brasileiro comenta 'gritaria' da mídia sobre médicos cubanos

Mas a última dessas batalhas do grêmio médico é, de longe, a mais complexa: o convite a médicos estrangeiros para trabalhar no território nacional. Esse assunto é particularmente sensivel porque atinge ao mesmo tempo o status outorgado pelo ingresso às escolas médicas, posturas políticas, questionamento da liderança e o temor de concorrentes novos no mercado de trabalho.

O ingresso às escolas médicas no Brasil acontece através de um penoso processo que visa excluir aqueles provenientes de camadas com menores recursos e oportunidades. Na visão oposta, trata-se da seleção dos "melhores", como se nessa lógica inversa a qualidade de um médico fosse garantida pela seleção que teve para entrar, e não pela formação adquirida dentro da escola médica.

Os médicos estrangeiros representam um desafio a esse paradigma: muitos países têm processos de seleção muito mais acessiveis para o ingresso. A seleção real acontece dentro da escola de medicina. Os alunos são constantemente avaliados, reprovados e jubilados, se necessário, durante o processo de formação médica. Diferentemente do que acontece no Brasil, entrar na escola de medicina não significa que o aluno será médico seis ou sete anos mais tarde.

A ênfase em outras latitudes é dada ao resultado final da educação; mais que o exame de ingresso, a avaliação crucial está na saída. Aqui, só o Conselho Regional de Medicina de São Paulo, CREMESP, avaliou os formandos de forma obrigatória em 2012. Menos da metade dos médicos foi aprovada nesse exame.

Mas não há consequências. O exame documentou a falsidade do mito de seleção dos "melhores", inclusive com um terço dos egressos de faculdades públicas reprovados, mas o mito permanece intacto. As paixões exacerbadas contra médicos brasileiros formados no exterior, particularmente em Cuba, estão relacionadas ao fato de eles encontrarem um atalho para ultrapassar a barreira de entrada nas faculdades de medicina.

A seleção de candidatos brasileiros para ingressar nas escolas de medicina para estrangeiros em Cuba foi canalizada no Brasil por movimentos sociais e partidos políticos ligados à esquerda. $\mathrm{A}$ ascensão do governo comandado por Luiz Inácio Lula da Silva foi a esperança dos egressos de Cuba que queriam regularizar sua situação no país. 
A resposta dos médicos não se fez esperar: as portas desses que não foram submetidos à seleção das faculdades brasileiras foram fechadas pelas próprias faculdades via revalidação.

Com algumas exceções, as universidades públicas, obrigadas por lei a atender essas revalidações, se omitiram, não respondiam ou criavam penosas vias sacras para quem ousasse seguir em frente com o processo.

Os médicos formados no exterior formaram um curioso bando de peregrinos que se encontravam em cada estado que finalmente voltava a receber a documentação ou realizava uma prova. A pressão dentro dos próprios aliados de esquerda do governo fez com que os ministérios da Saúde e da Educação criassem uma alternativa à qual podiam se adequar às universidades públicas para padronizar a revalidação.

O viés da primeira edição do exame, em 2010, foi vergonhoso. Chamado de Revalida, o exame acontece em duas etapas, uma teórica e outra prática. O nível de dificuldade foi tão grande que só dois, entre mais de 600 inscritos, formados em diferentes escolas médicas do mundo, foram chamados para a segunda fase. Os organizadores reconheceram que o nível de exigência foi além do necessário e prometeram reformular o exame.

Não existe nenhum critério para estabelecer algum grau de isonomia, como testar previamente o nível de dificuldade das perguntas em formandos de escolas brasileiras ou fazer um exame de igual teor ao realizado pelo CREMESP em 2012.

Cabe anotar que a peregrinação para os que queiram fazer o Revalida continua: por exemplo, o exame náo é oferecido no estado de São Paulo porque nenhuma universidade pública paulista aderiu a ele, mas o CREMESP obriga ao formado no exterior a ter seu diploma revalidado por esse exame numa norma prescrita para atender o clamor de seus fiscalizados nas ruas.

Nesse panorama, aparece um novo elemento: a distribuição desigual dos médicos na geografia nacional atinge níveis insustentáveis e se transforma em elemento político. Os médicos do Brasil, assim como os dos Estados Unidos ou outros países, se desinteressam pelo serviço nas cidades do interior e nas periferias das grandes cidades.

Há muitas razões para esse desinteresse: a formação médica acontece em ambientes tecnologicamente complexos muito diferentes da realidade desses locais carentes de recursos; as possibilidades de retorno financeiro parecem ligadas a especialidades que demandam mais recursos técnicos; e o atrativo natural que exercem as grandes cidades em sociedades individualistas em detrimento da vida bucólica do interior pode ser contada entre outras causas.

Mas a realidade da falta de atendimento médico fala mais alto. Os prefeitos se organizaram para pressionar por uma solução que trouxesse dividendos eleitorais e finalmente o governo comprou a causa. 
Houve várias tentativas. Inicialmente o governo ofereceu aos médicos recém-formados dinheiro e pontos a mais para os disputados exames de acesso à residência médica no programa Provab.

O estamento médico criticou a iniciativa, colocando argumentos como o de que o uso de pontos no exame seria uma chantagem para deixar um médico recém-formado abandonado à sorte no interior e sem nenhum tipo de supervisão.

Talvez estejam certos.

O problema pode ser deixar os pacientes abandonados a um médico recém-formado que não tem capacitação adequada para esses locais de atenção básica de baixa tecnologia. Locais em que a medicina cubana é especialista.

A medicina em Cuba usa um modelo diferente ao brasileiro. Está fundamentado em atenção básica e prevenção, com médicos acessíveis morando nas mesmas comunidades e um avanço tecnológico quase congelado após a queda da Cortina de Ferro.

Combinação contrastante que consegue atender a maioria de pacientes e obter excelentes estatísticas de saúde, comparáveis a qualquer país desenvolvido, a custo muito mais baixo. Mas, para a minoria dos pacientes, aqueles casos que requerem maior tecnologia, a receita pode ser insuficiente. A formação em grande escala de médicos permitiu que o país criasse as chamadas "Missiones" internacionais, que levaram atendimento médico a regióes carentes e remotas em dezenas de países.

Nos últimos anos, a exportação de serviços médicos se tornou a primeira fonte de divisas da ilha, principalmente pelas ações na vizinha Venezuela. A solução parece conveniente para todas as partes, médicos cubanos que estão dispostos a trabalhar no interior do Brasil e nas periferias para ajudar seu país e a população, que veria fim em sua espera por atendimento médico e estaria disposta a votar por quem fez isso acontecer. Mas há um obstáculo a vencer: a resistência do grêmio médico brasileiro.

Como vimos antes, os médicos brasileiros estavam ocupados em questões trabalhistas com seus principais empregadores, os planos de saúde e o governo. Em sua nova condição de classe trabalhadora, relativamente bem paga, mas trabalhadora, sua condição de fonte de ideias e de liderança dos tempos de classe média se extinguiram sob sua nova classe.

Em papel reativo, os médicos não conseguem elaborar contrapropostas para solucionar os problemas de falta de atendimento de saúde que sofre a maior parte da população.

A sua única resposta é que não trabalham no interior porque não tem plano de carreira nem condições de trabalhar. Uma continuação do repertório trabalhista anterior. Nenhuma proposta real para contrastar com as ideias do governo, que continua na liderança através de uma organizada campanha de mídia para angariar apoios e anunciando que estenderá os convites também a médicos espanhóis, portugueses e argentinos. 
A própria presidenta empenha sua palavra de trazer os médios como parte de sua estratégia para melhorar a saúde e acalmar as manifestações que tomaram conta do país.

O ministro da Saúde promete que as vagas só serão oferecidas a estrangeiros após serem recusadas por médicos brasileiros, promessa de quem tem certeza da recusa. As vagas, há tempos, aguardam por médicos brasileiros que as ocupem. Nesse cenário saem os médicos às ruas para protestar.

Os médicos estrangeiros a serem importados são o principal alvo em um protesto com pesado caráter trabalhista, de proteção de mercado. Porque a pior ameaça que os cubanos representam é que podem dar certo. Porque os cubanos podem demonstrar que a população não necessita de grandes hospitais de alta tecnologia, mas de médicos acessíveis que estejam ao seu lado.

“Ricardo Palacios é médico, formado no exterior com o diploma devidamente revalidado no Brasil, foi consultor temporário para projetos de pesquisa da Organização Mundial da Saúde e agora estuda Ciências Sociais na Universidade de São Paulo

O Texto 10 se inicia com uma nomeação que representa algo mais que um simples nome: autoriza um médico colombiano a refletir sobre o Programa Mais Médicos em seus diversos aspectos, assim como sobre as práticas sociais brasileiras que rodeiam a Medicina. Essa legitimidade decorre de sua formação estrangeira e "milagrosa" revalidação de seu diploma em terras tupiniquins.

O Dr. Ricardo Palacios representou em suas palavras o cerne desta pesquisa, com a propriedade de quem vivencia os prazeres e desgostos da Medicina Brasileira. Sua abordagem resvalou em todos os pontos que problematizaram este estudo. Da entrada no curso de graduação aos problemas enfrentados no mercado de trabalho, o médico colombiano fez a leitura que encerra as conlusões das análises aqui propostas.

Além disso, a foto que ilustra o texto reforça as críticas que o Dr. Ricardo Palácios fez ao sistema médico brasileiro. Se observarmos bem, a foto é preenchida por pessoas "bonitas" representantes da elite branca brasileira. Os cartazes pedem a valorização da profissão, o que parece contraditório diante dos altos salários recebidos e das recusas por vagas de trabalho. Ainda na foto, o cartaz segurado por uma suposta médica mostra um corredor de hospital cheio de pacientes, provavelmente o mesmo hospital que esses médicos da foto se recusariam a trabalhar.

A foto também traz uma pressuposição no cartaz que pede a valorização dos médicos. A imagem se refere a um suposto discurso de desvalorização dos médicos, ou seja, uma intertextualidade que não tem referências expressas. 
4.11 - TEXTO 11 - SERVIDORES RECEBEM EXTRA E DINHEIRO DO TÁXI PARA PARTICIPAR DE PROTESTO MÉDICO (Pragmatismo Político, publicado em 05/07/2013)

Figura 11 - Texto 11 - Servidores recebem extra e dinheiro do táxi para participar de protesto médico

\section{Servidores recebem extra e dinheiro do táxi para participar de protesto médico}

Entidade pagou táxi, dispensou seus funcionários mais cedo e ainda se dispôs a remunerar com hora extra quem participasse de protesto

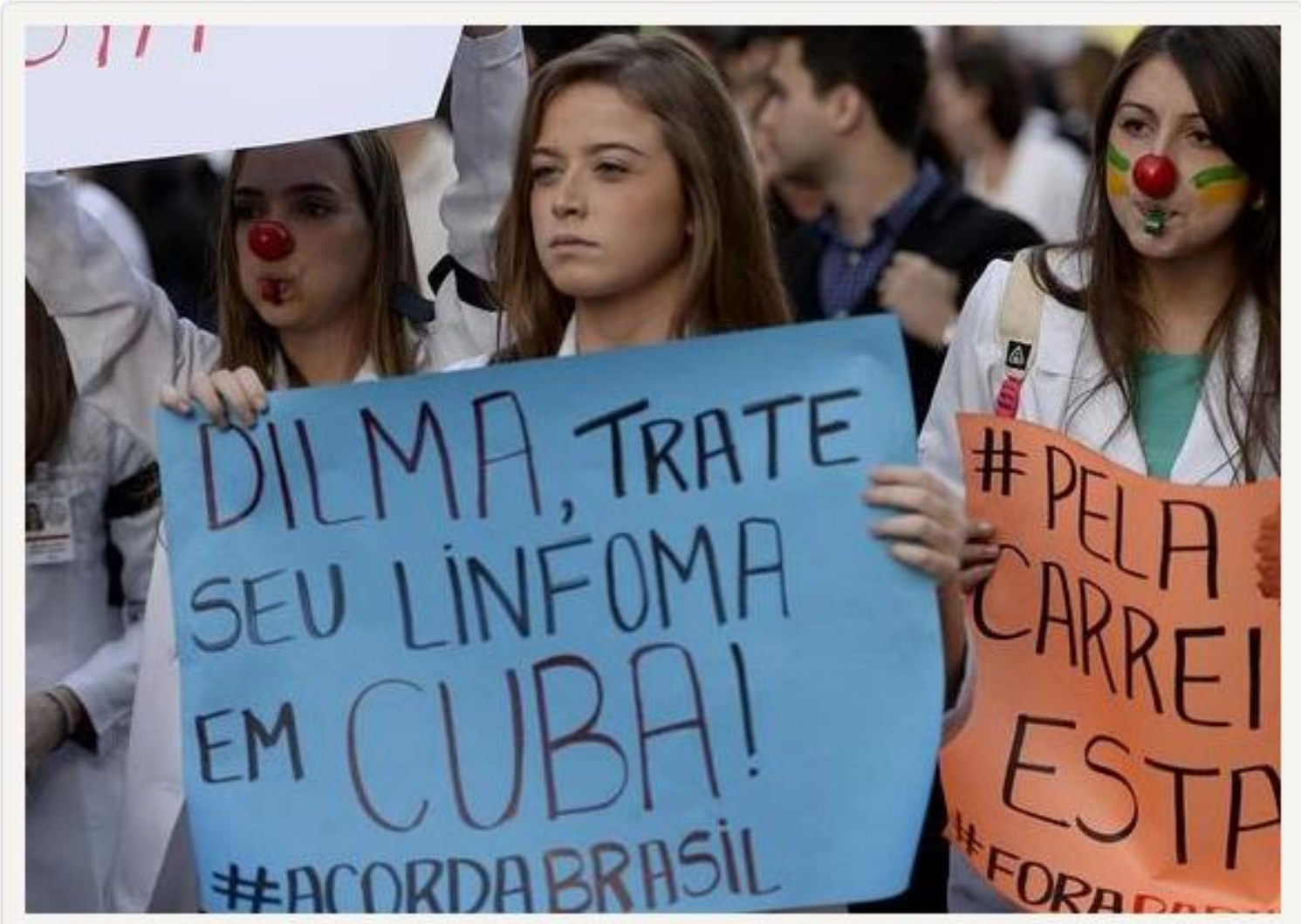

Cremesp paga táxi e hora extra para funcionários irem a ato de médicos na Paulista (Divulgação) 


\section{Renato Rovai, em seu blog}

Fábio Gomes, gerente operacional do Cremesp, enviou o seguinte email, na tarde de ontem, para a lista de funcionários da entidade:

Senhores chefes, gerentes e funcionários,

Em virtude da mobilização geral dos médicos agendada para hoje (dia 3 de julho), às 16h00, na Associação Médica Brasileira (Rua São Carlos do Pinhal, 324), convocamos os funcionários interessados em ajudar na realização desta atividade extraordinária.

Os interessados deverão procurar os funcionários da Seção de Eventos que estão alocados em frente da Sede da $A M B$ até às 16h00. Será concedida a utilização de boletos de taxi até a AMB.

Trajeto: O ponto de encontro será na Associação Médica Brasileira (Rua São Carlos do Pinhal, 324), de onde a passeata sairá, às $16 \mathrm{~h}$, rumo ao gabinete de representação da presidência da República, na avenida Paulista, 2163 ( esquina com rua Augusta; prédio do Banco do Brasil).

Solicitamos às chefias que dispensem os funcionários interessados em participar desta atividade extraordinária, bem como para disponibilizar boletos de táxi aos funcionários participantes.

As papeletas de horas extraordinárias pela participação deste evento deverão ser encaminhadas à Seção de Eventos.

\section{LEIA MAIS: Médico brasileiro comenta 'gritaria' da mídia sobre médicos cubanos}

Ou seja, a entidade pagou táxi, dispensou seus funcionários mais cedo e ainda se dispôs a remunerar com hora extra quem participasse da atividade. Fábio Gomes diz textualmente no comunicado da convocação que "as papeletas de horas extraordinárias pela participação deste evento deverão ser encaminhadas à Seção de Eventos".

Muitos dos que participaram do evento carregando cartazes, xingando Lula e Dilma e os médica protesto avenida paulista médicos cubanos na noite de ontem na Avenida Paulista não eram nem médicos e nem médicas. Mas funcionários das entidades representativas do setor. Você pode ter visto na Avenida Paulista escriturários, telefonistas, secretárias, administradores, motoristas usando jalecos brancos e/ou carregando cartazes. 
O blogue procurou a assessoria de imprensa do Cremesp questionando se a entidade incentivou de alguma forma o ato dos médicos na noite de ontem. A assessora informou que, por decisão em assembléia, o Cremesp apoiou a manifestação. Indagada se isso significava que funcionários da entidade foram liberados e receberam horas extras para participar do ato, a assessora disse que não tinha essa informação.

A atitude do Cremesp pode não ser ilegal, mas no mínimo é bastante questionável.

Vale registrar que a Rede Globo realizou ontem uma empolgada cobertura do evento. Não falou que a manifestação ao parar a Paulista afetou o atendimento nos hospitais da região e nem que atrapalhou a circulação de ambulâncias.

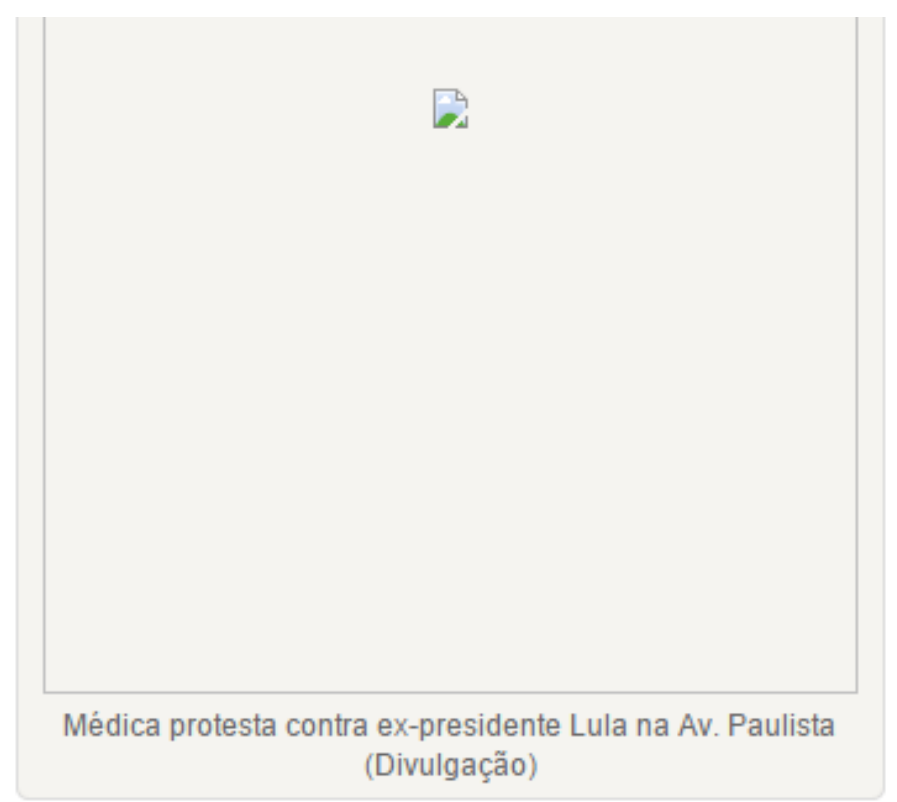

E mais do que isso, no Jornal da Globo os cartazes atacando Lula e Dilma foram a estrela da reportagem e ainda se registrou que haviam 5 mil médicos na manifestação. Estive na Paulista e vi o ato. Com muita generosidade, não havia 2 mil pessoas ali. E agora, como se sabe, boa parte não era nem médico e nem estudante de medicina.

O debate sobre a saúde no Brasil não pode ser exclusivo de uma única categoria. Há muitos problemas no setor, mas um deles é sim a forma como boa parte da classe médica brasileira se acostumou a atender apenas em áreas centrais. Além disso, é preciso moralizar o setor. Muitos administradores dizem que têm que fazer vistas grossas para o uso de artimanhas por médicos que são contratados para prestar uma quantidade de horas de serviço e não cumprem nem 1/3 do combinado. Os que tentam enfrentar esses esquemas, são chantageados exatamente porque faltam médicos no Brasil.

Criar novas universidades nesta área é a melhor solução, mas demanda tempo. E as pessoas que estão doentes hoje não podem esperar. Por isso, abrir o país para receber mais profissionais desse segmento é uma iniciativa razoável. Outra, seria criar cursos de especialização para outros profissionais de saúde brasileiros em clínica geral. Exatamente o oposto do que os médicos querem. Eles defendem o Ato Médico, que impede até que um paciente tome uma vacina de uma campanha do governo se não passar antes por um médico. E que limitará a ação, por exemplo, de psicólogos, fisioterapeutas e nutricionistas, entre outros profissionais da saúde. O Ato Médico acaba de ser aprovado por pressão dos médicos no Congresso.

Não faz muito tempo, um esquema de uso de dedos de silicone foi utilizado por médicos de Ferraz de Vasconcelos para garantir a presença de médicos ausentes. O "incentivo" que o Cremesp deu aos seus funcionários para serem médicos por uma noite na Paulista é diferente do dedo de silicone. Mas ao mesmo tempo é a mesma coisa. É falsificar a verdade de uma manifestação. 
O Texto 11 se inicia com uma intertextualidade manifesta da forma mais explícita possível, a reprodução da íntegra do texto que será na sequência contestado. Isso deixa clara a abertura da diferença que caracteriza a intertextualidade manifesta. No caso em pauta, a percepção dos atores representados não deixa dúvidas de quais vozes serão articuladas. De um lado temos o Conselho Regional de Medicina de São Paulo, do outro, o autor que combate a prática questionável dessa instituição.

Mais adiante no texto, outra intertextualidade é revelada por meio do diálogo realizado entre o blogue responsável pela denúnica e o Cremesp. O cabo de guerra não apresenta resultado, e o bolgue finaliza o diálogo avaliando como questionável a atuação da instituição médica, como veremos no exemplo seguinte.

\section{Exemplo (28)}

"O blogue procurou a assessoria de imprensa do Cremesp questionando se a entidade incentivou de alguma forma o ato dos médicos na noite de ontem. A assessora informou que, por decisão em assembléia, o Cremesp apoiou a manifestação. Indagada se isso significava que funcionários da entidade foram liberados e receberam horas extras para participar do ato, a assessora disse que não tinha essa informação. A atitude do Cremesp pode não ser ilegal, mas no mínimo é bastante questionável". (Intertextualidade)

Outra intertextualidade se apresenta quando o autor do texto se refere a uma publicação da Rede Globo referente à manifestação questionada. No caso, Renato Rovai salienta que a emissora omitiu informações acerca do evento ocorrido, insinuando uma manipulação da informação. Mais que isso, o autor em sua análise se refere às diversas formas de representar o mundo, quando relata que o foco da notícia veiculada pela Globo não abordava aspectos de interesse coletivo imbuídos de responsabilidade social.

\section{Exemplo (29)}

"Vale registrar que a Rede Globo realizou ontem uma empolgada cobertura do evento. Não falou que a manifestação ao parar a Paulista afetou o atendimento nos hospitais da região e nem que atrapalhou a circulação de ambulâncias.

E mais do que isso, no Jornal da Globo os cartazes atacando Lula e Dilma foram a estrela da reportagem e ainda se registrou que haviam 5 mil médicos na manifestação. Estive na Paulista e vi o ato. Com muita generosidade, não havia 2 mil pessoas ali. E agora, como se sabe, boa parte não era nem médico e nem estudante de medicina".

No três últimos parágrafos do Texto 11, o autor trabalha a legitimação por racionalização que apresenta os pontos positivos do Programa Mais Médicos conforme 
o discurso apresentado em todos os textos anteriores publicados pelo Pragmatismo Político. De forma resumida ele consegue fazer uma abordagem das intenções do programa realmente relevantes para sua avaliação. $\mathrm{O}$ autor apresenta argumentos racionais que caracterizam a base para a legitimação do programa. Em poucas palavras ele empreende um discurso de oposição aos/às médicos/as e tudo aquilo que eles sustentaram na tentativa de deslegitimar o Programa Mais Médicos. Na articulação do raciocínio, Renato Rovai tanto apresenta soluções quanto critica algumas práticas médicas.

\section{Exemplo (30)}

“O debate sobre a saúde no Brasil não pode ser exclusivo de uma única categoria. Há muitos problemas no setor, mas um deles é sim a forma como boa parte da classe médica brasileira se acostumou a atender apenas em áreas centrais. Além disso, é preciso moralizar o setor. Muitos administradores dizem que têm que fazer vistas grossas para o uso de artimanhas por médicos que são contratados para prestar uma quantidade de horas de serviço e não cumprem nem 1/3 do combinado. Os que tentam enfrentar esses esquemas, são chantageados exatamente porque faltam médicos no Brasil". (Racionalização) 


\subsection{2 - TEXTO 12 - MEDICINA É PROFISSÃo COM MAIOR SALÁRIO E MENOS} PROFISSIONAIS (Pragmatismo Político, publicado em 03/07/2013)

Figura 12 - Texto 12 - Medicina é profissão com maior salário e menos profissionais

MERCADO [" 03/JUL/2013 ÀS 18:43 24 COMENTÁRIOS

\section{Medicina é profissão com maior salário e menos profissionais}

Medicina é carreira com maior remuneração e escassez de profissionais, revela estudo do Ipea. Ranking avaliou 48 profissöes. Confira abaixo

Medicina é a carreira de ensino superior com o melhor desempenho trabalhista e com maior escassez de profissionais, revelou estudo do Ipea (Instituto de Política Econômica Aplicada) divulgado nesta quarta-feira (3).

Um ranking criado pelo instituto considerando quatro variáveis -salários, jornada de trabalho, cobertura previdenciária e taxa de ocupação- mostrou que os médicos têm o melhor resultado global.

Considerando dados de 48 profissões de todo o país, medicina é a carreira que oferece o maior salário médio ( $R \$ 6.940,12)$ e a maior taxa de ocupação ( $91,8 \%$ dos profissionais estão trabalhando). Além disso, possui a décima maior cobertura previdenciária: $90,7 \%$ dos trabalhadores tem algum plano de aposentadoria, seja público ou privado.

O bom desempenho da categoria nesses três critérios compensou o posicionamento ruim no ranking de jornada de trabalho. Dos 48 grupos de profissionais analisados, o de médico é o quarto que mais trabalha. Sua jornada média semanal é de 42,03 horas.

De acordo com Marcelo Neri, ministro interino da Secretaria de Assuntos Estratégicos da Presidência da República e presidente do Ipea, os números revelam que há uma escassez de médicos no país.

Ele disse que o estudo busca dar informações úteis para elaboração de políticas públicas que ataquem esse problema, mas ressaltou que a pesquisa teve início antes da presidente Dilma Rousseff propor a importação de médicos de outros países, não tendo intuito de corroborá-la. 
Neri indicou, porém, que a atração de "talentos" do exterior pode ser interessante se feita tomando o cuidado de trazer profissionais de qualidade e de preservar os direitos dos médicos brasileiros.

Para Neri, a falta de profissionais é um bom problema, muito melhor do que crise de desemprego.

\section{Leia também}

$\oplus$ Médicos dos EUA avaliam sistema de saúde cubano

๑ Fotógrafo emociona ao clicar mulheres que tiveram câncer de mama

๑ Médico brasileiro comenta 'gritaria' da mídia sobre médicos cubanos

"A maior gravidade desse problema é que para você formar pessoas com qualidade demora tempo. Os indicadores não deixam dúvidas de que faltam médicos", afirmou.

Neri destacou que a distribuição de médicos não é homogênea no país. Há um grande número de profissionais no Sudeste e uma enorme carência principalmente na região Norte, quando comparado o número de médicos com o tamanho da população dessas regiões.

\section{TRANSPORTE}

Segundo Neri, o estudo do Ipea aponta também para um desafio no enfrentamento das demandas da população por transporte público de qualidade. A carreira de serviços de transporte aparece em quinto lugar no ranking de desempenho trabalhista, indicando que também faltam profissionais na área.

Outras profissões com bom desempenho no ranking são odontologia, engenharias civil, metalúrgica e mecânica e estatística.

Na outra ponta, amargando as piores colocações no ranking estão profissionais graduados com formação ligada a religião, serviços domésticos e de beleza, filosofia, ciências sociais e físicas. De acordo com Neri, muitas delas estão ligadas à carreira de magistério, indicando a baixa valorização da carreira de professor.

\begin{tabular}{|c|c|c|c|c|}
\hline $\begin{array}{l}\text { Ranking por } \\
\text { salário }\end{array}$ & Carreira & $\begin{array}{l}\text { Salário } \\
\text { Mensal }\end{array}$ & $\begin{array}{l}\text { Jornada (horas } \\
\text { semanais) }\end{array}$ & $\begin{array}{c}\text { Ranking por } \\
\text { jornada }\end{array}$ \\
\hline $1^{\circ}$ & Medicina & RS $6.940,12$ & 42,03 & 45 \\
\hline $2^{\circ}$ & Estatistica & RS $5.416,10$ & 39,05 & 20 \\
\hline $3^{\circ}$ & Engenharia civil & RS $4.604,41$ & 41,74 & 43 \\
\hline $4^{\circ}$ & Engenharia quimica & RS $4.549,12$ & 41,53 & 40 \\
\hline $5^{\circ}$ & Serviços de transportes & RS $4.460,89$ & 41,91 & 44 \\
\hline $6^{\circ}$ & Setor militar e de defesa & RS $4.433,67$ & 42,46 & 47 \\
\hline $7^{\circ}$ & Engenharia mecânica e metalurgica & RS $4.258,69$ & 40,96 & 32 \\
\hline $8^{\circ}$ & Odontologia & RS $4.238,65$ & 37,46 & 12 \\
\hline $9^{\circ}$ & Arquitetura e urbanismo & RS $4.206,01$ & 39,78 & 24 \\
\hline $10^{\circ}$ & Engenharia (outros) & RS $4.168,05$ & 41,01 & 34 \\
\hline $11^{\circ}$ & Direito & RS $4.104,84$ & 38,94 & 18 \\
\hline
\end{tabular}




\begin{tabular}{|l|l|l|l|l|}
\hline $12^{\circ}$ & Engenharia naval e aeronautica & RS $4.089,29$ & 42,85 & 48 \\
\hline $13^{\circ}$ & Economia & RS $3.914,51$ & 40,58 & 28 \\
\hline $14^{\circ}$ & Veterinária & RS $3.782,46$ & 41,43 & 39 \\
\hline $15^{\circ}$ & Engenharia elétrica e automação & RS $3.734,10$ & 41,73 & 42 \\
\hline $16^{\circ}$ & Sociologia e ciência polìica & RS $3.672,37$ & 38,45 & 17 \\
\hline $17^{\circ}$ & Comunicação social (jornalistas) & RS 3.655,01 & 39 & 19 \\
\hline $18^{\circ}$ & Psicologia & RS 3.529,77 & 35,68 & 3 \\
\hline $19^{\circ}$ & Marketing e publicidade & RS 3.517,69 & 40,98 & 33 \\
\hline $20^{\circ}$ & Artes & RS 3.229,36 & 37,43 & 11 \\
\hline $21^{\circ}$ & Biblioteconomia & RS 3.140,29 & 38,08 & 16 \\
\hline $22^{\circ}$ & Outras ciências físicas (gerais) & RS 3.124,56 & 34,41 & 1 \\
\hline $23^{\circ}$ & Outras ciências sociais & RS 3.102,22 & 37,27 & 9 \\
\hline $24^{\circ}$ & Administração - diversos & RS 3.057,31 & 41,27 & 37 \\
\hline $25^{\circ}$ & Agronomia, pecuária e pesca & RS $2.964,62$ & 42,06 & 46 \\
\hline $26^{\circ}$ & Farmácia & RS $2.964,38$ & 40,88 & 31 \\
\hline $27^{\circ}$ & Física & RS 2.961 .39 & 37.97 & 15 \\
\hline
\end{tabular}

\begin{tabular}{|c|c|c|c|c|}
\hline $28^{\circ}$ & Computação & RS $2.886,57$ & 40,73 & 30 \\
\hline $29^{\circ}$ & Turismo, viagens e lazer & RS $2.884,15$ & 40,26 & 27 \\
\hline $30^{\circ}$ & Administração e secretariado & RS $2.866,27$ & 41,07 & 35 \\
\hline $31^{\circ}$ & Engenharia, produção e processamento & RS $2.785,79$ & 41,72 & 41 \\
\hline $32^{\circ}$ & Serviços de segurança & RS $2.785,47$ & 41,41 & 38 \\
\hline $33^{\circ}$ & Outras - saúde (reabilitação) & RS $2.609,16$ & 36,45 & 5 \\
\hline $34^{\circ}$ & Química & RS $2.606,01$ & 39,9 & 25 \\
\hline $35^{\circ}$ & Contabilidade e atuariais & RS $2.588,04$ & 41,07 & 36 \\
\hline $36^{\circ}$ & Biologia e ciências da vida & RS $2.454,90$ & 37,38 & 10 \\
\hline $37^{\circ}$ & Serviço social & RS $2.428,14$ & 36,58 & 6 \\
\hline $38^{\circ}$ & Educação fisica e esportes & RS $2.423,49$ & 39,72 & 23 \\
\hline $39^{\circ}$ & História e arqueologia & RS $2.304,05$ & 36,97 & 7 \\
\hline $40^{\circ}$ & Enfermagem & RS $2.282,46$ & 39,32 & 22 \\
\hline $41^{\circ}$ & Filosofia e ética & RS $2.261,28$ & 37,67 & 13 \\
\hline $42^{\circ}$ & Letras, linguas e culturas & RS $2.228,33$ & 35,98 & 4 \\
\hline $43^{\circ}$ & Matemática & RS $2.216,96$ & 37,69 & 14 \\
\hline $44^{\circ}$ & $\begin{array}{l}\text { Outros serviços pessoais (beleza e } \\
\text { domésticos) }\end{array}$ & RS $2.205,83$ & 39,3 & 21 \\
\hline $45^{\circ}$ & Proteção ambiental & RS $2.187,21$ & 40,03 & 26 \\
\hline $46^{\circ}$ & Geologia e ciências da terra & RS 2.181,34 & 37,14 & 8 \\
\hline $47^{\circ}$ & Educação e formação de professores & RS $1.844,29$ & 35,52 & 2 \\
\hline $48^{\circ}$ & Religião & RS $1.413,01$ & 40,71 & 29 \\
\hline
\end{tabular}

No Texto 12, a categoria linguístico-discursiva que mais se destaca é a intertextualidade manifesta. $\mathrm{O}$ texto faz referência expressa a um estudo do Instituto de Pesquisa Econômica Aplicada (IPEA) como argumento central de sua exposição. Há ainda a utilização de assimilações e nomeações que contribuem para a sustentação da 
ideia de que os/as médicos/ "reclamam de barriga cheia". Vejamos nos exemplos seguintes.

\section{Exemplo (31)}

"De acordo com Marcelo Neri, ministro interino da Secretaria de Assuntos Estratégicos da Presidência da República e presidente do Ipea, os números revelam que há uma escassez de médicos no país". (Nomeação)

\section{Exemplo (32)}

"Considerando dados de 48 profissões de todo o país, medicina é a carreira que oferece o maior salário médio $(\mathbf{R} \$ 6.940,12)$ e a maior taxa de ocupação $(91,8 \%$ dos profissionais estão trabalhando). Além disso, possui a décima maior cobertura previdenciária: $\mathbf{9 0 , 7 \%}$ dos trabalhadores tem algum plano de aposentadoria, seja público ou privado". (Assimilação)

O título da matéria contém dois discursos, marcando também a interdiscursividade, ou intertextualidade constitutiva, de acordo com Fairclough (2001). Primeiramente ele representa que os/as médicos/as têm bons salários e, portanto, não podem reclamar desse aspecto da profissão. Em segundo lugar, o título afirma que medicina é a profissão com menos profissionais, indo de encontro ao argumento principal dos/as médicos/as contrários/as ao Programa Mais Médicos: "não faltam profissionais, faltam condições de trabalho".

\section{Exemplo (33)}

“MEDICINA É PROFISSÃo COM MAIOR SALÁRIO E MENOS PROFISSIONAIS".

"Medicina é carreira com maior remuneração e escassez de profissionais, revela estudo do Ipea. Ranking avaliou 48 profissões” (Intertextualidade) 


\section{CONSIDERAÇÕES FINAIS}

Retomando as questões de pesquisa, podemos observar que as análises mostraram uma diferença na representação dos/as médicos/as brasileiros/as entre os dois veículos estudados. Enquanto o discurso do CFM sugere a superioridade dos/as nossos/as profissionais, o discurso do PP reconhece a qualidade dos/as médicos/as estrangeiros/as e ressalta a importância das contratações feitas pelo Programa Mais Médicos. Basta observar que nos textos do Portal Médico os/as médicos/as cubanos/as raramente são chamados/as de médicos/as, utilizando-se na maioria das vezes expressões como 'intercambistas' e 'portadores de diploma adquirido no exterior'. Ao contrário, o Pragmatismo Político, independentemente da nacionalidade, se refere a todos/as como médicos/as.

Claramente, o Portal Médico menciona uma qualidade superior na prestação de serviços pelos/as médicos/as brasileiros/as na medida em que defende a fiscalização apenas dos/as estrangeiros/as que trabalham no Programa Mais Médicos. Ademais, o Portal Médico posiciona os/as estudantes brasileiros/as de medicina à frente de médicos/as formados/as no exterior.

No caso dos/as médicos/as cubanos/as a discriminação é mais notável. O Conselho Federal de Medicina trabalha a concepção do/a médico/a cubano/a como um 'prático', que, supostamente, não tem conhecimento científico suficiente para exercer a medicina no Brasil. A todo tempo a qualidade da medIcina cubana é colocada em dúvida. Em

síntese, o CFM defende que a contratação de médicos/as cubanos/as coloca em risco a saúde do/a paciente brasileiro/a.

Ainda que pouco citados nos textos em análise, os/as médicos/as de outras nacionalidades são também diferenciados/as dos/as médicos/as brasileiros/as. No geral, são representados/as como "portadores de diploma estrangeiro". Porém, no discurso do Portal Médico, a distinção não fica clara entre as nacionalidades, pois os/as profissionais estrangeiros/as quase sempre são representados/as como cubanos/as. No Pragmatismo Político há pouca referência a estrangeiros/as, pois seu discurso é mais focado nas qualidades do programa em detrimento dos profissionais que nele atuam. Quando se refere a outras nacionalidades o site aborda a medicina estrangeira em geral, ressaltando a importância de associar experiências globais.

Sobre as vozes articuladas nos textos é possível perceber as intenções de cada veículo. O CFM articula vozes única e exclusivamente de médicos/as ou pessoas ou 
grupos de interesse, reforçando o discurso hegemônico de que o programa deve ser feito levando em consideração prioritariamente as demandas da classe médica. Defendem discursos no sentido de que o programa é eleitoreiro, que o Governo colocou a população contra os/as médicos/as, que as demandas do setor são de ordem fianceira e que não precisamos de mais médicos/as, mas sim, de mais financiamento. Em nenhum momento o CFM representa a voz do povo ou dos/as médicos/as estrangeiros/as, dando a entender que os/as principais interessados/as no programa são os/as médicos/as brasileiros/as.

O Pragmatismo Político tem uma atuação mais jornalística. O site procura ouvir fontes diversas e, por mais que tenha uma inclinação para a esquerda, articula vozes variadas relativas ao alcance do programa. Logo, torna mais horizontal a distribuição de papéis nas representações feitas no contexto do Programa Mais Médicos. Ele defende uma postura a favor dos mais empobrecidos, trazendo como fator principal dos debates a necessidade de disponibilizar médicos/as para quem não tem acesso. Sustenta também uma postura de combate à mercantilização dos tratamentos de saúde, atacando práticas excludentes que impedem o acesso à saúde por pessoas menos favorecidas.

Pode-se perceber que as ideias sustentadas pelos dois veículos representam posições divergentes quanto ao Programa Mais Médicos. O Portal Médico se empenha na manutenção de relações assimétricas de poder, enquanto o Pragmatismo Político defende o rompimento de tais forças e a consequente dissolução de desigualdades sociais.

Um levantamento da presença do termo "Mais Médicos" nos títulos das publicações coletadas nos dois veículos no período de um ano, demonstra a tendência de ataque ao programa por parte do Portal Médico, como podemos perceber no quadro do anexo 1. Em suas manchetes, houve a oocrrência de 50 "Mais Médicos" em um total de 122 notícias, o que representa aproximadamente 41\%. Por parte do Pragmatismo Político a incidência foi de 12 títulos em 93 matérias, o que representa aproximadamente $13 \%$. Portanto, percebemos que as abordagens dos dois veículos possuem vestígios claros de tendências antagônicas.

Enquanto o Pragmatismo Político atua a favor da diminuição de desigualdades sociais relativas aos serviços de atendimento médico brasileiros, o Portal Médico favorece a manutenção de relações de poder assimétricas por meio de discursos que blindam a classe médica e favorecem a preservação de práticas excludentes.

A análise do corpus ampliado evidencia a tendência do Portal Médico em desqualificar os/as médicos/as cubanos/as e manter o poder hegêmonico dos/as médicos/as brasileiros/as. Dos 122 textos publicados pelo portal, 13 fazem ataque direto 
aos/às médicos/as da ilha de Fidel. Em resposta a esses apelos, o Pragmatismo Político é incisivo na defesa desses/as profissionais. Das suas 93 publicações, 42 ressaltam os pontos positivos da contratação de cubanos/as ou relatam histórias que demonstram o amor pela profissão e solidariedade desses/as médicos/as.

Enquanto o Portal Médico avalia que o Programa Mais Médicos é eleitoreiro, ele não percebe que sua atuação é mais política do que o suposto caráter "eleitoreiro" do programa. Nos seis textos de autoria do CFM analisados no corpus principal estão presentes ataques ao Governo Federal. Isso reforça a constatação de que o foco dos/as médicos/as não é o programa em si, mas a preservação de privilégios no exercício da medicina e a manutenção do poder hegemônico nos tratamentos de saúde.

No caso do Pragmatismo Político, três dos seis textos analisados no corpus principal ressaltam características positivas do programa e sua necessidade imediata. Nenhum texto fala do governo ou do programa como mérito do governo.

Por fim, é notável a mudança discursiva do início para o fim do período de análises. Como ressaltado no início deste trabalho, os/as médicos/as brasileiros/as iniciaram o combate ao programa com argumentos desproporcionais, que mencionavam tópicos como o regime trabalhista, os trâmites legais de sua implemetação, o baixo salário pago aos/às cubanos/as, entre outros. Esqueceram de observar, no impulso da preservação de seus interesses, as carências reais de profissionais nas áreas alvo do programa.

Passado um ano, o CFM já concordava com a permanência dos/as cubanos/as, porém, com imposições que continuavam dificultando as relações profissionais. Um dos casos mais emblemáticos foi a permissão para os/as cubanos/as realizarem trabalhos administrativos nos hospitais, fato esse que confirma o olhar de superioridade em relação aos/às profissionais estrangeiros/as.

Uma análise geral mostra a pretensão dos/as médicos brasileiros/as em manter seu status quo, fato que pode ser observado por suas representações sobre o Programa Mais Médicos. No entanto, estudos deste tipo são capazes de combater tais assimetrias de poder e posicionar o cidadão de forma a buscar seus direitos garantidos pelo Estado. Assim, finalizo essas explanações ressaltando que o estudo aqui desenvolvido tem caráter de contribuição para a redução das desigualdades, ao mesmo tempo que se caracteriza como inicio de uma pesquisa em andamento, que está aberta a contribuições de outros estudos. 


\section{REFERÊNCIAS BIBLIOGRÁFICAS}

ADAM \& HERZLICH. Sociologia da doença e da medicina. Bauru, SP: EDUSC, 2001.

BAKHTIN, M. Marxismo e filosofia da linguagem. São Paulo, Hucitec. 1986.

BAKHTIN, M. Estética da criação verbal. São Paulo: Martins Fontes, 1997[1953].

BOURDIEU, P. A economia das trocas simbólicas. São Paulo, Mercado das Letras. 1992.

CASTELLS, M. (2002). A sociedade em rede. Lisboa: Fundação Calouste Gulbenkian.

CHOULIARAKI L \& FAIRCLOUGH, N. (2002) Discourse in late modernity: rethinking critical discourse analysis. Edinburgh: Edinburgh University Press.

DIAS, Juliana F. O renascimento do parto: Discurso e Identidade. Brasília, Universidade de Brasília, 2007.

FAIRCLOUGH, N. Analysing discourse: textual analysis for social research. London: Routledge, 2003a.

FAIRCLOUGH, N. Discurso e Mudança Social. (Coord. da trad.) Izabel Magalhães. Brasília: UNB, 2001.

FOUCAUlT, M. A ordem do discurso. 7 ed. São Paulo: Loyola, 2001. (Leituras Filosóficas).

FREITAS, M. Teresa A. (1994). O pensamento de Vygotsky e Bakthin no Brasil. Campinas, SP: Papirus.

HABERMAS, Jürgen. Mudança estrutural da esfera pública: investigações quanto a uma categoria da sociedade burguesa. Trad.: Flávio R. Kothe. Rio de Janeiro: Tempo Brasileiro, 2003.

HALL, Stuart. A identidade cultural na pós-modernidade. DP\&A Editora. Rio de Janeiro. 2006 
HALLIDAY, M. A. K. Introduction to Functional Grammar. London: Edward Arnold, 1985.

KOCH, Ingedore G. V. 1999. Argumentação e linguagem. São Paulo, Cortez.

KRESS, G. Critical Discourse Analysis. In:W. G. (org.). Annual Review of Applied Linguistics 11. p. 84-99, 1990.

MAGALHÃES, I. 1996. Linguagem e identidade em contextos institucionais e comunitários. Cadernos de linguagem e sociedade. Brasília DF, 2 (1): 42 - 61

OLIVEIRA, N. A. Ensino médico no Brasil: desafios e prioridades, no contexto do SUS: um estudo a partir de seis estados brasileiros - Rio de Janeiro, 2007. Tese (doutorado) Instituto Oswaldo Cruz, Ensino em Biociências e Saúde, 2007.

ORLANDI, E. A análise de discurso e seus entremeios: notas para a sua história no Brasil. Caderno de Estudos Lingüísticos (42), Campinas: Jan./Jun. // PÊCHEUX, Michel. Semântica e Discurso, Campinas: Unicamp, 2002.

PEREIRA JUNIOR, L.C. A apuração da notícia: métodos de investigação na imprensa. Petrópolis, RJ: Vozes, 2006.

PIERANTI, O.P. Políticas públicas para radiodifusão e imprensa: ação e omissão do Estado no Brasil pós - 1964. Rio de Janeiro, FGV, 2007.

RAMALHO, V - RESENDE, V M. Análise de Discurso (para a) Crítica: o texto como material de pesquisa. Coleção: Linguagem e Sociedade Vol. 1 - Campinas, SP: Pontes, 2011.

RAMALHO, Viviane. Análise de discurso crítica da publicidade: um estudo sobre a promoção de medicamentos no Brasil. Covilhã: Livros LabCom, 2010. Disponível em: http://www.livroslabcom.ubi.pt/sinopse/ramalho-analise-2010.html. Acesso em $02 \mathrm{fev}$. 2013.

RAMALHO, Viviane. Gêneros discursivos e ideologia: elementos para estudos críticos In: MELO, Iran (org.). Introdução aos estudos críticos do discurso: teoria e prática. Cmpinas: Pontes, 2012, p. 139-187.

RAMALHO, V - RESENDE, V M. Análise de Discurso Crítica. 2. Ed., 1 reimpressão. São Paulo: Contexto, 2013. 
RESENDE, Viviane de Melo \& RAMALHO, Viviane. Inequality and representation: critical ciscourse analysis of news coverage about homelessness In: PASCALE, M. (org.) Social inequality \& the politics of representation: a global landscape. California: SAGE, 2012, v.1, p. 21-34.

THOMPSON, John B. Ideologia e cultura moderna: teoria social crítica na era dos meios de comunicação de massa. 9.ed. - Petrópolis, RJ: Vozes, 2011.

VAN DIJK, T. Semântica do discurso. In: PEDRO, E. R. (Org.) Análise crítica do discurso: uma perspectiva sociopolítica e funcional. Lisboa: Caminho, 1997, p. 169-222.

VAN DIJK, T. Discurso e Poder. Org.: Judith Hoffnagel, Karina Falcone. 2. Ed., 1reimpressão - São Paulo: Contexto, 2012.

WOLF. M. Teoria das comunicações de massa. Trad. Karina Jannini - São Paulo: Martins Fontes, 2003. 
ANEXOS

ANEXO 1

Quadro (10) - Demonstrativo de textos que representam especificamente os/as médicos/as cubanos/as PORTAL MÉDICO

Cubanos abandonam programa reclamando de falta de pagamento 04/06/2014

Cubanos fogem da Bolívia e pedem asilo no Brasil 27/03/2014

Mais Médicos promove o "neoescravagismo" no Brasil, diz ives Gandra 17/02/2014

Portaria do Mais Médicos reforça teoria de trabalho escravo, denuncia Fenam 14/02/2014

Mais três cubanos na BA, PE e MA abandonam programa do governo 12/02/2014

Ministério público diz que médica Cubana tem razão e que salário deve ser pago na íntegra 07/02/2014

OMS e OIT recebem denúncia de ilegalidades no recrutamento de profissionais estrangeiros do

programa Mais Médicos 21/11/2013

CFM recorrerá a OMS contra contratação de médicos cubanos 03/10/2013

CFM aponta violação de direitos humanos na contratação de cubanos 02/10/2013

Entidades condenam acordos que abrem brechas à "semiescravidão" de médicos 28/08/2013

CFM denuncia Governo Federal por restrição de liberdade de médicos cubanos 23/08/2013

Conselheiro rebate importação de médicos cubanos na Globonews e Band Entrevista 22/08/2013

Para CFM, importação de médicos cubanos é medida eleitoreira e irresponsável 21/08/2013

\section{PRAGMATISMO POLÍTICO}

Carta de um médico cubano: respeito, solidariedade e ética 19/07/2013

Duas médicas explicam porque aceitaram o Mais Médicos 13/08/2013

Maioria dos médicos cubanos vão para o norte e nordeste 23/08/2013

Médicos cubanos no Brasil: "viemos por solidariedade, não por dinheiro"25/08/2013

Revista Veja aplaudiu médicos cubanos na época de FHC 26/08/2013

Vídeo: médicos brasileiros ofendem médicos cubanos 27/08/2013

"Vou orientar meus médicos a não socorrerem erros dos médicos cubanos" 27/08/2013

Jornalista diz que médicas cubanas "parecem empregadas domésticas" 27/08/2013

Os “escravos cubanos" perturbam os médicos brasileiros 27/08/2013

Médicos cubanos recebem flores um dia após agressões 28/08/2013

Cubano xingado por jovens médicas brasileiras comenta o episódio 28/08/2013

Como foi a primeira passagem dos cubanos no Brasil em 1999? 28/08/2013

Cubanos são os médicos mais respeitados em operações internacionais 29/08/2013

Médicos cubanos não são escravos; entenda 30/08/2013

Médicos brasileiros ofendem cubanos e retiram cama de dormitório 02/09/2013

"Brasil é medicalocêntrico", diz médica brasileira formada em Cuba 03/09/2013

A comovente carta de desligamento da médica Rafaela Pacheco 04/09/2013

Prefeito da cidade com pior IDH celebra chegada de médicos cubanos 05/09/2013

Lula sobre médicos cubanos: "deveriam ser parabenizados" 10/09/2013

Médicos cubanos são recepcionados com queijo e doce de leite 16/09/2013

Cubano símbolo do Mais Médicos cuidará de indígenas 25/09/2013

Médicos cubanos fazem sucesso no sertão nordestino 07/10/2013

Médicos cubanos salvaram milhares de vidas na Guatemala 21/10/2013

Dilma pede desculpas a médico cubano hostilizado no Brasil 22/10/2013

Médico cubano no Brasil encante pacientes em posto de saúde 29/10/2013

Médica cubana: "Dilma nos convocou para melhorar saúde do povo" 30/10/2013

Médico brasileiro que atacava cubanos é preso por só bater ponto 07/11/2013

Pacientes do agreste agradecem "de joelhos" chegada de médicos cubanos 11/11/2013

Médicas cubanas "provocam" paz provisória em zona de conflito na Bahia 12/11/2013

Médica cubana utiliza "método diferente" em $1^{\circ}$ dia de trabalho 13/11/2013

Mãe implora por retorno de médico cubano a comunidade 22/11/2013

Por que a população brasileira passou a amar os médicos cubanos? 25/11/2013

Médico cubano afastado volta ao trablaho e é recebido com festa 25/11/2013

A história do médico cubano sabotado por duas médicas brasileiras 29/11/2013

Cubanos trazem ao Brasil uma nova forma de exercer Medicina 02/12/2013 
Os médicos cubanos na visão de um inglês que vive no Brasil 03/12/2013

Médica cubana que completa um mês no Brasil: "falta amor ao próximo" 31/01/2014

Médica cubana que pediu ajuda ao DEM quer encontrar namorado em Miami 06/02/2014

Conselho de Medicina quer que cubanos trabalhem para médicos brasileiros 13/02/2014

Cubana desertora do Mais Médicos tem liminar negada pela justiça 03/03/2014

Casal de cubanos humilhados dá exemplo de solidariedade 03/03/2014

Mais Médicos: 4 mil cubanos chegam ao Brasil nesta semana 06/03/2014

Médica cubana conclui seu plano e consegue asilo nos EUA 03/04/2014

Globo é obrigada a reconhecer qualidade dos médicos cubanos 11/06/2014

\title{
ANEXO 2
}

\section{JURAMENTO DE HIPÓCRATES}

Faculdade de Medicina UFMG

\author{
JURAMENTO DE HIPÓCRATES
}

Prometo que, ao exercer a arte de curar, mostrar-me-ei sempre fiel aos preceitos da honestidade, da caridade e da ciência. Penetrando no interior dos lares, meus olhos serão cegos, minha língua calará os segredos que me forem revelados, o que terei como preceito de honra. Nunca me servirei da minha profissão para corromper os costumes ou favorecer o crime. Se eu cumprir este juramento com fidelidade, goze eu para sempre a minha vida e a minha arte com boa reputação entre os homens; se o infringir ou dele afastar-me, suceda-me o contrário.

(Hipócrates, 450 a.C) 
ANEXO 3

\section{MEDIDA PROVISÓRIA Nº 621, DE 8 DE JULHO DE 2013.}

Institui o Programa Mais Médicos e dá outras providências.

A PRESIDENTA DA REPÚBLICA, no uso da atribuição que lhe confere o art. 62 da Constituição, adota a seguinte Medida Provisória, com força de lei:

\section{CAPÍTULO I DISPOSIÇÕES GERAIS}

Art. 1o

Fica instituído o Programa Mais Médicos, com a finalidade de formar recursos humanos na área médica para o Sistema Único de Saúde - SUS e com os seguintes objetivos:

I - diminuir a carência de médicos nas regiões prioritárias para o SUS, a fim de reduzir as desigualdades regionais na área da saúde;

II - fortalecer a prestação de serviços na atenção básica em saúde no País;

III - aprimorar a formação médica no País e proporcionar maior experiência no campo de prática médica durante o processo de formação;

IV - ampliar a inserção do médico em formação nas unidades de atendimento do SUS, desenvolvendo seu conhecimento sobre a realidade da saúde da população brasileira;

$\mathrm{V}$ - fortalecer a política de educação permanente com a integração ensinoserviço, por meio da atuação das instituições de educação superior na supervisão acadêmica das atividades desempenhadas pelos médicos;

VI - promover a troca de conhecimentos e experiências entre profissionais da saúde brasileiros e médicos formados em instituições estrangeiras;

VII - aperfeiçoar médicos para atuação nas políticas públicas de saúde do País e na organização e funcionamento do SUS; e

VIII - estimular a realização de pesquisas aplicadas ao SUS.

Art. 2o Para consecução dos objetivos do Programa Mais Médicos, serão adotadas, entre outras, as seguintes ações:

I - reordenação da oferta de cursos de medicina e vagas para residência médica, priorizando regiões de saúde com menor relação de vagas e médicos por habitante e com estrutura de serviços de saúde em condições de ofertar campo de prática suficiente e de qualidade para os alunos;

II - estabelecimento de novos parâmetros para a formação médica no País;

e III - promoção, nas regiões prioritárias do SUS, de aperfeiçoamento de médicos na área de atenção básica em saúde, mediante integração ensino-serviço, inclusive por meio de intercâmbio internacional. 


\section{CAPÍtULO II}

\section{DA AUTORIZAÇÃO PARA FUNCIONAMENTO DE CURSOS DE MEDICINA}

Art. 3o A autorização para o funcionamento de curso de graduação em medicina, por instituição de educação superior privada, será precedida de chamamento público, e caberá ao Ministro de Estado da Educação dispor sobre:

I - pré-seleção dos Municípios para a autorização de funcionamento de cursos de medicina, ouvido o Ministério da Saúde;

II - procedimentos para celebração do termo de adesão ao chamamento público pelos gestores locais do SUS;

III - critérios para autorização de funcionamento de instituição de educação superior privada especializada em cursos na área de saúde;

IV - critérios do edital de seleção de propostas para obtenção de autorização de funcionamento de curso de medicina; e

V - periodicidade e metodologia dos procedimentos avaliativos necessários ao acompanhamento e monitoramento da execução da proposta vencedora do chamamento público.

$\S 1$ o Na pré-seleção dos Municípios de que trata o inciso I do caput, deverá ser considerada, no âmbito da região de saúde:

I - a relevância e a necessidade social da oferta de curso de medicina; e

II - a existência, nas redes de atenção à saúde do SUS, de equipamentos públicos adequados e suficientes para a oferta do curso de medicina, incluindo, no mínimo, os seguintes serviços, ações e programas:

a) atenção básica;

b) urgência e emergência;

c) atenção psicossocial;

d) atenção ambulatorial especializada e hospitalar; e

e) vigilância em saúde.

$\S 2$ o Por meio do termo de adesão de que trata o inciso II do caput, o gestor local do SUS compromete-se a oferecer, para a instituição de educação superior vencedora do chamamento público, a estrutura de serviços, ações e programas de saúde necessários para a implantação e para o funcionamento do curso de graduação em medicina.

§ 3o O edital previsto no inciso IV do caput observará, no que couber, a legislação sobre licitações e contratos administrativos, exigirá garantia de proposta do participante, e multa por inexecução total ou parcial do contrato, conforme previsto respectivamente no art. 56 e no inciso II do caput do art. 87 da Lei no 8.666, de 21 de junho de 1993.

$\S 4$ o O disposto neste artigo não se aplica aos pedidos de autorização para funcionamento de curso de medicina protocolados no Ministério da Educação até a data de publicação desta Medida Provisória. 


\section{CAPÍTULO III \\ DA FORMAÇÃO MÉDICA NO BRASIL}

Art. 4o Para os ingressantes nos cursos de medicina a partir de $1^{\circ}$ de janeiro de 2015 , a formação do médico abrangerá dois ciclos distintos e complementares entre si, correspondendo:

I - o primeiro ciclo, à observância das diretrizes curriculares nacionais, com o cumprimento da carga horária não inferior a sete mil e duzentas horas; e

II - o segundo ciclo, a treinamento em serviço, exclusivamente na atenção básica à saúde no âmbito do SUS, com duração mínima de dois anos, conforme regulamentação do Conselho Nacional de Educação - CNE, homologada pelo Ministro de Estado da Educação.

$\S 1$ o O segundo ciclo não dispensa o estudante de medicina do estágio curricular obrigatório de treinamento em serviço supervisionado, em regime de internato, desenvolvido durante o primeiro ciclo do curso e disciplinado em conformidade com as diretrizes curriculares nacionais.

§ 2o Sem prejuízo da necessária supervisão acadêmica a cargo da instituição de educação superior à qual o estudante de medicina esteja vinculado, o segundo ciclo será realizado sob supervisão técnica de médicos, detentores de título de pósgraduação.

§ 3o Durante a realização do segundo ciclo, é assegurada aos estudantes de medicina a percepção de bolsa custeada pelo Ministério da Saúde, em valor estabelecido em ato do Ministro de Estado da Saúde.

Art. 5o Ao estudante de medicina aprovado no primeiro ciclo, conforme certificado expedido pela correspondente instituição de educação superior, será concedida permissão para o exercício profissional da medicina, válida exclusivamente para as atividades do segundo ciclo de formação.

$\S 1$ 1o A inscrição no segundo ciclo de formação é condição necessária e suficiente para expedição da permissão de exercício profissional de que trata o caput pelos Conselhos Regionais de Medicina.§ 2o O segundo ciclo de formação é considerado componente curricular obrigatório do curso de graduação em medicina e será inscrito no histórico escolar do estudante.

§ 3 o O diploma de médico somente será conferido ao estudante de medicina aprovado no segundo ciclo de formação.

§ 4o O segundo ciclo de formação poderá ser aproveitado como uma etapa dos programas de residência médica ou de outro curso de pós-graduação, nos termos definidos pelos Ministérios da Educação e da Saúde, ouvida a Comissão Nacional de Residência Médica - CNRM.

Art. 6o As instituições de ensino superior promoverão a adequação da matriz curricular dos cursos de medicina para atendimento ao disposto nesta Medida Provisória, nos prazos e na forma definida pelo CNE, em parecer homologado pelo Ministro de Estado da Educação.

Parágrafo único. O CNE terá o prazo de cento e oitenta dias, contado da data de publicação desta Medida Provisória, para submeter o parecer referido no caput ao Ministro de Estado da Educação. 


\section{CAPÍTULO IV \\ DO PROJETO MAIS MÉDICOS PARA O BRASIL}

Art. $7^{\circ}$ Fica instituído, no âmbito do Programa Mais Médicos, o Projeto Mais Médicos para o Brasil, que será oferecido:

I - aos médicos formados em instituições de educação superior brasileiras ou com diploma revalidado no País; e

II - aos médicos formados em instituições de educação superior estrangeiras, por meio de intercâmbio médico internacional.

$\S 1$ 1o A seleção e ocupação das vagas ofertadas no âmbito do Projeto Mais Médicos para o Brasil observará a seguinte ordem de prioridade:

I - médicos formados em instituições de educação superior brasileiras ou com diploma revalidado no País;

II - médicos brasileiros formados em instituições estrangeiras com habilitação para exercício da medicina no exterior; e

III - médicos estrangeiros com habilitação para exercício de medicina no exterior.

$\S 2$ o Para fins do Projeto Mais Médicos para o Brasil, considera-se:

I - médico participante - médico intercambista ou médico formado em instituição de educação superior brasileira ou com diploma revalidado; eII - médico intercambista médico formado em instituição de educação superior estrangeira com habilitação para exercício da medicina no exterior.

§ 3o A coordenação do Projeto Mais Médicos para o Brasil ficará a cargo dos Ministérios da Educação e da Saúde, que disciplinarão, por meio de ato conjunto dos Ministros de Estado da Educação e da Saúde, a forma de participação das instituições públicas de educação superior e as regras de funcionamento do Projeto, incluindo a carga horária, as hipóteses de afastamentos e os recessos.

Art. 8o O aperfeiçoamento dos médicos participantes ocorrerá mediante oferta de curso de especialização por instituição pública de educação superior e envolverá atividades de ensino, pesquisa e extensão, que terá componente assistencial mediante integração ensino-serviço.

$\S 1$ o O aperfeiçoamento de que trata o caput terá prazo de até três anos, prorrogável por igual período caso ofertadas outras modalidades de formação, conforme definido em ato conjunto dos Ministros de Estado da Educação e da Saúde.

§ 2o A aprovação do médico participante no curso de especialização será condicionada ao cumprimento de todos os requisitos do Projeto Mais Médicos para o Brasil e à aprovação nas avaliações periódicas.

Art. $9^{\circ}$ Integram o Projeto Mais Médicos para o Brasil:

I - o médico participante, que será submetido ao aperfeiçoamento profissional supervisionado;

II - o supervisor, profissional médico responsável pela supervisão profissional contínua e permanente do médico; e 
III - o tutor acadêmico, docente médico que será responsável pela orientação acadêmica.

$\S 1$ 1o São condições para a participação do médico intercambista no Projeto Mais Médicos para o Brasil, conforme disciplinado em ato conjunto dos Ministros de Estado da Educação e da Saúde:

I - apresentar diploma expedido por instituição de educação superior estrangeira;

II - apresentar habilitação para o exercício da medicina no país de sua formação; e

III - possuir conhecimentos de língua portuguesa.

$\S 20$ Os documentos previstos nos incisos I e II do $\S 1^{\circ}$ sujeitam-se à legalização consular gratuita, dispensada a tradução juramentada, nos termos de ato conjunto dos Ministros de Estado da Educação e da Saúde.

Art. 10. O médico intercambista exercerá a medicina exclusivamente no âmbito das atividades de ensino, pesquisa e extensão do Projeto Mais Médicos para o Brasil, dispensada, para tal fim, a revalidação de seu diploma nos termos do $\S 2^{\circ}$ do art. 48 da Lei no 9.394, de 20 de dezembro de 1996.

$\S 1^{\circ}$ Fica vedado ao médico intercambista o exercício da medicina fora das atividades do Projeto Mais Médicos para o Brasil.

§ 2o Para exercício da medicina pelo médico intercambista no âmbito do Projeto Mais Médicos para o Brasil será expedido registro provisório pelos Conselhos Regionais de Medicina.

§ 3o A declaração de participação do médico intercambista no Projeto Mais Médicos para o Brasil, fornecida pela coordenação do programa, é condição necessária e suficiente para a expedição de registro provisório pelos Conselhos Regionais de Medicina, não sendo aplicável o art. 99 da Lei no 6.815, de 19 de agosto de 1980, e o art. 17 da Lei nº 3.268, de 30 de setembro de 1957.

$\S 4$ o O registro provisório será expedido pelo Conselho Regional de Medicina no prazo de quinze dias, contado da apresentação do requerimento pela coordenação do programa de aperfeiçoamento, e terá validade restrita à permanência do médico intercambista no Projeto Mais Médicos para o Brasil, nos termos do regulamento.

$\S 50 \mathrm{O}$ médico intercambista registrado provisoriamente estará sujeito à fiscalização e ao pagamento das anuidades estabelecidas pelo Conselho Regional de Medicina em que estiver inscrito, conforme legislação aplicável aos médicos inscritos em definitivo.

§ 6o O médico intercambista não participará das eleições do Conselho Regional de Medicina em que estiver inscrito.

Art. 11. As atividades desempenhadas no âmbito do Projeto Mais Médicos para o Brasil não criam vínculo empregatício de qualquer natureza.

Art. 12. O médico intercambista estrangeiro inscrito no Projeto Mais Médicos para o Brasil fará jus ao visto temporário de aperfeiçoamento médico pelo prazo de três anos, prorrogável por igual período em razão do disposto no $\S 1^{\circ}$ do art. $8^{\circ}$, mediante declaração da coordenação do projeto.

$\S 1$ o O Ministério das Relações Exteriores poderá conceder o visto temporário de que trata o caput aos dependentes legais do médico intercambista estrangeiro, incluindo companheiro ou companheira, pelo prazo de validade do visto do titular. 
$\S 20$ Os dependentes legais do médico intercambista estrangeiro poderão exercer atividades remuneradas, com emissão de Carteira de Trabalho e Previdência Social pelo Ministério do Trabalho e Emprego.

§ 30 É vedada a transformação do visto temporário previsto neste artigo em permanente. $\S 40$ Aplicam-se os arts. 30, 31 e 33 da Lei no 6.815, de 1980, ao disposto neste artigo.

Art. 13. Os médicos integrantes do Projeto Mais Médicos para o Brasil poderão perceber bolsas nas seguintes modalidades:

I - bolsa-formação;

II - bolsa-supervisão; e

III - bolsa-tutoria.

$\S 1$ 1o Além do disposto no caput, a União concederá ajuda de custo destinada a compensar as despesas de instalação do médico participante, que não poderá exceder a importância correspondente ao valor de três bolsas-formação.

$\S 2^{\circ}$ Fica a União autorizada a custear despesas com deslocamento dos médicos participantes e seus dependentes legais, conforme dispuser ato conjunto dos Ministros de Estado do Planejamento, Orçamento e Gestão e da Saúde.

§ 3o Os valores das bolsas e da ajuda de custo a serem concedidas e suas condições de pagamento serão definidos em ato conjunto dos Ministros de Estado da Educação e da Saúde.

Art. 14. O médico participante enquadra-se como segurado obrigatório do Regime Geral de Previdência Social - RGPS, na condição de contribuinte individual, na forma da Lei $\mathrm{n}^{\circ}$ 8.212, de 24 de julho de 1991.

Parágrafo único. Ficam ressalvados da obrigatoriedade de que trata o caput os médicos intercambistas:

I - selecionados por meio de instrumentos de cooperação com organismos internacionais que prevejam cobertura securitária específica; ou

II - filiados a regime de seguridade social no seu país de origem, que mantenha acordo internacional de seguridade social com a República Federativa do Brasil.

Art. 15. Poderão ser aplicadas as seguintes penalidades aos médicos participantes do Projeto Mais Médicos para o Brasil que descumprirem o disposto nesta Medida Provisória e nas normas complementares:

I - advertência;

II - suspensão; e

III - desligamento das ações de aperfeiçoamento.

$\S 1$ o Na hipótese do inciso III do caput, poderá ser exigida a restituição dos valores recebidos a título de bolsa, ajuda de custo e aquisição de passagens, acrescidos de atualização monetária, conforme definido em ato conjunto dos Ministros de Estado da Educação e da Saúde.

$\S 20 \mathrm{Na}$ aplicação das penalidades previstas neste artigo, serão consideradas a natureza e a gravidade da infração cometida, assegurados o contraditório e a ampla defesa.

$\S 30$ No caso de médico intercambista, o desligamento do programa implicará o cancelamento do registro provisório e do registro de estrangeiro. 
$\S 4$ o Para fins do disposto no $\S 3^{\circ}$, a coordenação do Projeto Mais Médicos para o Brasil comunicará o desligamento do médico participante ao Conselho Regional de Medicina e ao Ministério da Justiça.

Art. 16. As demais ações de aperfeiçoamento na área de atenção básica em saúde em regiões prioritárias para o SUS, voltadas especificamente para os médicos formados em instituições de educação superior brasileiras ou com diploma revalidado, serão desenvolvidas por meio de projetos e programas dos Ministérios da Saúde e da Educação.

$\S 1$ o As ações de aperfeiçoamento de que trata o caput serão realizadas por meio de instrumentos de incentivo e mecanismos de integração ensino-serviço.

$\S 2$ o Aplica-se o disposto nos arts. 11, 13, 14 e 15 aos projetos e programas de que trata o caput.

\section{CAPÍtULO V DISPOSIÇÕES FINAIS}

Art. 17. Para execução das ações previstas nesta Medida Provisória, os Ministérios da Educação e da Saúde poderão firmar acordos e outros instrumentos de cooperação com organismos internacionais, instituições de educação superior nacionais e estrangeiras, órgãos e entidades da administração pública direta e indireta da União, dos Estados, do Distrito Federal e dos Municípios, consórcios públicos e entidades privadas, inclusive com transferência de recursos.

Art. 18. Ficam transformadas, no âmbito do Poder Executivo, sem aumento de despesa, cento e dezessete Funções Comissionadas Técnicas - FCT, criadas pelo art. 58 da Medida Provisória no 2.229-43, de 6 de setembro de 2001, do nível FCT- 13, em dez cargos em comissão do Grupo-Direção e Assessoramento Superiores - DAS, sendo dois DAS-5 e oito DAS-4.

Art. 19. Ficam os Ministérios da Saúde e da Educação autorizados a contratar, mediante dispensa de licitação, instituição financeira oficial federal para realizar atividades relacionadas aos pagamentos das bolsas de que trata esta Medida Provisória.

Art. 20. Fica a Empresa Brasileira de Serviços Hospitalares - EBSERH autorizada a conceder bolsas para ações de saúde, a ressarcir despesas, a adotar outros mecanismos de incentivo a suas atividades institucionais, e a promover as ações necessárias ao desenvolvimento do Programa Mais Médicos, observada a Lei $\mathrm{n}^{\circ} 12.550$, de 15 de dezembro de 2011.

Art. 21. Poderá ser concedida bolsa para atividades de preceptoria nas ações de formação em serviço nos cursos de graduação e residência médica ofertados pelas instituições federais de educação superior ou pelo Ministério da Saúde.

Art. 22. Os médicos participantes e seus dependentes legais ficarão isentos do pagamento das taxas e emolumentos previstos nos arts. 20, 33 e 131 da Lei no 6.815, de 1980, e no Decreto-Lei no 2.236, de 23 de janeiro de 1985.

Art. 23. Para os efeitos do art. 26 da Lei no 9.250, de 26 de dezembro de 1995, os valores percebidos a título de bolsa prevista nesta Medida Provisória e na Lei no 11.129, de 30 de junho de 2005, não caracterizam contraprestação de serviços. 
Art. 24. O quantitativo dos integrantes dos projetos e programas de aperfeiçoamento de que trata esta Medida Provisória observará os limites dos recursos orçamentários disponíveis.

Parágrafo único. As despesas decorrentes da execução dos projetos e programas previstos nesta Medida Provisória correrão à conta de dotações orçamentárias destinadas aos Ministérios da Educação, da Defesa e da Saúde, consignadas no Orçamento Geral da União.

Art. 25. Os Ministros de Estado da Educação e da Saúde poderão editar normas complementares para o cumprimento do disposto nesta Medida Provisória.

Art. 26. A Lei $\mathrm{n}^{\circ}$ 8.745, de 9 de dezembro de 1993, passa a vigorar com as seguintes alterações:

"Art. 2o

XI - admissão de professor para suprir demandas excepcionais decorrentes de programas e projetos de aperfeiçoamento de médicos na área de atenção básica em saúde em regiões prioritárias para o Sistema Único de Saúde - SUS, mediante integração ensino-serviço, respeitados os limites e as condições fixados em ato conjunto dos Ministros de Estado do Planejamento, Orçamento e Gestão, da Saúde e da Educação.

" (NR)

"Art. $4^{\circ}$

IV - três anos, nos casos das alíneas "h" e "l" do inciso VI e dos incisos VII, VIII e XI do caput do art. $2^{\circ}$ desta Lei;

Parágrafo único.

V - no caso dos incisos VII e XI do caput do art. $2^{\circ}$, desde que o prazo total não exceda seis anos; e ." (NR)

Art. 27. Esta Medida Provisória entra em vigor na data de sua publicação.

Brasília, 8 de julho de 2013; $192^{\circ}$ da Independência e $125^{\circ}$ da República.

\section{DILMA ROUSSEFF}

Aloizio Mercadante

Alexandre Rocha Santos Padilha

Miriam Belchior

Este texto não substitui o publicado no DOU de 9.7.2013.

REPUBLICAÇÃO

MEDIDA PROVISÓRIA Nº 621, DE 8 DE JULHO DE 2013

Institui o Programa Mais Médicos e dá outras providências.

"II - o segundo ciclo, a treinamento em serviço, exclusivamente na atenção básica à saúde e em urgência e emergência no âmbito do SUS, com duração mínima de dois anos, 
conforme regulamentação do Conselho Nacional de Educação - CNE, homologada pelo Ministro de Estado da Educação."

Republicação do inciso II do caput do art. 4o da Medida Provisória $n^{\circ}$ 621, de 8 de julho de 2013, por ter constado incorreção quanto ao original publicado no Diário Oficial da União de 9 de julho de 2013, Seção 1.

Este texto não substitui o publicado no DOU de 9.7.2013 e republicada em 10.7.2013 